\title{
Low-Flow Characteristics
}

\section{of Streams in the}

Mississippi Embayment in

Mississippi and Alabama

By PAUL R. SPEER, HAROLD G. GOLDEN, JAMES F. PATTERSON, and others

With a section on QUALITY OF THE WATER

By W. J. WELBORNE

WATER RESOURCES OF THE MISSISSIPPI EMBAYMENT

GEOLOGICAL SURVEY PROFESSIONAL PAPER 448-I

The magnitude, duration, frequency of recurrence, and chemical composition of low flows

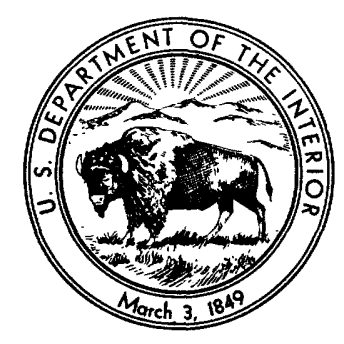

UNITED STATES GOVERNMENT PRINTING OFFICE, WASHINGTON : 1964 
UNITED STATES DEPARTMENT OF THE INTERIOR

STEWART L. UDALL, Secretary

GEOLOGICAL SURVEY

Thomas B. Nolan, Director

The U.S. Geological Survey Library catalog cards for this publication appear after page I 47.

For sale by the Superintendent of Documents, U.S. Government Printing Office Washington, D.C. 20402 


\section{CONTENTS}

Abstract

Introduction

Purpose and scope

Definition of terms

Description of the area

Physiography

Geology . .

Manmade changes ...............

Tombigbee-Black Warrior River basin . . . . . . . . .

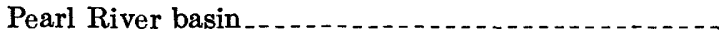

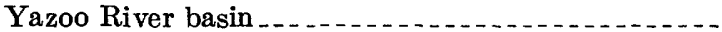

Big Black River basin.

Farm ponds and lakes.......

Low-flow characteristics.

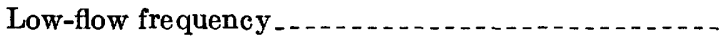

Flow duration

Factors affecting low flow

Eastern Gulf of Mexico

Tombigbee-Black Warrior River basin

\begin{tabular}{|c|c|c|}
\hline Page & & Page \\
\hline I 1 & Factors affecting low flow-Continued & \\
\hline 2 & Eastern Gulf of Mexico basins-Continued & \\
\hline 2 & Pascagoula River basin & I 26 \\
\hline 3 & Pearl River basin & 27 \\
\hline 4 & Tennessee River basin & 27 \\
\hline 4 & Lower Mississippi River basin & 27 \\
\hline 4 & Hatchie River basin & 27 \\
\hline 6 & Wolf River basin & 28 \\
\hline 7 & Yazoo River basin & 28 \\
\hline 7 & Big Black River basin & 30 \\
\hline 8 & Bayou Pierre basin & 30 \\
\hline 8 & Low flows and ground-water fluctuations & 30 \\
\hline 9 & Method of study & 31 \\
\hline 9 & Basic data for the analysis & 31 \\
\hline 9 & Low-flow frequency analysis & 32 \\
\hline 14 & Flow-duration analysis & 33 \\
\hline 21 & Draft-storage relations & 35 \\
\hline 21 & by W. J. Welborne & 38 \\
\hline 24 & nd recommendations $\ldots$ & 45 \\
\hline 24 & Selected references. & 46 \\
\hline
\end{tabular}

\section{ILLUSTRATIONS}

[Plates are in pocket]

Plate 1. Map of the Mississippi embayment in Mississippi and Alabama showing the generalized geology and the 7-day 2-year low flow at gaging stations.

2. Map showing authorized flood-control works, Yazoo-Mississippi basin, Mississippi.

3. Map showing patterns for chemical analyses of low-flow surface waters in the Mississippi embayment in Mississippi and Alabama.

Figure 1. Map of the Mississippi embayment showing areas covered by the four chapters on low-flow characteristics of streams

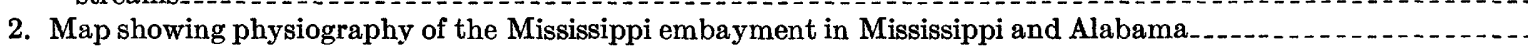

3. Graphs showing magnitude and frequency of annual low flow for Pearl River at Jackson, Miss., 1929-57.....

4. Graph showing flow-duration curve for Pearl River at Jackson, Miss., 1929-57

5. Map of the Mississippi embayment showing areas covered, by parts, for which streamflow records are published in reports on surface-water supply

6. Graphs showing relation of annual low flows and flow duration, Noxubee River at Macon and Pearl River at Jackson, Miss., 1939-57.

7. Graph showing annual low flow for indicated number of days at 10 -year recurrence interval, Sipsey River at Moores Bridge, Ala.

8. Graph showing average release from a volume of storage of 5 acre-feet per square mile for indicated number of days.

9-10. Graphs showing areal draft-storage relations, Mississippi embayment in Mississippi and Alabama:

9. Ten-year recurrence interval

10. Twenty-year recurrence interval 
TABLE 1. Geologic units cropping out in area of study

2. Low-flow characteristics of streams in the Mississippi embayment in Mississippi and Alabama.

3. Magnitude and frequency of annual low flow at daily-record gaging stations in the Mississippi embayment in Mississippi and Alabama........

4. Duration of daily flow at daily-record gaging stations in the Mississippi embayment in Mississippi and Alabama ...

5. Water losses in Luxapalila Creek between Millport, Ala., and Steens, Miss.

6. Lowest mean discharge, Pearl River at Jackson, Miss

7. Duration of daily flow, by water year, Pearl River at Jackson, Miss

8. Seven-day minimum discharges in order of magnitude, Pearl River at Jackson and Noxubee River at Macon, Miss., climatic years 1939-57.

9. Chemical analyses of low-flow surface waters in the Mississippi embayment in Mississippi and Alabama.

10. Source and significance of dissolved mineral constituents and properties of water 


\title{
WATER RESOURCES OF THE MISSISSIPPI EMBAYMENT
}

\section{LOW-FLOW GHARACTERISTICS OF STREAMS IN THE MISSISSIPPI EMBAYMENT IN MISSISSIPPI AND ALABAMA}

\author{
By Paul R. Speer, Harold G. Golden, James F. Patterson, and others
}

\begin{abstract}
The low-flow characteristics of a stream largely govern the type and the economics of its utilization. The magnitude, duration, and frequency of low flows are used both to determine whether a water-utilization project can be operated without storage and, if not, to compute the amount of storage required for its operation. The frequency of low flows affects the economics of both the construction and the operation of a water-utilization project.

The semitropical climate of the Mississippi embayment in Mississippi and Alabama is influenced largely by the warm moist airmasses that move northward from the Gulf of Mexico, and it is characterized by fairly high temperatures, high humidity, and alternate semiannual wet and dry seasons.

The physiography of the area is an expression of the underlying geology, and both exert a major influence on the low flows of the streams, particularly for short periods. For longer periods of low flow, surface runoff from intervening precipitation is included in the low-flow discharges, and the influence of the other factors on the total flow is minimized.
\end{abstract}

Manmade changes to the land and to the drainage patterns have greatly altered the regimen of flow of many streams. The normal operation of four major flood-control reservoirs on the Yazoo River system increases the flow of streams below the reservoirs during June to September. The Yazoo Basin of the Mississippi Alluvial Plain has been subject to more changes by man than any other part of the study area, and the changes have been so extensive that analysis of the low-flow characteristics of streams in the Yazoo Basin is almost impossible.

limited low-flow data, in cubic feet per second per square mile, for 78 daily-record gaging stations and 141 partial-record stations are summarized for ready comparison. If a stream became regulated and if the basic data permitted, both the natural and the regulated flows are included in the results. The summary gives the minimum average 7 - and 30 -day discharges that may be expected to recur at 2- and 10-year intervals, and it gives the flow at the 95- and 90-percent duration points. More detailed data on the magnitude and frequency of low flows and on flow duration, in cubic feet per second, are given for the 78 daily-record gaging stations.

The method used in the analysis has permitted adjusting all gaging-station records of 5 years or more duration to the 29-year reference period 1929-57. For daily-record stations having less than 5 years of record and for the partial-record stations, the results are adjusted to the reference period by relating the observed data to those for a gaging-station record which has previously been adjusted to the reference period.
The base flow of the stream is derived almost entirely from water stored in the ground. The rate at which a stream flows during rainless periods is governed by the amount of ground water in storage and by the rate at which it finds its way to the stream channel. Therefore, the characteristics of the geologic units in and adjacent to the stream channels exert a major influence on the low-flow characteristics.

The 7-day low flows at the 2-year recurrence interval, expressed on a per-square-mile basis, are used to demonstrate areal variations of low flow in the study area. These indices range from 0 to 2.00 cubic feet per second per square mile.

In the Fall Line Hills, streams that are incised through permeable sand and gravel of the Cretaceous System into nearly impermeable pre-Cretaceous rocks and that receive their base flow from the Tuscaloosa Group in the interstream areas have fairly high indices of low flow. On the other hand, streams in the Black Belt which lie within the outcrop areas of the nearly impermeable chalk and clay generally have low indices of base flow that average about 0.008 cubic foot per second per square mile.

In the southern part of the Flatwoods and North Central Plateau, streams receiving flow from the Tuscahoma Sand, from the Nanafalia Formation, and locally from the Naheola Formation show high indices of base flows.

In the extreme northern part of the North Central Plateau, some of the tributaries to the Tallahatchie River, which receive their base flow from the Tallahatta Formation, show indices exceeding 1.00 cubic foot per second per square mile, the highest indices of streams in the study area.

In the north-central part of the area, the McNairy Sand Member of the Ripley Formation is a major contributor to the base flow of the streams.

In the Loess Hills, little or no base flow is derived from sand and gravel in the interstream areas that are covered by loess, probably because the loess is nearly impermeable and prevents appreciable recharge to underlying deposits, which, if exposed, might be prolific aquifers.

Drafts that may be made from specified amounts of storage with a chance of deficiency of once in 10 or 20 years on a longterm average are related to the 7-day 2-year low flow to permit preliminary estimates to be made of the storage required to supplement natural low flows.

Chemical composition of the surface water, as determined from samples collected at 30 sites during low-flow periods, shows that the dissolved solids range from 288 to 11 parts per million. The composition of the water at a particular site commonly 
remains fairly constant during the low-flow period. However, the composition of water in streams draining the same geologic unit may vary considerably at different locations even during the same time period. Differences in the chemical quality of water from different geologic units are too small to serve as a basis for identifying the geologic unit from which a particular stream may be receiving its low flow.

The results of the study suggest fields for further investigation to define additional phases of the hydrologic systems and to determine the effect that manmade changes to the stream systems may have on the low flows of the streams and on the ground-water systems.

\section{INTRODUCTION}

In the Mississippi embayment in Mississippi and Alabama, large supplies of fresh water are available from both surface and underground sources. The area has a high average annual precipitation, and, in addition, both the Mississippi River, on the west side, and the Black Warrior River, on the east side, flow through the area and spill their waters into the Gulf of Mexico. In the past, many parts of the area have been subjected to devastating floods, and much attention has been centered on flood control and drainage. In recent years, however, rapid economic development within the embayment in Mississippi and Alabama has resulted in an increased consumptive use of water, to the extent that serious shortages have occurred during periods of low streamflow. To overcome these deficiencies and to assure the continued economic growth of the area, plans must be made for development and use of the excess flood waters.

The flow characteristics and the chemical, physical, and biological traits of a stream are the basis for its utilization, and these factors exert a major influence on the economics of the stream's development. These characteristics vary with time, with location, and with manmade changes in water and its environment. Of particular significance for utilization of a stream are the magnitude of the low flow, the length of period that a specific discharge continues or is not exceeded, the frequency at which this discharge recurs, and the quality traits of the water during the low-flow periods. The low-flow characteristics included in this report show the amount of water available for utilization without storage and may be used to determine the storage required to provide the minimum flow needed; included also is an indication of the chemical quality of the streams during low flow.

Streamflow records for this report were collected over a period of many years by the U.S. Geological Survey in cooperation with the Mississippi Geological Survey, the Alabama Geological Survey, and, since 1956, the Mississippi Board of Water Commissioners and the Tuscaloosa County Board of Revenue (partialrecord stations in Tuscaloosa County). Other records were obtained through cooperation with the U.S. Army Corps of Engineers and the U.S. Soil Conservation Service. The records were processed by electronic computer in the Washington office of the U.S. Geological Survey under the direction of W. L. Isherwood, hydraulic engineer.

The records were analyzed and the part of this report that concerns streams in the two States was prepared by the following: for Mississippi, H. G. Golden, assisted by John Skelton, under the general direction of W. H. Robinson, district engineer; and for Alabama, J. F. Patterson, assisted by L. B. Peirce, under the general direction of L. E. Carroon, district engineer. Other parts of the report were prepared, the results coordinated and reviewed, and the report assembled by Paul R. Speer, staff engineer. Technical guidance on analytical procedure and format were provided by C. H. Hardison, staff engineer. The report was prepared under the direction of E. M. Cushing. Technical supervision of quality-of-water analyses and preparation of the section of the report on "Quality of the water" were under the direction of M. E. Schroeder, succeeded by J. H. Hubble, district chemist.

The principal authors gratefully acknowledge the assistance of E. M. Cushing, Ernest H. Boswell, and J. G. Newton. They prepared the subsection on "Geology," participated in the field determination of the geologic units that contribute to the low flows of the streams, reviewed the section on "Factors affecting low flow," and offered many helpful suggestions which have been incorporated into the report.

\section{PURPOSE AND SCOPE}

This report is one of a series appraising the water resources of the Mississippi embayment. It presents the low-flow characteristics of streams as defined by the analysis of streamflow records collected at 219 sites in Mississippi and Alabama. Other chapters in this Professional Paper series contain similar data for other parts of the embayment (fig. 1).

The purpose of the current phase of the investigation is to define the hydrologic systems. Because most of the area is underlain by aquifers that yield large quantities of water to wells, ground water is the most readily available source of fresh-water supply in the Mississippi embayment in Mississippi and Alabama. Surface waters are readily available to those users who have access to the streams. In defining the hydrologic systems of the area, ground water and the low flows of the surface water are essentially one water and cannot be separated. The results of the studies on surface water and the results of the studies on ground water, published as separate chapters of this Professional 
Paper series, complement each other in the definition of the hydrologic systems.

The data presented for specific sites consist of (1) frequency data showing the average intervals, in years, between the low discharges for periods of selected length; (2) flow-duration data showing the percentage of the reference period during which the flow equaled or exceeded given rates of flow; and (3) chemical quality of the stream waters at various sites during low flow.

Information on the interval at which low flows of a given magnitude may recur is a prerequisite to the orderly development and utilization of a stream. Such information is essential in the allocation of waters (particularly for consumptive use), in the determination of the recurrence of the flow of waters that are not chemically or physically suitable for specific uses, and in the determination of the economics of storage needed to produce certain minimum flows of acceptable minimum quality. The data in this report will enable designers to determine the magnitude and frequency of low flows at specific sites at the same time that they study the economics of development.

\section{DEFINITION OF TERMS}

Most of the hydrologic terms used in this report are defined by Langbein and Iseri (1960). Other selected terms as used in this report are defined as follows:

Aquifer. A formation, group of formations, or part of a formation that is water bearing.

Climatic year. The year beginning April 1 and ending March 31 of the following calendar year.

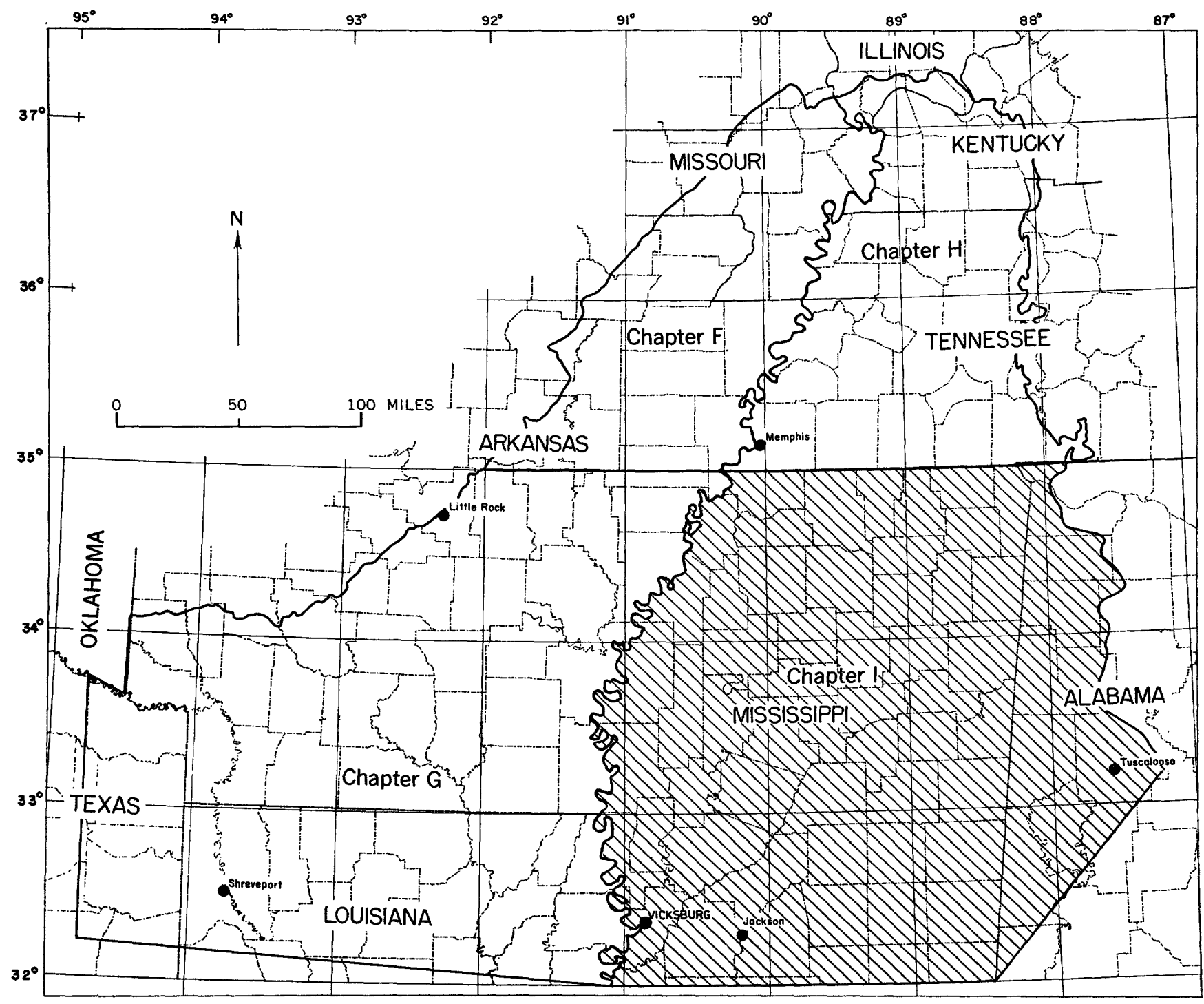

Figure 1.-Map of the Mississippi embayment showing areas covered by the four chapters on low-flow characteristics of streams. The area covered by this chapter is shaded. 
Low-flow frequency curve. A graph showing, as abscissa, the recurrence interval (average return period), in years, at which the lowest mean flow for a selected number of days during a climatic year may be expected to be no greater than a specified discharge, plotted as ordinate.

Median annual 7-day low flow. The annual 7-day low flow having a recurrence interval of 2 years (7-day 2-year) - that is, the mean flow for 7 consecutive days to be expected as an annual minimum 1 year out of 2 , on the average.

Partial-record station. A particular site on a stream at which limited streamflow data, usually consisting of sufficient streamflow measurements to establish a low-flow relation with the daily record at a nearby station, are collected over a period of years for use in hydrologic analyses.

\section{DESCRIPTION OF THE AREA}

The area covered by this report (fig. 1) includes 31,800 square miles in Mississippi and 6,800 square miles in Alabama.

Drainage from the area is primarily to the eastern part of the Gulf of Mexico and to the Mississippi River. The principal rivers draining toward the gulf are the Tombigbee, Pearl, and Pascagoula Rivers. The YazooTallahatchie River system, the Big Black River, and Bayou Pierre are the principal tributaries of the Mississippi River. A small part of the area in the northeast corner drains to the Tennessee River cheifly through Bear Creek.

The stream patterns are extremely irregular and meandering. The channels have flat slopes and are interspersed with abandoned channels and watercourses. In some parts, particularly in the Yazoo Basin and other areas of flat topography, the drainage pattern has been greatly altered by man to facilitate drainage of the land for cultivation.

\section{CLIMATE}

The climate of the area is humid and semitropical. The average annual precipitation ranges from about 48 to 56 inches. Precipitation is nearly all in the form of rain, but snowfall occurs on an average of about twice a year. The warm moist airmasses from the Gulf of Mexico, the dry continental air from the west, and the Atlantic high on the east exert the major influences on the climate. Storms of high intensity, generated in Texas or in the gulf, range northward and follow the natural paths formed by the low ridges and valleys to the northeast. These storms are felt throughout the area but decrease in frequency toward the northwest. Temperatures range from an average low of about $32^{\circ} \mathrm{F}$ in January in the northern part of the area to an average high of about $94^{\circ} \mathrm{F}$ in July in the central Yazoo Basin (fig. 2).

\section{PHYSIOGRAPHY}

The area covered by this report is in the Coastal Plain province and, in general, is an extensive lowland ranging in altitude from about 800 feet to less than 100 feet above sea level. Differential weathering of the underlying deposits has resulted in several physiographic districts typical of the Coastal Plain province (Fenneman, 1938).

Figure 2 shows the principal physiographic districts in the area. These districts include the Fall Line Hills, Black Belt, Pontotoc Ridge and Ripley Cuesta, Flatwoods, North Central Plateau, Buhrstone Cuesta, Jackson Prairie, Southern Pine Hills, Loess Hills, and Yazoo Basin, which is a part of the Mississippi Alluvial Plain.

The Fall Line Hills, in which the topographic characteristics of the inner plateaus and the Coastal Plain intermingle, occupies the eastern periphery of the area from Alabama to the Tennessee line. It composes an area of rugged topography formed on the outcropping resistant sands of the Tuscaloosa Group, the McShan and Eutaw Formations, and the Coffee Sand. The highest altitudes in this area are about 800 feet and decline southwestward toward the Black Belt.

The Black Belt, the topographic expression of the predominant carbonate units of the Selma Group, is a gently rolling to nearly flat terrain whose altitude ranges from 200 to 400 feet. It attains its maximum width in western Alabama and central Mississippi. The district narrows rapidly in northern Mississippi because the Ripley Formation on the west side of the belt becomes sandy and is included in the Pontotoc Ridge and because the Mooreville Chalk on the east grades into the Coffee Sand, which is included in the Fall Line Hills.

The Ripley, Owl Creek, and Clayton Formations underlie the Pontotoc Ridge in northern Mississippi; and the Ripley Formation, Prairie Bluff Chalk, and Clayton Formation underlie the Ripley Cuesta (Chunnennuggee Hills) in Alabama. The ridge and cuesta, whose altitudes are as much as 300 feet higher than those of the Black Belt, are formed primarily on the outcropping sand of the Ripley and on the limestone beds of the Clayton. Between the Pontotoc Ridge and the Ripley Cuesta, the Ripley Formation is similar in lithology to the underlying Demopolis Chalk, and the outcrop area of the Ripley is a part of the Black Belt.

The Flatwoods district is a level belt whose altitude range is about the same as that of the Black Belt. Its maximum width is about 10 miles. It is mostly forested, as the clay soils derived from the underlying Porters Creek Clay are generally not suited for agri- 


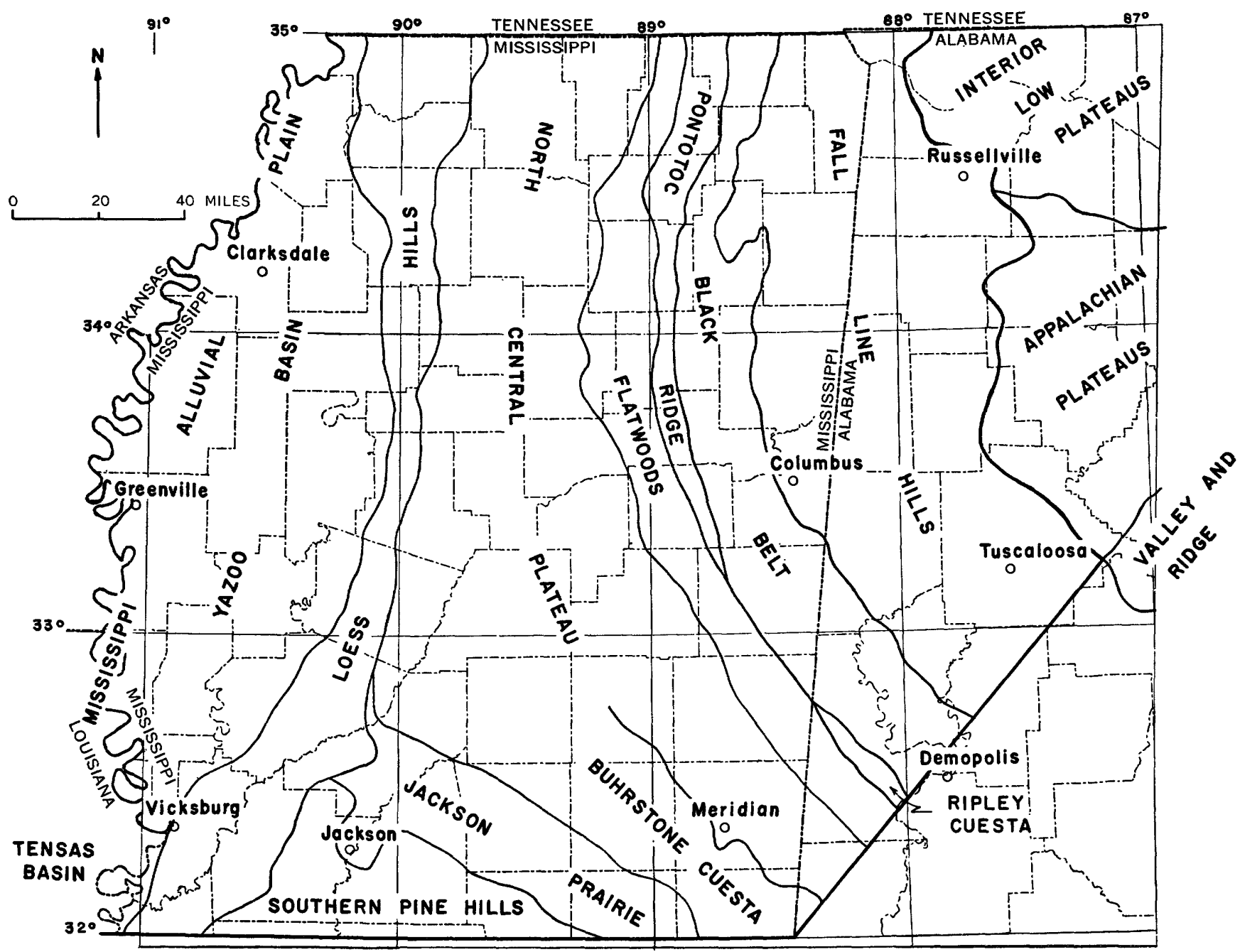

Frgure 2.-Map showing physiography of the Mississippi embayment in Mississippi and Alabama. After Fenneman (1938).

cultural crops. In northern Mississippi the Porters Creek Clay thins, and the Flatwoods belt becomes narrower.

The western margin of the Flatwoods is bordered by the North Central Plateau. This district is formed on the dissected outcrop of the Wilcox and claiborne deposits, which are predominantly sandy. The topography rises to altitudes of more than 700 feet at the inner escarpment and is modified by an entensive terrace development and by loess deposits. Within this belt in east-central Mississippi and western Alabama, there is a line of bills referred to as the Buhrstone Cuesta. This cuesta which forms one of the most rugged terrains in the Coastal Plain, is underlain by the Tallahatta Formation. The Tallahatta includes highly resistant indurated sandstone interbedded with the characteristic claystone of the formation.

The North Central Plateau is bordered on the south by the Jackson Prairie, an area of gently rolling topog- raphy underlain by clay of the Jackson Group. South of the Jackson Prairie is the Southern Pine Hills district. In the embayment part of Mississippi, this district is underlain principally by the Catahoula Sandstone.

A distinctly different physical division, the Loess Hills (Bluff Hills), forms the western border of the North Central Plateau, Jackson Prairie, and Southern Pine Hills districts. The Loess Hills, superimposed on these districts, are the result of the unique erosional characteristics of loess. Where eroded, the loess forms vertical walls, which overlie the steep slopes scoured by the Mississippi River along the eastern side of the alluvial plain. The resulting scarp is a notable physical feature of the Coastal Plain.

The Mississippi Alluvial Plain is the result of aggradation by the Mississippi River and its tributaries. During the last stages of the development of the Mississippi embayment, the Mississippi River cut a 
deep valley into the underlying rocks, which are mostly of Tertiary age, at a time when the sea level was probably relatively much lower than it is at present. The general rise in sea level was accompanied by aggradation of the valley which gradually assumed its present form. The alluvial plain is flat and has an almost imperceptible slope gulfward. Various features such as natural levees, oxbow lakes, abandoned meanders, and alluvial fans occur in the plain. The Mississippi Alluvial Plain is divided into several basins; the Yazoo Basin, known locally as the "Yazoo Delta," 1 and a very small part of the Tensas Basin are in the area of study. The Yazoo Basin occupies all the alluvial plain east of the Mississippi River from the Tennessee line to Vicksburg, Miss.

\section{GEOLOGY}

The area in Mississippi and Alabama covered by this report is a part of the Mississippi embayment and lies within the Coastal Plain. In the geologic past, this region was periodically occupied by the sea and has gradually been filled with sediments ranging in thickness from a few feet to several thousand feet. Within Mississippi and Alabama, units ranging in age from Cretaceous to Quaternary crop out in a modified belted pattern (pl. 1). On the eastern periphery of the area, Paleozoic rocks of the Pennsylvanian and Mississippian Systems crop out. A general description of the geoligic units is given by Cushing and others (1964).

\section{TABLE 1.-Geologic units cropping out in area of study}

\section{MISSISSIPPI}

\section{QUATERNARY SYSTEM}

Alluvium and terrace deposits

Loess

Citronelle Formation

\section{TERTIARY SYSTEM}

Catahoula Sandstone

Vicksburg Group

Forest Hill Sand and Red Bluff Clay

Jackson Group

Yazoo Clay

Moodys Branch Formation

Claiborne Group

Cockfield Formation

Cook Mountain Formation

Sparta Sand

Zilpha Clay

Winona Sand

Tallahatta Formation

Wilcox Formation

1 The Yazoo Basin is inaccurately known locally as the "Yazoo Delta" (Fenneman, 1938, p. 91) or just "the Delta"; but to avoid confusing the reader of this report between the Yazoo Basin and the Yazoo River basin, the name "Yazoo Delta" is used in place of Yazoo Basin.
Midway Group

Naheola Formation

Porters Creek Clay

Clayton Formation

Selma Group

CRETACEOUS SYSTEM

Prairie Bluff Chalk and Owl Creek Formation

Ripley Formation

Demopolis Chalk

Mooreville Chalk and Coffee Sand

Eutaw Fomation

MeShan Formation

Tuscaloosa Group

Gordo Fomation

Coker Formation

Undifferentiated

MISSISSIPPIAN SYSTEM

ALABAMA

QUATERNARY SYSTEM

Alluvium and terrace deposits

Claiborne Group

TERTIARY SYSTEM

Gosport Sand

Lisbon Formation

Tallahatta Formation

Wilcox Group

Hatchetigbee Formation

Tuscahoma Sand

Nanafalia Formation

Midway Group

Naheola Formation

Porters Creek Formation

Clayton Formation

CRETACEOUS SYSTEM

Selma Group

Prairie Bluff Chalk

Ripley Formation

Demopolis Chalk

Mooreville Chalk

Eutaw Formation

MeShan Formation

Tuscaloosa Group

Gordo Formation

Coker Formation

\section{PENNSYLYANIAN SYSTEM}

Pottsville Formation

Table 1 lists the major geologic units. The sand units and the units that include sand members having a wide areal extent contribute most of the water to the low flow of streams within the area. These units include the Coker and Gordo Formations of the Tuscaloosa Group; the MaShan and Eutaw Formations; the Coffee Sand and the Ripley Formation (McNairy Sand Member and Chiwapa Member, respectively) of the Selma Group; the Naheola Formation of the Midway Group; the Wilcox Formation (Mississippi); the Nanafalia Formation and the Tuscahoma Sand of 
the Wilcox Group (Alabama); the Tallahatta Formation, the Winona, Sparta, and Gosport Sands, and the Cockfield Formation of the Claiborne Group; the Forest Hill Sand; the Catahoula Sandstone; the Citronelle Formation; the alluvium; and the terrace deposits.

\section{MANMADE CHANGES}

After the white man started settling the area, he brought about changes that probably have affected the low flows of the streams. These changes can be divided into two groups: (1) those that have been applied to the land in converting it to man's beneficial use, such as irrigation, drainage, land utilization, changes in agricultural crops, and intensity of cultivation, and (2) those that can be classified as changes to the stream systems, such as diversions, development of levees, construction of dams for impounding waters, and changes in stream channels. The effects of some of these changes on the streamflow are interdependent and are difficult to evaluate. Some changes were begun long before records of streamflow were obtained in the area, and still others have been brought about and continued so gradually that, if the effects could be isolated, it would require many subsequent years of record to define them.

At one time or another, most of the area has been under cultivation. Land in some parts of the area was found to be submarginal for agriculture and was permitted to return to the forest state, whereas in other parts, such as the Yazoo Delta, the land has been cultivated intensively for many years.

Many streams in the embayment area in Mississippi and Alabama have been affected by manmade changes. The effects of most of these changes on streamflows are difficult to evaluate quantitatively without collecting special data. For example, the clearing of channels is not a lasting change because of the regrowth of vegetation. Also, the dredging of channels is not a lasting change because of the redeposition of silt in the channel or a further degradation of the channel caused by the change in regime. Attempting to describe or define all the manmade changes that have affected the streamflow in the area is beyond the scope of this report, but some of the major changes that may aid engineering interpretation of the low-flow characteristics are briefly described by river basin in the following paragraphs. Much of this information was obtained from reports of the Corps of Engineers.

\section{TOMBIGBEE-BLACK WAREIOR RIVER BASIN}

Some regulation affecting low flows in the main stems of these streams has existed since the inception of the navigation system as the result of dam closures, leakage, unusual lock manipulation, and use of flash- boards on old dams to maintain pool elevations during periods of low flow. The original locks and dams, Nos. 1-17, were completed by 1915, and since then the major change within the area covered by this report has been the completion of new locks and dams. Tuscaloosa lock and dam eliminated Nos. 10-12 in 1939; Demopolis lock and dam eliminated Nos. 4-7 in August 1954; and Warrior lock and dam eliminated Nos. 8 and 9 in October 1957. Lock and dam 17, completed in 1915, forms Bankhead Lake, which has a usable capacity of 112,000 acre-feet. Warrior lock and dam inundates 7,800 acres.

Since 1915, low flows of the Black Warrior River and of the Tombigbee River below the Black Warrior have been affected by occasional regulation of Bankhead Lake and by regulation at locks and dams along the stream. The closure of the Demopolis lock and dam in August 1954 has adversely affected the computation of the low discharges of the Tombigbee River at Gainesville, Ala., and of the Black Warrior River near Eutaw, Ala., since October 1955.

Channel improvements were completed in 1940 on the East Fork Tombigbee River in Itawamba County, Miss., between Walkers Bridge and the Monroe County line, a distance of 53 miles, and on the West Fork Tombigbee River. The banks were cleared of trees and underbrush, drift jams were removed, channels were enlarged, and 20 cutoff channels, 7 of which were in the reach of the West Fork below Nettleton, Miss., were excavated.

During the period 1940-52, numerous cutoffs and canals were dredged, and existing channels were cleared and snagged on Big Brown, Cane, Chiwapa, Chookatonchee, Coonewar, Donivan, Houlka, Line, Mackys, Mud, Oldtown, and Tibbee Creeks.

During 1922, Luxapalila Creek was canalized in Alabama from Winfield to the Mississippi line, a distance of 50 miles. Before this improvement, the stream was sluggish, and the channel, which was tortuous and snag filled, included numerous sloughs, cutoffs, and wide swampy overflow areas. The old creek channel downstream from the canalized reach slowed the water and caused the lower end of the canal to fill with sand and debris. In 1942, the lower end of the canal was reexcavated, cleared, and snagged, and the channel was improved downstream to the mouth of Yellow Creek. The lower end of the canal has again (1960) filled with alluvial deposits.

Bluff Lake $(1,200$ acres) was formed during 1937 by the construction of a dam on Oktoc Creek, a tributary to the Noxubee River. Prior to this construction, there was a natural diversion of water at all stages from the Noxubee River through Oktoc Creek and back to the main stream. Therefore, Bluff Lake reg- 
ulates the flow of Oktoc Creek and also the part of the flow of Noxubee River that was naturally diverted into Oktoc Creek. The effect of this regulation on the low flows of Noxubee River at Brooksville, Miss. (2B4475), is not known. Studies based on limited data indicate that the regulation of Bluff Lake is not the cause of the periods of no flow in the Noxubee River at the gage; however, the regulation probably does affect the length of these periods.

On Blackburn Fork, a tributary of Locust Fork in Alabama, the entire flow since 1938 has been diverted from 70.1 square miles above Inland Reservoir. The results shown in tables 2-4 for Locust Fork at Trafford, Ala. (2B4555), are computed on the basis of a contributing area of 555 square miles and exclude the area above Inland Reservoir.

\section{PEARL RIVER BASIN}

Canalization of the upper and middle reaches of the Yockanookany River was completed in 1914 and 1928, respectively. The channel is gradually filling at the Kosciusko gage (2B4840), as indicated by the lowwater stages, which were 6 feet higher in 1960 than in 1939. Tuscolameta Creek was canalized from mile 7 to mile 31 in 1924. On September 27, 1961, storage was begun in Ross R. Barnett Reservoir on the Pearl River just downstream from Pelahatchie Creek and upstream from Jackson, Miss. The operation of this water-supply reservoir will modify the low-flow characteristics of Pearl River at and below Jackson (2B4860).

\section{YAZOO RIVER BASIN}

The Yazoo River basin has been affected by more manmade changes than any other basin of comparable size in the area. Approximately half the Yazoo River basin lies in the Yazoo Delta. The first levees were constructed in the early 1800's to protect local areas from Mississippi River floodwaters. This system of levees has gradually been increased in extent and size. Following the major Mississppi River flood of 1927, during which the main levee broke and most of the Yazoo Delta was inundated, the levees were raised, enlarged, and, in some instances, relocated to afford protection against major floods. Since 1928 there has been no flooding of the Yazoo Delta by the Mississippi River except for backwater flooding in the lower Yazoo River area.

The Yazoo Delta is also subject to flooding from the Yazoo River and its tributaries. Nearly 200 drainage districts have been organized over the years to carry out plans for protection from this overflow, and numerous levee systems and channel improvements have been completed.

In recent years the Corps of Engineers, Vicksburg
District, has made numerous channel improvements on Yazoo Delta streams. Plate 2 is a map prepared by the Corps of Engineers, Vicksburg District, to show the completed levees and channel improvements as of July 1, 1959. Also shown on this map are proposed works included in approved plans.

Another major project of the Corps of Engineers to reduce flood damage in the Yazoo Delta was the creation of Sardis, Arkabutla, Enid, and Grenada floodcontrol reservoirs on the major hill tributaries to the Yazoo River system. The location of the reservoirs is shown on plate 2 .

Sardis Reservoir has a storage capacity of $1,570,000$ acre-feet, of which 1,478,000 acre-feet is for flood control and 92,000 acre-feet is for conservation storage. The dam was completed in 1940, and it rises 117 feet above the streambed. The reservoir, when filled to the spillway crest of the dam, forms a lake that is 30 miles long and has a surface area of approximately 90 square miles. The conservation pool is about 10 miles long and has a surface area of 15 square miles.

Arkabutla Reservoir has a storage capacity of 525,300 acre-feet, of which 493,800 acre-feet is for flood control and 31,500 acre-feet is for conservation storage. The dam was completed in June 1943, and it rises 95 feet above the streambed. The reservoir, when filled to the spillway crest of the dam, forms a lake that is 16 miles long and has a surface area of approximately 52 square miles. The conservation pool is 7 miles long and has a surface area of 8 square miles.

Enid Reservoir has a storage capacity of 660,000 acre-feet, of which 602,400 acre-feet is for flood control and 57,600 acre-feet is for conservation storage. The dam was completed in December 1951, and it rises 99 feet above the streambed. The reservoir, when filled to the spillway crest of the dam, forms a lake that is 18 miles long and has a surface area of approximately 42 square miles. The conservation pool is 8 miles long and has a surface area of 10 square miles.

Grenada Reservoir has a storage capacity of $1,337,400$ acre-feet, of which 1,251,700 acre-feet is for flood control and 85,700 acre-feet is for conservation storage. The dam was completed in January 1954, and it rises 102 feet above the streambed. The reservoir, when filled to the spillway crest of the dam, forms a lake that covers approximately 100 square miles and extends 22 miles up the Yalobusha River valley and 19 miles up the Skuna River valley. The conservation pool has a surface area of 15 square miles and is 7 miles long.

The flow characteristics of streams below the four flood-control reservoirs have been altered. The reservoirs control flood discharge in the headwater streams and reduce peak discharges of the Yazoo River. Outflows are regulated from June through September to 
empty the flood-control storage during the low-water season. Thus, normal operation of the reservoirs increases the flow of streams below the reservoirs during June to September of the low-flow period.

The Soil Conservation Service, U.S. Department of Agriculture, has constructed many small flood-water retarding and desilting dams in the Yazoo River basin. Most of these dams have been built since 1956 in the headwaters of small streams in the hill area of the basin. Streams on which five or more structures were complete by June 1960 are the Batupan River and Greasy, Oaklimeter, Persimmon, and Turkey Creeks.

Major channel excavation and clearing projects by the Soil Conservation Service in the Yazoo River basin have included 30 miles of Tallahatchie River in Union County (1951-53), 20 miles of Lappatubby Creek in Union and Pontotoc Counties (about 1954), and 14 miles of Cane Creek in Union and Tippah Counties (1954). The Soil Conservation Service program is continuing in this area, and proposals have been made for 30 structures and for improvements to 80 miles of channel during the next several years.

The Soil Conservation Service, under the authority of Public Law 566, is planning additional flood-control programs in small drainage basins in the Yazoo Delta and in other basins in Mississippi. This program is just beginning to function, and only 11 structures were complete in 3 drainage basins as of June 1960.

Most of the flood-water-retarding structures are built on intermittent streams. In addition to reducing the peak discharge by storing storm runoff, these structures prolong the period of flow of the intermittent streams.

\section{BIG BLACK RIVER BASIN}

Approximately 300 miles of the Big Black River has been improved by the excavation of many cutoffs and by the clearing and snagging of the channel. This project was completed during 1940 . In 1941, clearing and excavation were completed on numerous tributaries to the Big Black River including Peachahala Creek.

\section{FARM PONDS AND LAKES}

The U.S. Department of Agriculture, through the Agricultural Conservation Program, has assisted farmers throughout the area in the creation of farm ponds; since 1940 , more than 53,000 ponds have been created. The average size of the ponds is about $1 \frac{1}{2}$ acres. These ponds may have had some effect on the runoff characteristics downstream, but at low flow the effect is probably negligible.

Lakes have been created in the embayment area of Mississippi by the Mississippi Park Commission and the State Game and Fish Commission. These lakes are:

\begin{tabular}{|c|c|c|c|}
\hline Name of lake & County & $\begin{array}{l}\text { Area, in } \\
\text { acres }\end{array}$ & $\begin{array}{l}\text { Year of con } \\
\text { struction }\end{array}$ \\
\hline Dockery & Hinds.......... & 50 & 1936 \\
\hline Dumas & Tippah_........ & 21 & 1936 \\
\hline Holmes County & Holmes _...... & 12 & 1938 \\
\hline Do & $\ldots$ _. do $\ldots \ldots \ldots$ & 60 & 1958 \\
\hline Tom Bailey _... & Lauderdale _... & 240 & 1959 \\
\hline Monroe & Monroe & 111 & 1958 \\
\hline Roosevelt & Scott $\ldots \ldots \ldots$ & 100 & 1940 \\
\hline Tombigbee & Lee & 100 & 1938 \\
\hline Wall Doxey & Marshall _...... & 60 & 1938 \\
\hline
\end{tabular}

Many lakes have been created by other governmental agencies, private organizations, and individuals; however, information concerning them is not readily available. These small manmade lakes regulate the streamflow from the small basins in which they are located, but the overall effect on the low-flow characteristics probably is negligible.

\section{LOW-FLOW CHARACTERISTICS}

The quantity and quality of streamflow varies with time and place, and this variability has necessitated the collection and interpretation of considerable data in order to appraise the low-flow characteristics of streams in the embayment. Streamflow information used in this report can be divided into two categories: continuous records of flow obtained at daily-record gaging stations, and limited data collected systematically over a period of years at low-flow partial-record stations. Records for 78 daily-record gaging stations and 141 partial-record stations are included in the study of the low-flow characteristics for this report.

So that the low-flow characteristics of one stream could be compared with those of another, all data were adjusted to the common reference period 1929-57. (See section on "Method of study" for further discussion of the reference period.) In the area, 11 dailyrecord gaging stations have complete records for the selected reference period, and 28 other daily-record gaging stations have 18 years or more of record during the reference period. Daily-record stations having less than 5 years of record during this period were designated partial-record stations. Data recorded through 1960 were used to define the low-flow characteristics at partial-record stations.

The average annual precipitation in northern Mississippi from 1900 to 1930 was 51.2 inches, and that from 1931 to 1955 was 51.5 inches. Thus, the average during the reference period was approximately equivalent to that since 1900 . The distribution of precipitation, however, and many other factors influence the quantity and rate of runoff, so that conclusions about streamflow patterns cannot be drawn from precipitation records alone. Some of the outstanding droughts of this century - particularly those of 1943,1954 , and 1956occurred during the reference period. Since 1957, 
streamflow in the report area has not been unusually low.

The low-flow characteristics of all streams analyzed in the study are summarized in table 2. The stations are listed in downstream order by parts corresponding to those used in the annual reports on surface-water supply beginning with the 1951 series (U.S. Geol. Survey, $1951 \mathrm{a}, \mathrm{b}, \mathrm{c})$. The station number is the permanent nationwide number assigned to a station and is used for that station throughout the report. In assigning the numbers, no distinction is made between daily-record stations and partial-record stations. The class of each station is indicated by the letter "D", for a daily-record gaging station, or the letter "P", either for a partial-record station or for a short-term dailyrecord station considered as a partial-record station. The low-flow data shown for each station are the annual minimum 7-day flows having recurrence intervals of 2 and 10 years, the annual minimum 30-day flows having recurrence intervals of 2 and 10 years, and the flows that were equaled or exceeded 90 and 95 percent of the time. For a few of the stations whose records were affected by withdrawals for irrigation during the study period, low-flow data are shown for both natural and regulated conditions. At several of the partial-record stations, three or more of the selected items of the data were zero flow; for these stations, additional flow data are given in footnotes. The daily-discharge station or stations with which each partial-record station was relater are shown in the last column to enable the user of the data to construct the relation curve between the partial-record station and the daily-record gaging station and to interpolate additional data if desired. For a few partial-record stations, it was necessary to construct the relation with other partial-record stations; for each such station, the number of the other station is shown in parentheses.

TaBLe 2.-Low-flow characteristics of streams in the Mississippi embayment in Mississippi and Alabama

LData are adjusted to period $1929-57$ on basis of relation to data at other gaging stations. Class of station: D, daily-record gaging station; $P$, partial-record or short-term dailyrecord station. Figures given for the 7-day 2-year annual low flow are the indices of low flow used in this report]

\begin{tabular}{|c|c|c|c|c|c|c|c|c|c|c|}
\hline \multirow{3}{*}{ Station } & \multirow{3}{*}{ Station name } & \multirow{3}{*}{$\begin{array}{c}\text { Class } \\
\text { of } \\
\text { sta- } \\
\text { tion }\end{array}$} & \multirow{3}{*}{$\begin{array}{l}\text { Drainage } \\
\text { area } \\
\text { (square } \\
\text { miles) }\end{array}$} & \multicolumn{4}{|c|}{$\begin{array}{l}\text { Annual low flow, in cubic feet per second per } \\
\text { square mile, for indicated period of consecutive } \\
\text { days and for indicated recurrence interval, in } \\
\text { years }\end{array}$} & \multirow{2}{*}{\multicolumn{2}{|c|}{$\begin{array}{l}\text { Flow, in cubic feet per } \\
\text { second per square } \\
\text { mile, which was } \\
\text { equaled or exceeded } \\
\text { for indicated percent } \\
\text { of time }\end{array}$}} & \multirow{3}{*}{$\begin{array}{l}\text { Daily-rec- } \\
\text { ord station } \\
\text { with which } \\
\text { partial- } \\
\text { record } \\
\text { station is } \\
\text { correlated 1 }\end{array}$} \\
\hline & & & & \multicolumn{2}{|c|}{ 7-day } & \multicolumn{2}{|c|}{ 30-day } & & & \\
\hline & & & & 2-yr & $10-\mathrm{yr}$ & 2-yr & $10-\mathrm{yr}$ & 90 & 95 & \\
\hline
\end{tabular}

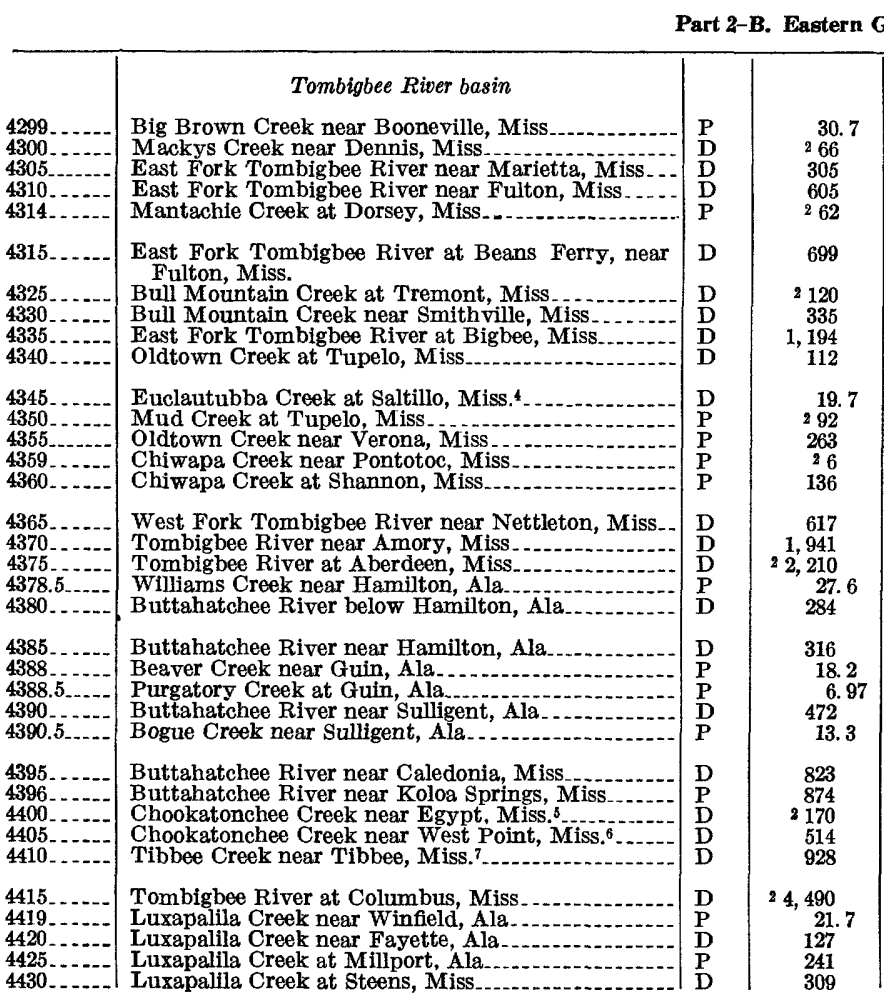

0.01
.26
.11
.07
.02
.07
.13
.13
.09
.001
0
.004
.01
.15
.02
.01
.07
.07
.23
.15
.15
.19
.85
.16
.52
.16
.16
.001
0
0
.07
.19
.33
.24
.16

0.007
.05
.06
.04
$(3)$
.04
.06
.07
.05
0
0
.001
.004
.01
.001
.005
.04
.04
.15
.09
.09
.13
.76
.10
.41
.09
.09
0
0
.05
.13
.24
.17
.09

0.02
.30
.14
.10
.03
.10
.18
.16
.11
.006
0
.009
.02
.23
.04
.02
.09
.09
.28
.19
.19
.23
.89
.20
.56
.20
.20
.007
.003
.002
.09
.23
.39
.29
.20

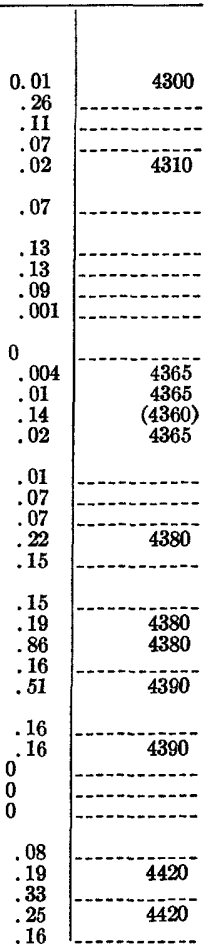

See footnotes at end of table. 
TABLE 2.-Low-flow characteristics of streams in the Mississippi embayment in Mississippi and Alabama-Continued

[Data are adjusted to period $1929-57$ on basis of relation to data at other gaging stations. Class of station: D, daily-record gaging station; $P$, partial-record or short-term dailyrecord station. Figures given for the 7-day 2-year annual low flow are the indices of low flow used in this report]

\begin{tabular}{|c|c|c|c|c|c|c|c|c|c|c|}
\hline \multirow{2}{*}{ Station } & \multirow{2}{*}{ Station name } & \multirow{2}{*}{$\begin{array}{c}\text { Class } \\
\text { of } \\
\text { sta- } \\
\text { tion }\end{array}$} & \multirow{2}{*}{$\begin{array}{l}\text { Drainage } \\
\text { area } \\
\text { (square } \\
\text { miles) }\end{array}$} & \multicolumn{4}{|c|}{$\begin{array}{l}\text { Annual low flow, in cubic feet per second per } \\
\text { square mile, for indicated period of consecutive } \\
\text { days and for indicated recurrence interval, in } \\
\text { years }\end{array}$} & \multicolumn{2}{|c|}{$\begin{array}{l}\text { Flow, in cubic feet per } \\
\text { second per square } \\
\text { mile, which was } \\
\text { equaled or exceeded } \\
\text { for indicated percent } \\
\text { of time }\end{array}$} & \multirow{2}{*}{$\begin{array}{l}\text { Daily-rec- } \\
\text { ord station } \\
\text { with which } \\
\text { partial- } \\
\text { record } \\
\text { station is } \\
\text { correlated 1 }\end{array}$} \\
\hline & & & & $2-\mathrm{yr}$ & $10-\mathrm{yr}$ & $2-\mathrm{yr}$ & $10-\mathrm{yr}$ & 90 & 95 & \\
\hline
\end{tabular}

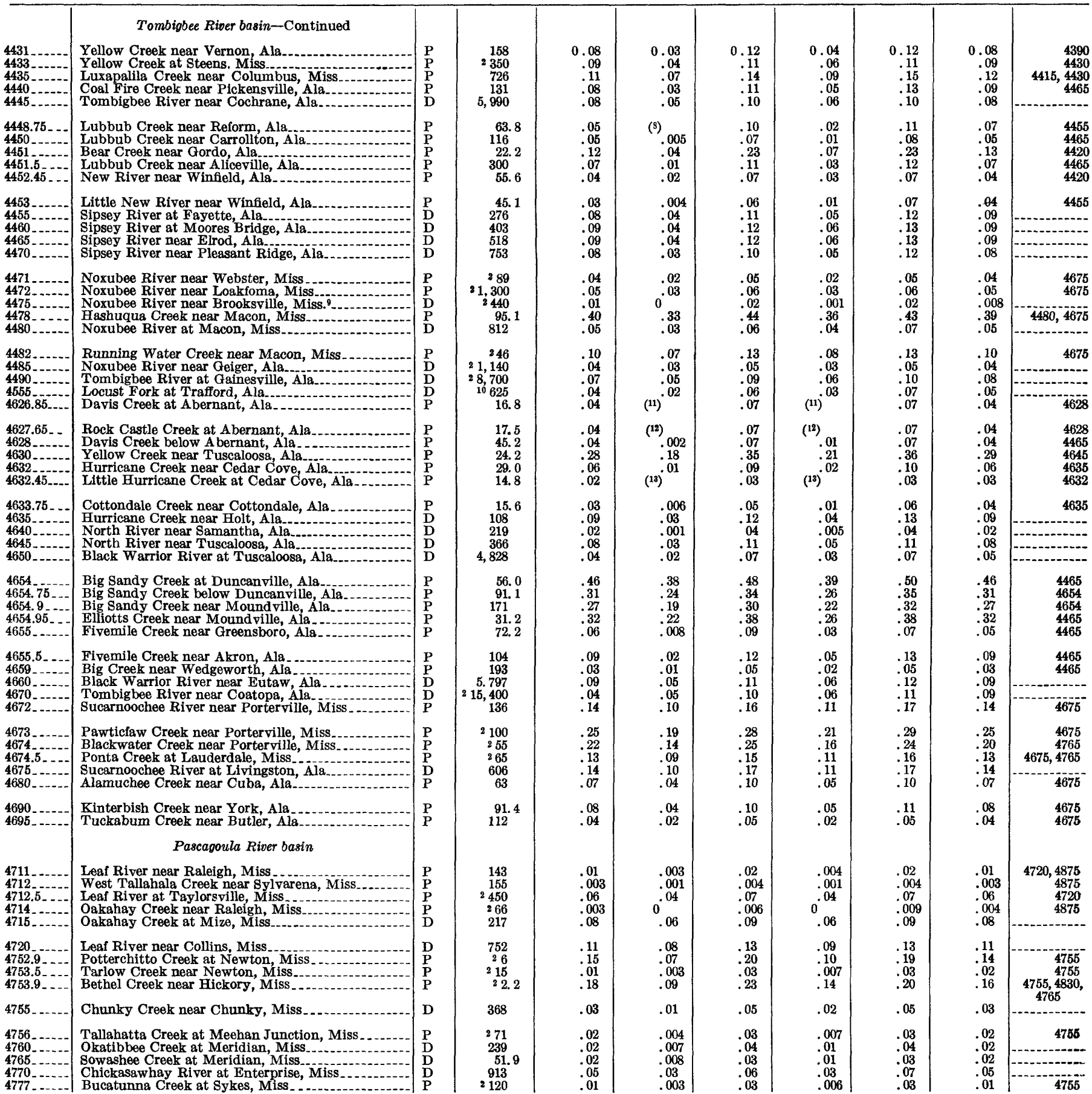

See footnotes at end of table. 
TABLE 2.-Low-flow characteristics of streams in the Mississippi embayment in Mississippi and Alabama-Continued [Data are adjusted to period 1929-57 on basis of relation to data at other gaging stations. Class of station: D, daily-record gaging station; P, partial-record or short-term daily-

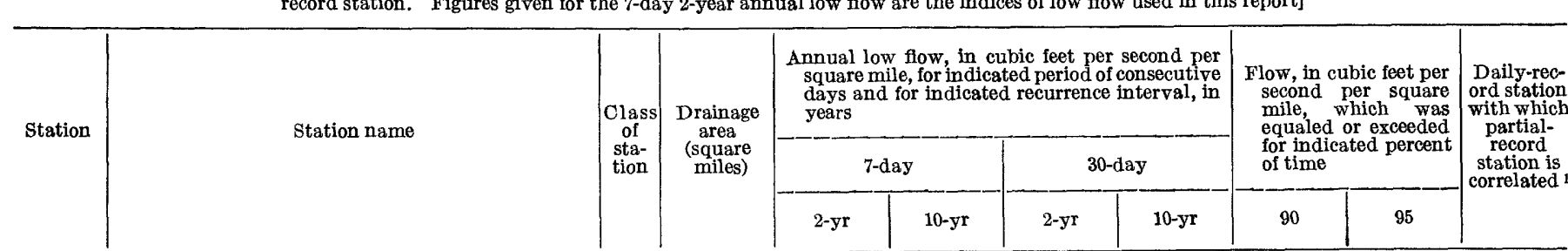

\begin{tabular}{|c|c|}
\hline & Tombigbee River basin-Continued \\
\hline 4778 & Long Creek near Quitman, Miss...... \\
\hline \multirow[t]{2}{*}{4790} & Pascagoula River at Merrill, Miss. \\
\hline & Pearl River basin \\
\hline 4818.8 & Pearl River at Burnside, Miss \\
\hline $\begin{array}{l}4819.3 \\
4819.5\end{array}$ & $\begin{array}{l}\text { Lonsilocka Creek near Philadelphia, Miss. } \\
\text { Kentawka Creek near Philadelphia, Miss.- }\end{array}$ \\
\hline 4820. & Pearl River at Edinburg, Miss \\
\hline 4823 & Lobutcha Creek at Zama, Miss . . \\
\hline 4825 & Lobutcha Creek near Carthage, Miss \\
\hline 4830 & $\begin{array}{l}\text { Tallabogue Creek near Harperville, MisS-..- } \\
\text { Tuscolameta Creek at Walnut Grove, Miss. }\end{array}$ \\
\hline 4835 & Pearl River near Lena, Miss. \\
\hline $4839.5_{-}$ & $\begin{array}{l}\text { Yockanookany River tributary near Kosciusko, } \\
\text { Miss. }\end{array}$ \\
\hline 4840 & Yockanookany River near Kosciusko, Miss. \\
\hline $\begin{array}{l}4845 \\
4850\end{array}$ & Yockanookany River near Ofahoma, Miss-- \\
\hline & Pelahatchie Creek at Pelahatchie, Miss.............. \\
\hline & Pelahatchie Creek near Fannin, Miss. ${ }^{4}$ \\
\hline 4860 & Pearl River at Jackson, Miss \\
\hline 4863 & Richland Creek near Jackson, Miss. . \\
\hline & Rhodes Creek near Terry, Miss..... \\
\hline 4873 & Strong River near Puckett, Miss..... \\
\hline $\begin{array}{l}4874 . \\
4875\end{array}$ & Campbell Creek at Johns, Miss.-. \\
\hline 4875 & $\begin{array}{l}\text { Strong River at Dlo, Miss, } \\
\text { Mill Creek at Braxton, Miss }\end{array}$ \\
\hline
\end{tabular}

art 2-B. Eastern Gulf of Mexico basins-Continued

\begin{tabular}{|c|c|c|c|c|c|c|c|c|}
\hline $\mathbf{P}$ & 75 & 0.05 & 0.02 & 0.07 & 0.02 & 0.07 & 0.04 & $(4777), 4755$, \\
\hline D & 26,600 & .19 & .13 & .21 & .14 & .22 & .18 & 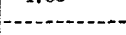 \\
\hline $\begin{array}{l}\mathrm{P} \\
\mathrm{P} \\
\mathrm{P} \\
\mathrm{D} \\
\mathrm{P}\end{array}$ & $\begin{array}{l}524 \\
215 \\
135 \\
898 \\
145\end{array}$ & $\begin{array}{l}.004 \\
.02 \\
.02 \\
.01 \\
.006\end{array}$ & $\begin{array}{l}.001 \\
.007 \\
.007 \\
.005 \\
0\end{array}$ & $\begin{array}{l}.006 \\
.03 \\
.03 \\
.02 \\
.01\end{array}$ & $\begin{array}{l}.002 \\
.01 \\
.01 \\
.007 \\
.001\end{array}$ & $\begin{array}{l}.007 \\
.03 \\
.03 \\
.02 \\
.02\end{array}$ & $\begin{array}{l}.004 \\
.02 \\
.02 \\
.01 \\
.008\end{array}$ & $\begin{array}{r}4820 \\
4820 \\
4820 \\
4825\end{array}$ \\
\hline $\begin{array}{l}\mathrm{D} \\
\mathrm{P} \\
\mathrm{D} \\
\mathrm{D} \\
\mathrm{P}\end{array}$ & $\begin{array}{r}313 \\
240 \\
411 \\
1,995 \\
215\end{array}$ & $\begin{array}{l}.04 \\
.01 \\
.02 \\
.04 \\
.003\end{array}$ & $\begin{array}{l}.03 \\
.002 \\
.01 \\
.02 \\
0\end{array}$ & $\begin{array}{l}.06 \\
.02 \\
.03 \\
.05 \\
.007\end{array}$ & $\begin{array}{l}.03 \\
.005 \\
.01 \\
.03 \\
.001\end{array}$ & $\begin{array}{l}.06 \\
.01 \\
.03 \\
.05 \\
.007\end{array}$ & $\begin{array}{l}.05 \\
.008 \\
.02 \\
.04 \\
.004\end{array}$ & 4830 \\
\hline $\begin{array}{l}\mathrm{D} \\
\mathrm{D} \\
\mathrm{D} \\
\mathrm{P} \\
\mathrm{D}\end{array}$ & $\begin{array}{c}314 \\
484 \\
2,780 \\
72.7 \\
205\end{array}$ & $\begin{array}{l}.03 \\
.03 \\
.05 \\
.004 \\
.004\end{array}$ & $\begin{array}{l}.01 \\
.02 \\
.03 \\
0 \\
0\end{array}$ & $\begin{array}{l}.04 \\
.04 \\
.06 \\
.01 \\
.01\end{array}$ & $\begin{array}{l}.02 \\
.02 \\
.03 \\
0 \\
0\end{array}$ & $\begin{array}{l}.04 \\
.04 \\
.06 \\
.003 \\
.003\end{array}$ & $\begin{array}{l}.03 \\
.03 \\
.05 \\
.001 \\
0\end{array}$ & 4855 \\
\hline $\begin{array}{l}\mathrm{D} \\
\mathrm{P} \\
\mathrm{P} \\
\mathrm{P}\end{array}$ & $\begin{array}{r}23,100 \\
128 \\
20.9 \\
20.8\end{array}$ & $\begin{array}{l}.05 \\
.009 \\
.003 \\
.01\end{array}$ & $\begin{array}{l}.03 \\
.005 \\
.005\end{array}$ & $\begin{array}{l}.06 \\
.01 \\
.004 \\
.01\end{array}$ & $\begin{array}{c}.03 \\
.006 \\
.005\end{array}$ & $\begin{array}{l}.06 \\
.01 \\
.005 \\
.01\end{array}$ & $\begin{array}{l}.05 \\
.009 \\
.003 \\
.01\end{array}$ & $\begin{array}{r}4875 \\
4875 \\
4875,2905\end{array}$ \\
\hline $\mathbf{P}$ & ${ }^{2} 190$ & .01 & .008 & .02 & .01 & .02 & .01 & 4875 \\
\hline $\begin{array}{l}\mathbf{P} \\
\mathbf{D} \\
\mathbf{P}\end{array}$ & $\begin{array}{c}215 \\
429 \\
11.3\end{array}$ & $\begin{array}{l}.03 \\
.06 \\
.03\end{array}$ & $0^{.02}$ & $\begin{array}{l}.03 \\
.07 \\
.009\end{array}$ & $0^{.02}$ & $\begin{array}{l}.03 \\
.07 \\
.01\end{array}$ & $\begin{array}{l}.03 \\
.06 \\
.006\end{array}$ & 4875 \\
\hline
\end{tabular}

Part 3-B. Tennessee River basin

\begin{tabular}{|c|c|c|c|c|c|c|c|c|c|c|}
\hline $\begin{array}{l}5918 \\
5920 \\
5921 \\
5923 \\
5923\end{array}$ & $\begin{array}{l}\text { Tennessee River basin } \\
\text { Bear Creek near Hackleburg, Ala } \\
\text { Bear Creek near Red Bay, Ala } \\
\text { Bear Creek near Tishomingo, Miss. } \\
\text { Cedar Creek near Pleasant Site, Ala } \\
\text { Little Bear Creek near Halltown, Ala }\end{array}$ & $\begin{array}{l}\mathbf{P} \\
\mathbf{P} \\
\mathbf{P} \\
\mathbf{P}\end{array}$ & $\begin{array}{c}143 \\
263 \\
2330 \\
189 \\
78.2\end{array}$ & $\begin{array}{r}0.06 \\
.13 \\
.11 \\
.04 \\
.11\end{array}$ & 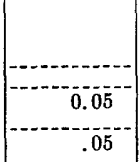 & $\begin{array}{r}0.09 \\
.16 \\
.15 \\
.07 \\
.15\end{array}$ & $\begin{array}{l}0.03 \\
.08 \\
.07 \\
.02 \\
.07\end{array}$ & $\begin{array}{l}0.09 \\
.16 \\
.15 \\
.07 \\
.15\end{array}$ & $\begin{array}{r}0.06 \\
.12 \\
.11 \\
.04 \\
.11\end{array}$ & $\begin{array}{l}5925 \\
5918 \\
5925 \\
5925 \\
5925\end{array}$ \\
\hline $\begin{array}{l}5925 . \\
5925.5 \\
5927 . \\
5927.5\end{array}$ & $\begin{array}{l}\text { Bear Creek at Bishop, Ala } \\
\text { Cripple Deer Creek near Tishomingo, Miss. } \\
\text { Yellow Creek Drainage Canal at Burnsville, Miss } \\
\text { Little Yellow Creek Drainage Canal near Burns- }\end{array}$ & $\begin{array}{l}\mathrm{D} \\
\mathrm{P} \\
\mathrm{P} \\
\mathrm{P}\end{array}$ & $\begin{array}{c}667 \\
210 \\
46.3 \\
15.4\end{array}$ & $\begin{array}{l}.08 \\
.02 \\
.002 \\
.10\end{array}$ & $\stackrel{(3)}{0}^{.03}$ & $\begin{array}{l}.11 \\
.03 \\
.004 \\
.14\end{array}$ & $\begin{array}{c}(3) .05 \\
.002 \\
.08\end{array}$ & $\begin{array}{l}.11 \\
.03 \\
.005 \\
.13\end{array}$ & $\begin{array}{l}.08 \\
.02 \\
.003 \\
.10\end{array}$ & $\begin{array}{l}5928 \\
5928 \\
5928\end{array}$ \\
\hline $5928 \ldots$ & Yellow Creek near Doskie, Miss. & $\mathbf{D}$ & 143 & .11 & .07 & .13 & .08 & .13 & .10 & \\
\hline
\end{tabular}

Part 7. Lower Mississippi River basin

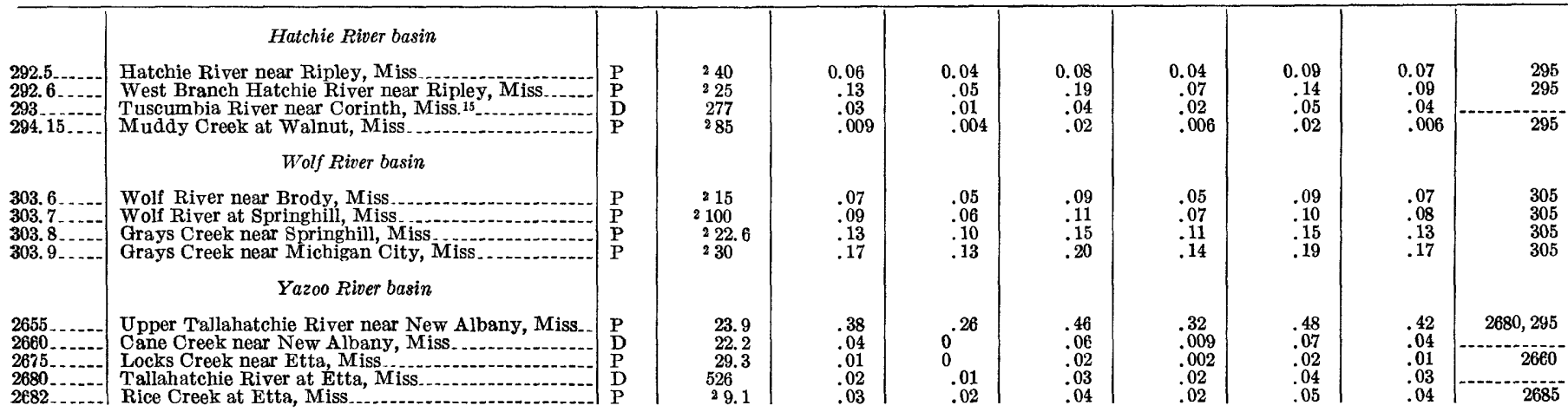


TABLE 2.-Low-flow characteristics of streams in the Mississippi embayment in Mississippi and Alabama-Continued

[Data are adjusted to period 1929-57 on basis of relation to data at other gaging stations. Class of station: D, daily-record gaging station; $P$, partial-record or short-term daily. record station. Figures given for the 7-day 2-year annual low flow are the indices of low flow used in this report]

\begin{tabular}{|c|c|c|c|c|c|c|c|c|c|c|}
\hline \multirow[t]{2}{*}{ Station } & \multirow[t]{2}{*}{ Station name } & \multirow{2}{*}{$\begin{array}{c}\text { Class } \\
\text { of } \\
\text { sta- } \\
\text { tion }\end{array}$} & \multirow{2}{*}{$\begin{array}{c}\text { Drainage } \\
\text { area } \\
\text { (square } \\
\text { miles) }\end{array}$} & \multicolumn{4}{|c|}{$\begin{array}{l}\text { Annual low flow, in cublic feet per second per } \\
\text { square mile, for indicated period of consecutive } \\
\text { days and for indicated recurrence interval, in } \\
\text { years }\end{array}$} & \multicolumn{2}{|c|}{$\begin{array}{l}\text { Flow, in cubic feet per } \\
\text { second per square } \\
\text { mile, which was } \\
\text { equaled or exceeded } \\
\text { for indicated percent } \\
\text { of time }\end{array}$} & \multirow{2}{*}{$\begin{array}{l}\text { Daily-rec- } \\
\text { ord station } \\
\text { with which } \\
\text { partial- } \\
\text { record } \\
\text { station is } \\
\text { correlated } 1\end{array}$} \\
\hline & & & & 2-yr & $10-\mathrm{yr}$ & 2-yr & $10-\mathrm{yr}$ & 90 & 85 & \\
\hline
\end{tabular}

Part 7. Lower Mississippi River basin-Continued

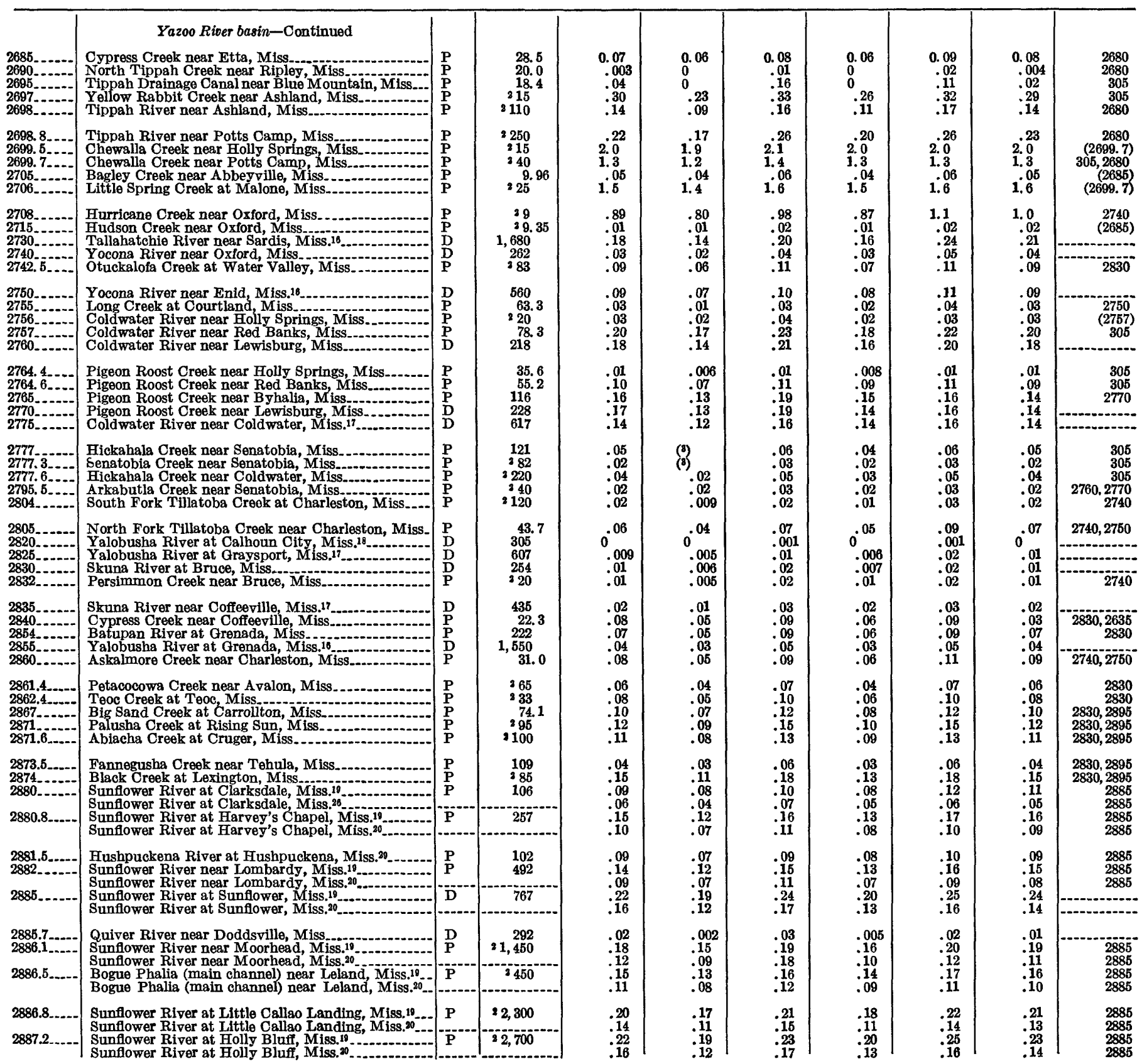

See footnotes at end of table. 
TABLE 2.-Low-flow characteristics of streams in the Mississippi embayment in Mississippi and Alabama-Continued

[Data are adjusted to period 1929-57 on basis of relation to data at other gaging stations. Class of station: D, daily-record gaging station; P, partial-record or short-term dailyrecord station. Figures given for the 7-day 2-year annual low flow are the indices of low flow used in this report]

\begin{tabular}{|c|c|c|c|c|c|c|c|c|c|c|}
\hline \multirow{3}{*}{ Station } & \multirow{3}{*}{ Station name } & \multirow{3}{*}{$\begin{array}{c}\text { Class } \\
\text { of } \\
\text { sta- } \\
\text { tion }\end{array}$} & \multirow{3}{*}{$\begin{array}{c}\text { Drainage } \\
\text { area } \\
\text { (square } \\
\text { miles) }\end{array}$} & \multicolumn{4}{|c|}{$\begin{array}{l}\text { Annual low flow, in cubic feet per second per } \\
\text { square mile, for indicated period of consecutive } \\
\text { days and for indicated recurrence interval, in } \\
\text { years }\end{array}$} & \multirow{2}{*}{\multicolumn{2}{|c|}{$\begin{array}{l}\text { Flow, in cubic feet per } \\
\text { second per square } \\
\text { mile, which was } \\
\text { equaled or exceeded } \\
\text { for indicated percent } \\
\text { of time }\end{array}$}} & \multirow{3}{*}{$\begin{array}{l}\text { Daily-rec- } \\
\text { ord station } \\
\text { with which } \\
\text { partial- } \\
\text { record } \\
\text { station is } \\
\text { correlated } 1\end{array}$} \\
\hline & & & & \multicolumn{2}{|c|}{ 7-day } & \multicolumn{2}{|c|}{ 30-day } & & & \\
\hline & & & & $2-\mathrm{yr}$ & 10-yr & $2-\mathrm{yr}$ & 10-yr & 90 & 95 & \\
\hline
\end{tabular}

\begin{tabular}{|c|c|c|c|c|c|c|c|c|c|c|}
\hline & Big Black River basin & & & & & & & & & \\
\hline 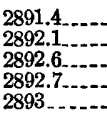 & $\begin{array}{l}\text { Calabrella Creek near Tomnolen, Miss } \\
\text { Big Bywy Ditch near Mathiston, Miss.......... } \\
\text { Big Black River near Vaiden, Miss..... } \\
\text { Hays Creek near Vaiden, Miss } \\
\text { Peachahala Creek near Vaiden, Miss. }\end{array}$ & $\begin{array}{l}\mathrm{P} \\
\mathrm{P} \\
\mathrm{P} \\
\mathrm{P} \\
\mathrm{P}\end{array}$ & $\begin{array}{l}245 \\
215 \\
809 \\
280 \\
245\end{array}$ & $\begin{array}{l}0.05 \\
.007 \\
.03 \\
.006 \\
.002\end{array}$ & $\begin{array}{l}0.03 \\
0 \\
.01 \\
.002\end{array}$ & $\begin{array}{l}0.06 \\
.01 \\
.03 \\
.01 \\
.004\end{array}$ & $\begin{array}{l}0.04 \\
.007 \\
.02 \\
.002\end{array}$ & $\begin{array}{l}0.07 \\
.02 \\
.04 \\
.01 \\
.005\end{array}$ & $\begin{array}{l}0.05 \\
.008 \\
.03 \\
.006 \\
.002\end{array}$ & $\begin{array}{r}4840,2740 \\
4840 \\
2895 \\
2895 \\
(2892.7),\end{array}$ \\
\hline $\begin{array}{l}2893.5 \\
2895 \ldots \\
2895.3 \\
289.3 . \\
2900 . \\
\ldots\end{array}$ & 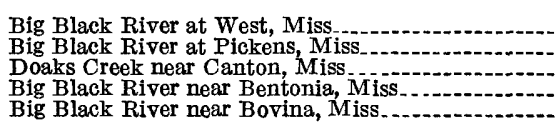 & $\begin{array}{l}\mathrm{P} \\
\mathrm{D} \\
\mathrm{P} \\
\mathrm{D} \\
\mathrm{D}\end{array}$ & $\begin{array}{r}985 \\
21,460 \\
22,340 \\
22,810\end{array}$ & $\begin{array}{l}.02 \\
.04 \\
.07 \\
.05 \\
.04\end{array}$ & $\begin{array}{l}.009 \\
.03 \\
.06 \\
.03 \\
.03\end{array}$ & $\begin{array}{l}.03 \\
.05 \\
.07 \\
.06 \\
.05\end{array}$ & $\begin{array}{l}.01 \\
.03 \\
.06 \\
.03 \\
.03\end{array}$ & $\begin{array}{l}.04 \\
.06 \\
.08 \\
.06 \\
.06\end{array}$ & $\begin{array}{l}.02 \\
.04 \\
.07 \\
.04 \\
.04\end{array}$ & $\begin{array}{r}2895 \\
-4845,2895 \\
\end{array}$ \\
\hline 2905 & 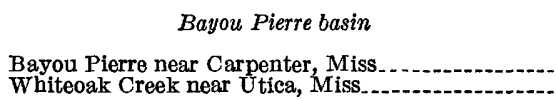 & $\stackrel{\mathrm{D}}{\mathrm{P}}$ & $\begin{array}{r}371 \\
2160\end{array}$ & $\begin{array}{l}.07 \\
.008\end{array}$ & .05 & $\begin{array}{l}.09 \\
.009\end{array}$ & $\begin{array}{l}.05 \\
.006\end{array}$ & $\begin{array}{l}.08 \\
.01\end{array}$ & $\begin{array}{l}.06 \\
.008\end{array}$ & \\
\hline
\end{tabular}

1 Station numbers shown in parentheses are partial-record stations.

2 Approximate.

3 Relation curve not defined in this range.

4 7-day $Q_{1.2}=0.02 ; 15$-day $Q_{1.2}=0.02 ; 30$-day $Q_{1.2}=0.03 ; 60$-day $Q_{1.2}=0.10$.

5 15-day $Q_{2}=0.002$.

67 -day $Q_{1.2}=0.01 ; 15$-day $Q_{1.2}=0.02 ; 30$-day $Q_{1.2}=0.03$.

7 7-day $Q_{1.2}=0.009 ; 15$-day $Q_{1.2}=0.01$.

8 Discharge for 7-day $Q_{10}$ not defined; 15-day $Q_{10}=0.005$

9 Partly regulated by Bluff Lake; pattern of regulation nearly constant since at least 1948.

${ }^{10}$ Includes $70 \mathrm{sq}$ mi of noncontributing area upstream from Inland Reservoir on Blackburn Fork.

11 Discharge for 7-day and 30-day $Q_{10}$ not defined; 60-day $Q_{10}=0.03 ; 120$-day $Q_{10}=0.07$.

12 Discharge for 7-day and 30-day $Q_{10}$ not defined; 60-day $Q_{10}=0.03 ; 120$-day $Q_{10}=0.06$.
13 Discharge for 7-day and 30-day $Q_{10}$ not defined; 60-day $Q_{10}=0.007 ; 120$-day $Q_{10}=0.03$.

14 15-day $Q_{2}=0.005 ; 60$-day $Q_{2}=0.02$.

15 Data not to base period; based on observed data 1950-57 and on records for nearby gaging stations.

16 Data for natural conditions prior to operation of reservoir upstream.

17 Data for natural conditions; site now inundated by reservo
18 -day $Q_{2} .2=0.007 ; 15$-day $Q_{1.2}=0.01 ; 30$-day $Q_{1.2}=0.02$.
19

20 Data for regulated conditions resulting from irrigation withdrawals.

The low-flow data in table 2 are presented in cubic feet per second per square mile to permit direct comparison of flows of streams with different size drainage areas. It should not be inferred, however, that the yield is uniform throughout a drainage basin. On the contrary, the low-flow yields usually differ between tributary streams within a drainage basin and within reaches on a single stream.

The location of the stations in table 2 is shown on plate 1. The station numbers shown in the figure are the same as those used in table 2, except that the first digit is added to indicate the part in which the station is located, and the subdivision of the part is indicated by a letter in the second place. For example, station 2B4299 is in Part 2-B.

\section{LOW-FLOW FREQUENCY}

Low-flow frequency data for 78 daily-record gaging stations in the Mississippi embayment are presented in table 3.

Similar data for the partial-record stations have not been computed because of the limited basic information available at these sites. The data in table 3 can be plotted on graph paper similar to that used in figure 3

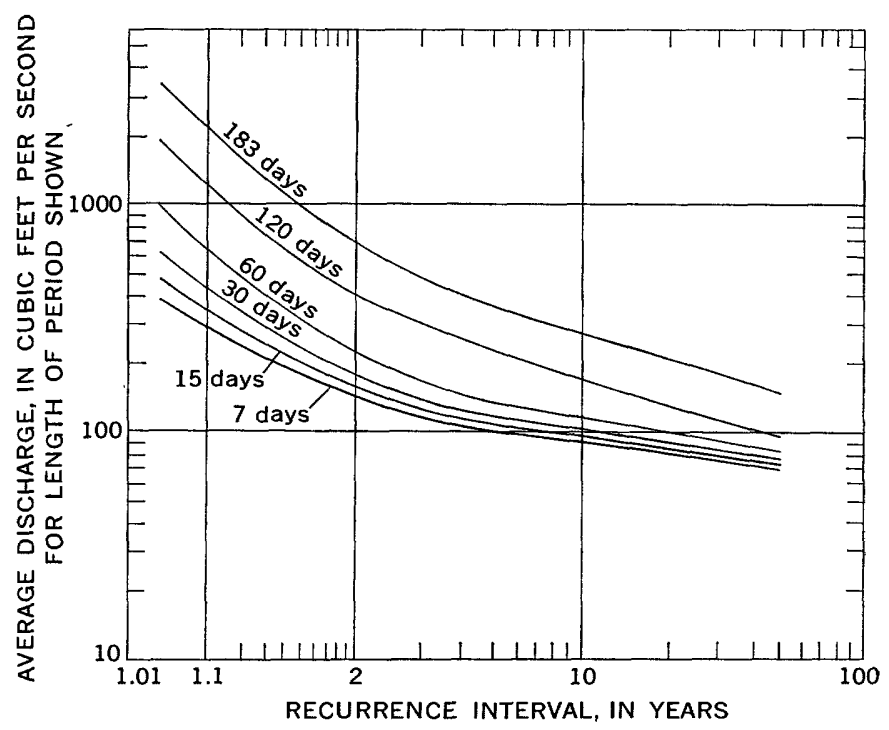

FIgURE 3.-Graphs showing magnitude and frequency of annual low flow for Pearl River at Jackson, Miss., 1929-57. 
if a graphical presentation is desired. The data in table 3 can be used to estimate the probable future magnitude and frequency of low flows at the indicated locations provided no appreciable climatological or manmade changes occur upstream. The probability of occurrence is given in terms of the average time interval between indicated low flows. For example, the lowest average discharge for 7 consecutive days on the Tombigbee River at Columbus, Miss. (2B4415), may be equal to or less than 204 cfs (cubic feet per second) at average intervals of 10 years on a long-term basis. The chance of occurrence in any year is 1 in 10, or 10 percent. These recurrence intervals are averages and do not imply any regularity of recurrence. During the period 1929-60, the 7-day minimum flow at Columbus was less than $204 \mathrm{cfs}$ (the 10-year event) in 1943,1954 , and 1956. Thus, during the 31-year period, the 10-year event occurred 3 times, which is in close agreement with the probable frequency. The intervals between these occurrences, however, are 11 and 2 years, which demonstrates that there was not a regularity of recurrence.

TABLE 3.-Magnitude and frequency of annual low flow at daily-record gaging stations in the Mississippi embayment in Mississippi and Alabama

[Data are adjusted to period April 1929-March 1958 on basis of relation to data at other gaging stations]

\begin{tabular}{|c|c|c|c|c|c|c|c|c|c|c|}
\hline \multirow{2}{*}{ Station } & \multirow{2}{*}{ Station name } & \multirow{2}{*}{$\begin{array}{c}\text { Drainage } \\
\text { area } \\
\text { (sq mi) }\end{array}$} & \multirow{2}{*}{$\begin{array}{c}\text { Period } \\
\text { (consec- } \\
\text { utive } \\
\text { days) }\end{array}$} & \multicolumn{7}{|c|}{$\begin{array}{l}\text { Annual low flow, in cubic feet per second, for indicated recurrence } \\
\text { interval, in years }\end{array}$} \\
\hline & & & & 1.03 & 1.2 & 2 & 5 & 10 & 20 & 50 \\
\hline
\end{tabular}

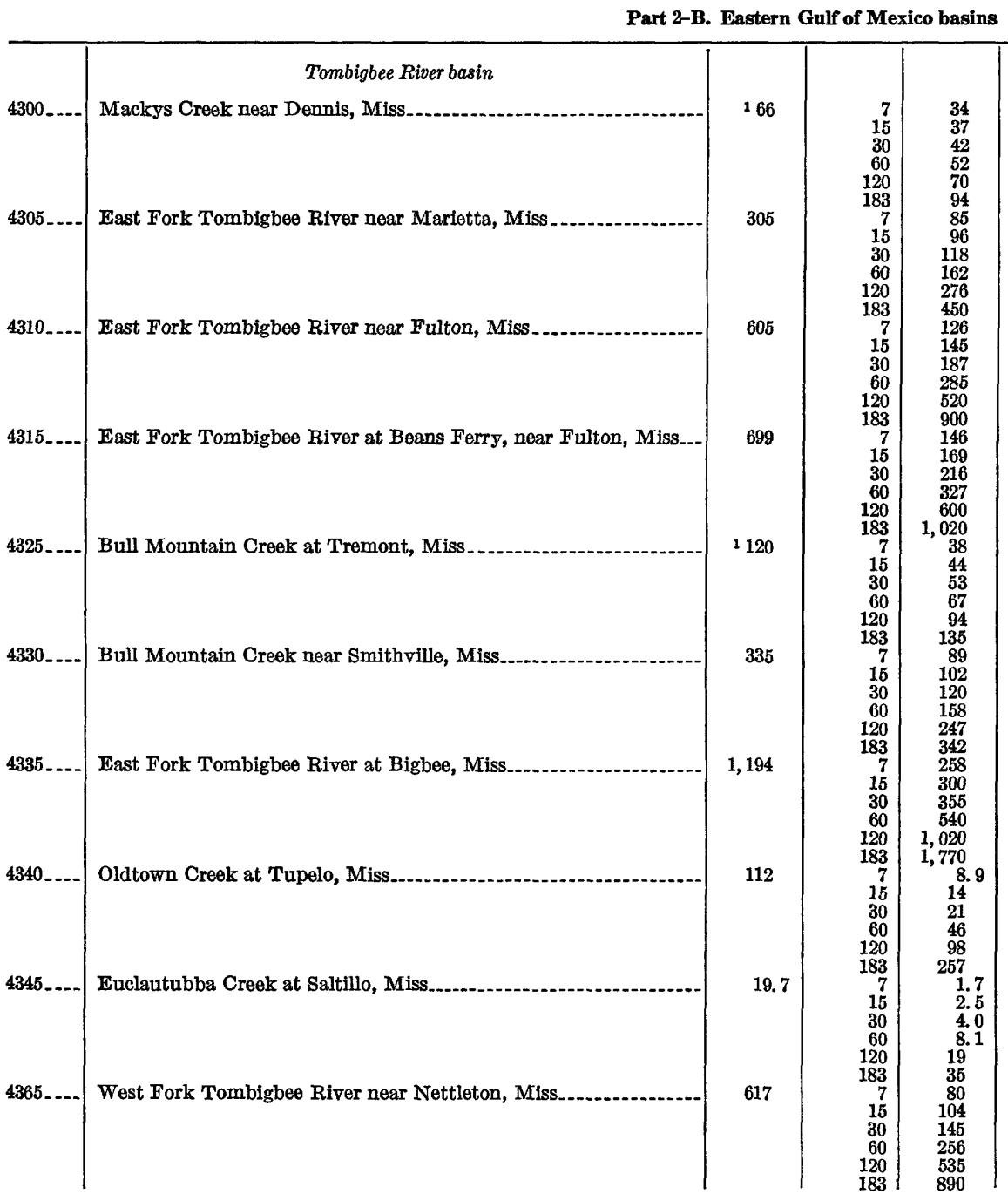

\begin{tabular}{c|} 
\\
\\
25 \\
27 \\
30 \\
37 \\
49 \\
65 \\
54 \\
60 \\
72 \\
95 \\
146 \\
222 \\
75 \\
85 \\
104 \\
148 \\
248 \\
400 \\
86 \\
98 \\
120 \\
168 \\
283 \\
465 \\
26 \\
30 \\
35 \\
45 \\
58 \\
82 \\
64 \\
72 \\
84 \\
108 \\
150 \\
206 \\
162 \\
182 \\
215 \\
293 \\
486 \\
780 \\
1.2 \\
1.8 \\
3.8 \\
8.3 \\
27 \\
71 \\
.3 \\
.4 \\
.6 \\
6.9 \\
13 \\
25 \\
31 \\
41 \\
91 \\
210 \\
390 \\
\end{tabular}

\begin{tabular}{c|c|} 
\\
\\
17 \\
18 \\
20 \\
24 \\
32 \\
43 \\
34 \\
38 \\
44 \\
56 \\
76 \\
110 \\
44 \\
50 \\
58 \\
75 \\
116 \\
178 \\
51 \\
58 \\
68 \\
87 \\
133 \\
207 \\
16 \\
18 \\
21 \\
29 \\
36 \\
51 \\
42 \\
47 \\
54 \\
68 \\
87 \\
118 \\
105 \\
118 \\
134 \\
167 \\
240 \\
350 \\
.1 \\
.1 \\
.7 \\
1.4 \\
5.4 \\
14 \\
0 \\
0 \\
0 \\
.3 \\
1.2 \\
3.4 \\
8.7 \\
11 \\
24 \\
60 \\
126 \\
\end{tabular}

\begin{tabular}{c|} 
\\
\\
\\
12 \\
13 \\
15 \\
17 \\
23 \\
31 \\
24 \\
26 \\
30 \\
38 \\
50 \\
70 \\
30 \\
33 \\
38 \\
47 \\
68 \\
102 \\
34 \\
38 \\
44 \\
55 \\
79 \\
198 \\
9.6 \\
11 \\
13 \\
19 \\
24 \\
35 \\
29 \\
32 \\
36 \\
46 \\
58 \\
80 \\
76 \\
83 \\
94 \\
112 \\
153 \\
210 \\
0 \\
0 \\
.2 \\
.4 \\
1.1 \\
2.8 \\
0 \\
0 \\
0 \\
0 \\
.2 \\
4.7 \\
5.4 \\
6.8 \\
10 \\
20 \\
39
\end{tabular}

\begin{tabular}{c|} 
\\
\\
10 \\
11 \\
12 \\
14 \\
19 \\
26 \\
19 \\
21 \\
24 \\
30 \\
40 \\
56 \\
23 \\
26 \\
30 \\
37 \\
54 \\
80 \\
27 \\
30 \\
35 \\
43 \\
62 \\
92 \\
7.3 \\
8.5 \\
10 \\
14 \\
20 \\
29 \\
24 \\
26 \\
29 \\
38 \\
49 \\
68 \\
61 \\
68 \\
76 \\
90 \\
125 \\
172 \\
0 \\
0 \\
.1 \\
.2 \\
.5 \\
1.3 \\
0 \\
0 \\
0 \\
0 \\
0 \\
.2 \\
3.2 \\
3.8 \\
4.8 \\
7.0 \\
12 \\
23 \\
\end{tabular}

\begin{tabular}{c|c} 
& \\
& \\
8.4 & \\
9.2 & 6.6 \\
10 & 7.2 \\
12 & 8.1 \\
16 & 9.6 \\
21 & 13 \\
15 & 17 \\
17 & 11 \\
19 & 12 \\
24 & 14 \\
33 & 18 \\
46 & 25 \\
18 & 35 \\
21 & 13 \\
24 & 15 \\
29 & 18 \\
43 & 22 \\
63 & 31 \\
21 & 46 \\
24 & 16 \\
28 & 17 \\
34 & 20 \\
49 & 25 \\
72 & 36 \\
5.6 & 54 \\
6.5 & 4.0 \\
7.6 & 4.6 \\
11 & 5.5 \\
16 & 7.8 \\
24 & 12 \\
19 & 19 \\
22 & 17 \\
24 & 19 \\
31 & 24 \\
42 & 35 \\
58 & 48 \\
50 & 39 \\
56 & 43 \\
62 & 48 \\
74 & 58 \\
102 & 79 \\
142 & 110 \\
0 & 0 \\
0 & 0 \\
0 & 0 \\
.1 & .1 \\
.3 & .2 \\
.8 & 0.4 \\
0 & 0 \\
0 & 0 \\
0 & 0 \\
0 & 0 \\
0 & 0 \\
.1 & 0 \\
2.3 & 1.5 \\
2.8 & 1.8 \\
3.5 & 2.2 \\
5.0 & 3.2 \\
16 & 5.6 \\
& 10 \\
\hline
\end{tabular}

See footnotes at end of table. 
TABLE 3.-Magnitude and frequency of annual low flow at daily-record gaging stations in the Mississippi embayment in Mississippi and Alabama-Continued

[Data are adjusted to period April 1929-March 1958 on basis of relation to data at other gaging stations]

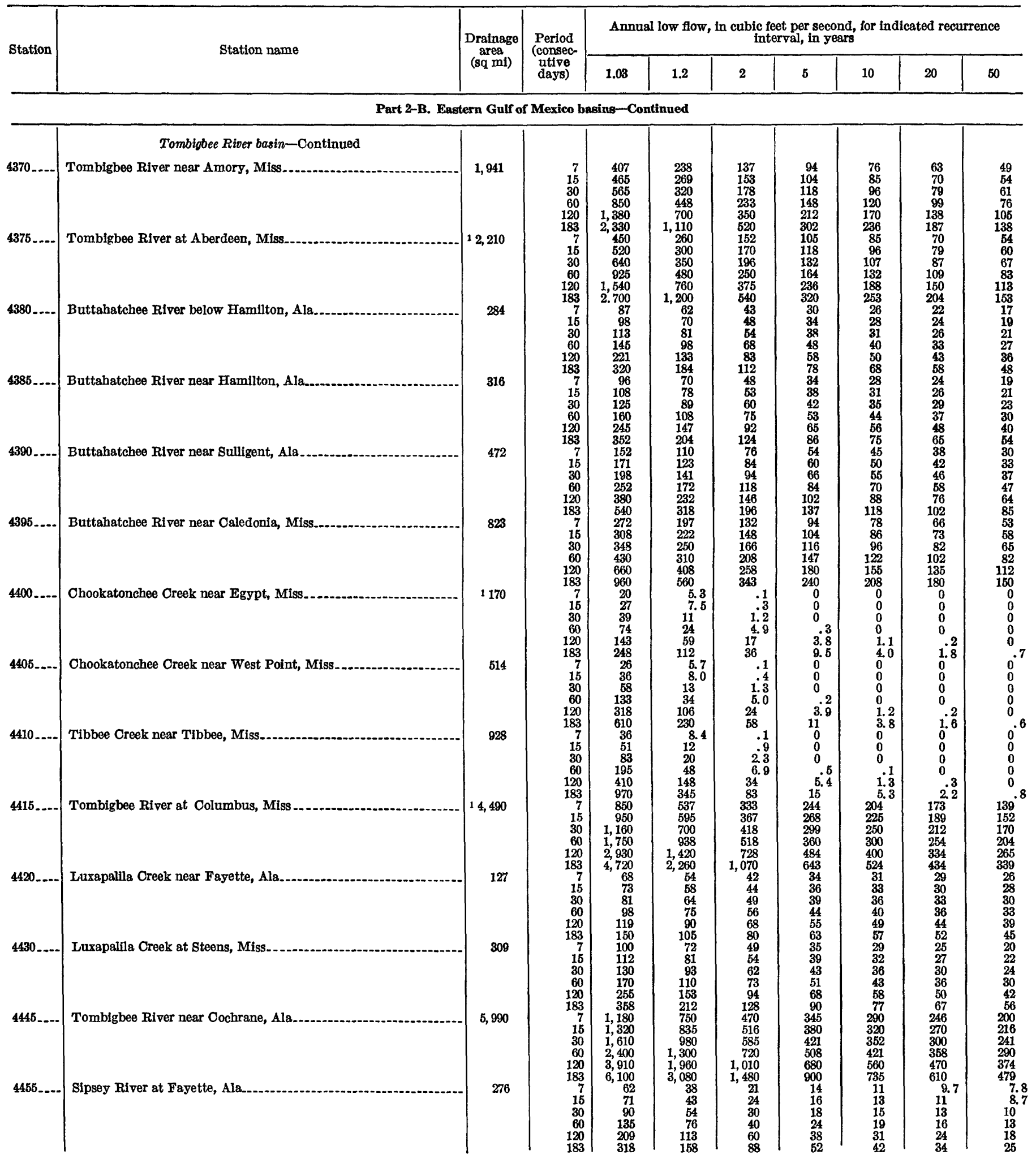

See footnotes at end of table. 
TABLE 3.-Magnitude and frequency of annual low flow at daily-record gaging stations in the Mississippi embayment in Mississippi and Alabama-Continued

[Data are adjusted to period April 1929-March 1958 on basis of relation to data at other gaging stations]

\begin{tabular}{|c|c|c|c|c|c|c|c|c|c|c|}
\hline \multirow{2}{*}{ Station } & \multirow{2}{*}{ Station name } & \multirow{2}{*}{$\begin{array}{c}\text { Drainage } \\
\text { area } \\
\text { (sq mi) }\end{array}$} & \multirow{2}{*}{$\begin{array}{c}\text { Period } \\
\text { (consec- } \\
\text { utive } \\
\text { days) }\end{array}$} & \multicolumn{7}{|c|}{$\begin{array}{c}\text { Annual low flow, in cubic feet per second, for indicated recurrence } \\
\text { interval, in years }\end{array}$} \\
\hline & & & & 1.03 & 1.2 & 2 & 5 & 10 & 20 & 50 \\
\hline
\end{tabular}

Part 2-B. Eastern Gulf of Mexico basins-Continued

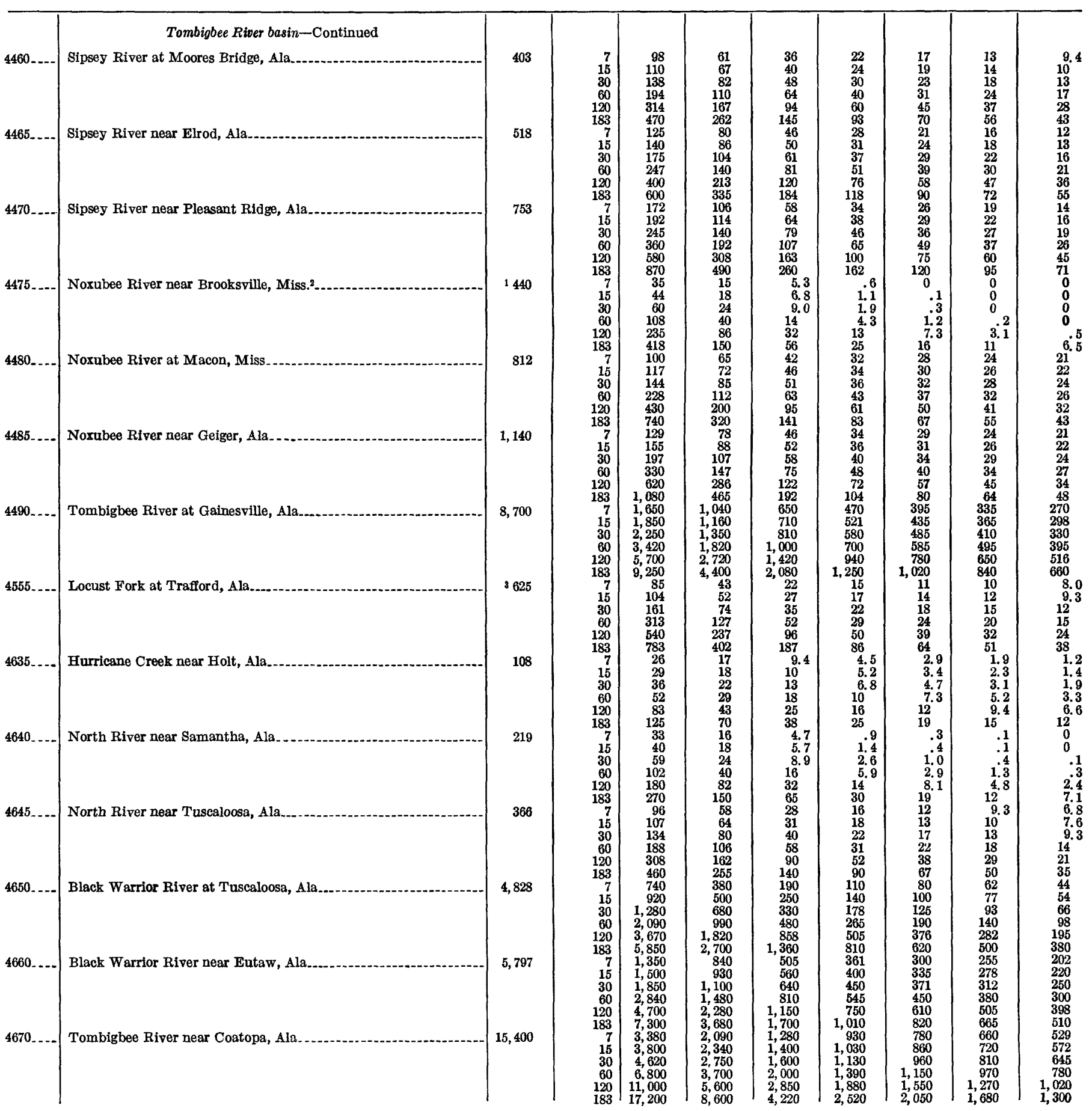

See footnotes at end of table. 
TABLE 3.-Magnitude and frequency of annual low flow at daily-record gaging stations in the Mississippi embayment in Mississippi and Alabama-Continued

[Data are adjusted to period April 1929-March 1958 on basis of relation to data at other gaging stations]

\begin{tabular}{|c|c|c|c|c|c|c|c|c|c|c|}
\hline \multirow{2}{*}{ Station } & \multirow{2}{*}{ Station name } & \multirow{2}{*}{$\begin{array}{c}\text { Drainage } \\
\text { area } \\
\text { (sq mi) }\end{array}$} & \multirow{2}{*}{$\begin{array}{c}\text { Period } \\
\text { (consec- } \\
\text { utive } \\
\text { days) }\end{array}$} & \multicolumn{7}{|c|}{$\begin{array}{l}\text { Annual low flow, in cubic feet per second, for indicated recurrence } \\
\text { interval, in years }\end{array}$} \\
\hline & & & & 1.03 & 1.2 & 2 & $\mathbf{5}$ & 10 & 20 & 50 \\
\hline
\end{tabular}

Part 2-B. Eastern Gulf of Mexico basing-Continued

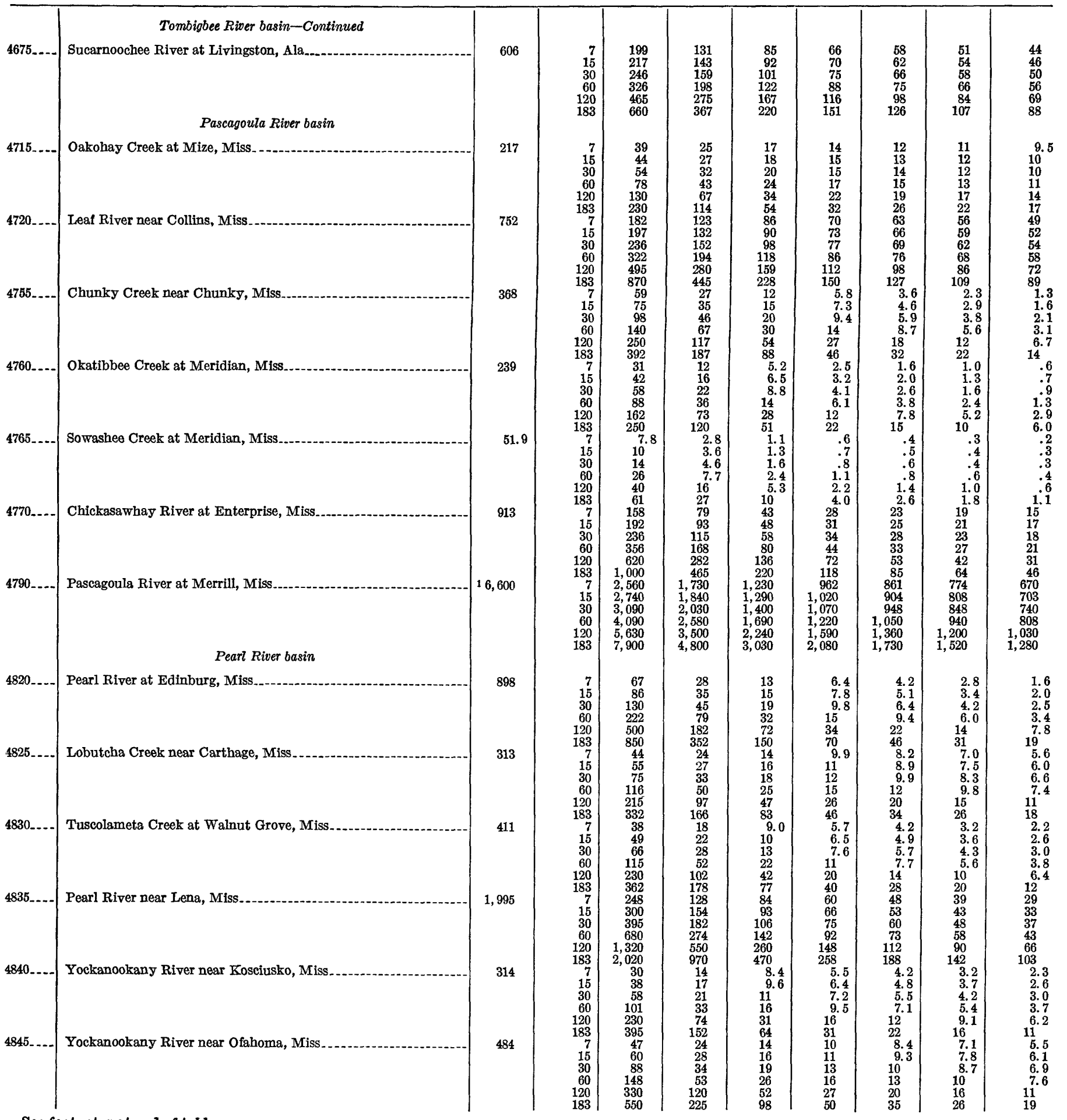

See footnotes at end of table. 
TABLE 3.-Magnitude and frequency of annual low flow at daily-record gaging stations in the Mississippi embayment in Mississippi and Alabama-Continued

[Data are adjusted to period April 1929-March 1958 on basis of relation to data at other gaging stations]

\begin{tabular}{|c|c|c|c|c|c|c|c|c|c|c|}
\hline \multirow{2}{*}{ Station } & \multirow{2}{*}{ Station name } & \multirow{2}{*}{$\begin{array}{c}\text { Drainage } \\
\text { area } \\
\text { (sq mi) }\end{array}$} & \multirow{2}{*}{$\begin{array}{l}\text { Period } \\
\text { (consec- } \\
\text { utive } \\
\text { days) }\end{array}$} & \multicolumn{7}{|c|}{$\begin{array}{l}\text { Annual low flow, in cubic feet per second, for indicated recurrence } \\
\text { interval, in years }\end{array}$} \\
\hline & & & & 1.03 & 1.2 & 2 & 5 & 10 & 20 & 50 \\
\hline
\end{tabular}

Part 2-B. Eastern Gulf of Mexico basins-Continued

\begin{tabular}{|c|c|c|c|c|c|c|c|c|c|c|}
\hline & Pearl River basin-Continued & & & & & & & & & \\
\hline
\end{tabular}

Part 3-B. Tennessee River basin

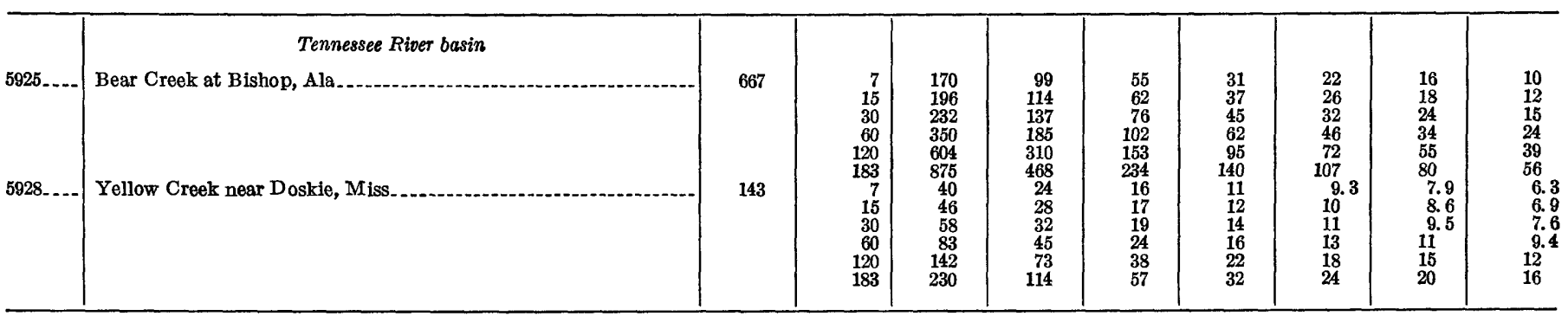

Part 7. Lower Mississippi River basin

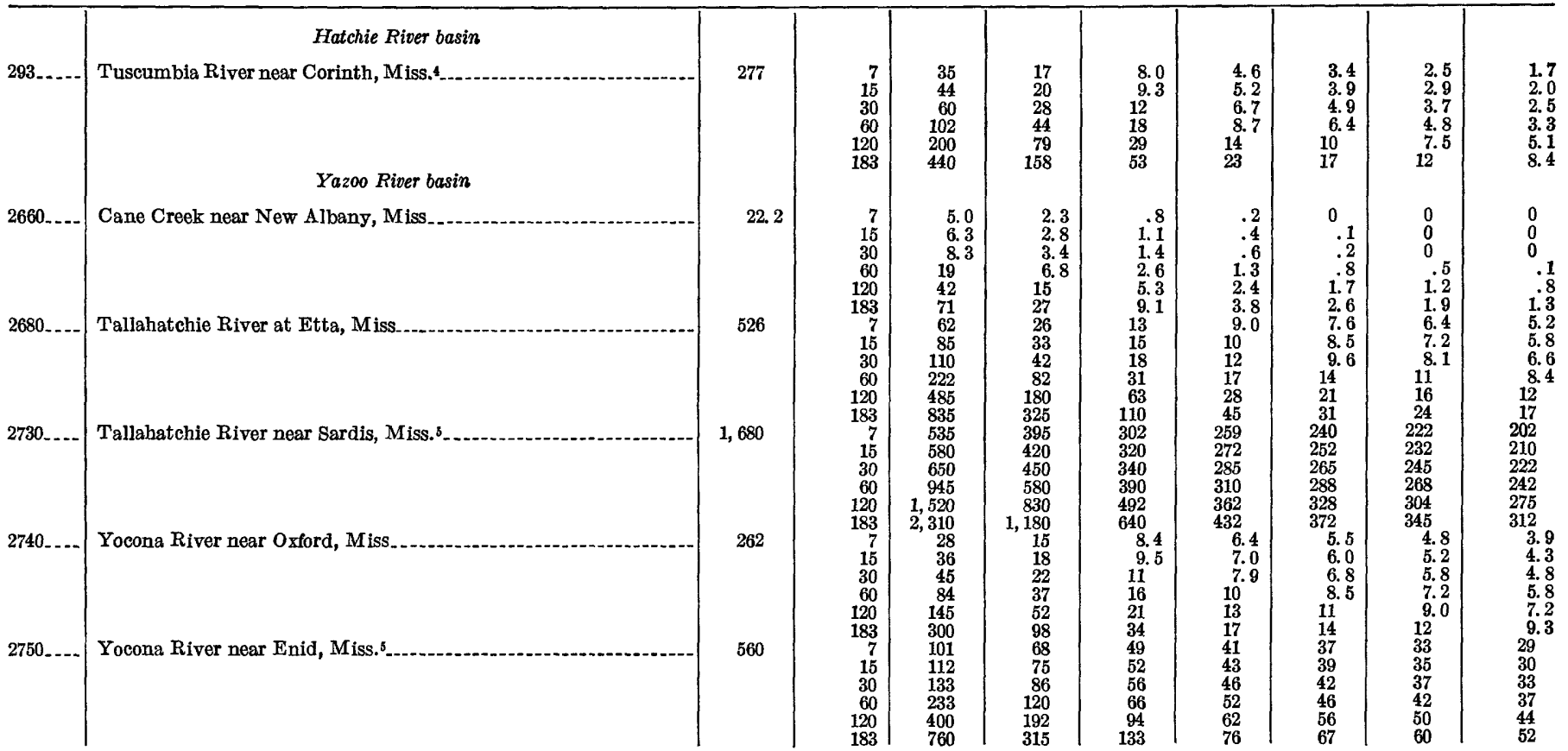

See footnotes at end of table. 
TABLE 3.-Magnitude and frequency of annual low flow at daily-record gaging stations in the Mississippi embayment in Mississippi and Alabama-Continued

[Data are adjusted to period April 1929-March 1958 on basis of relation to data at other gaging stations]

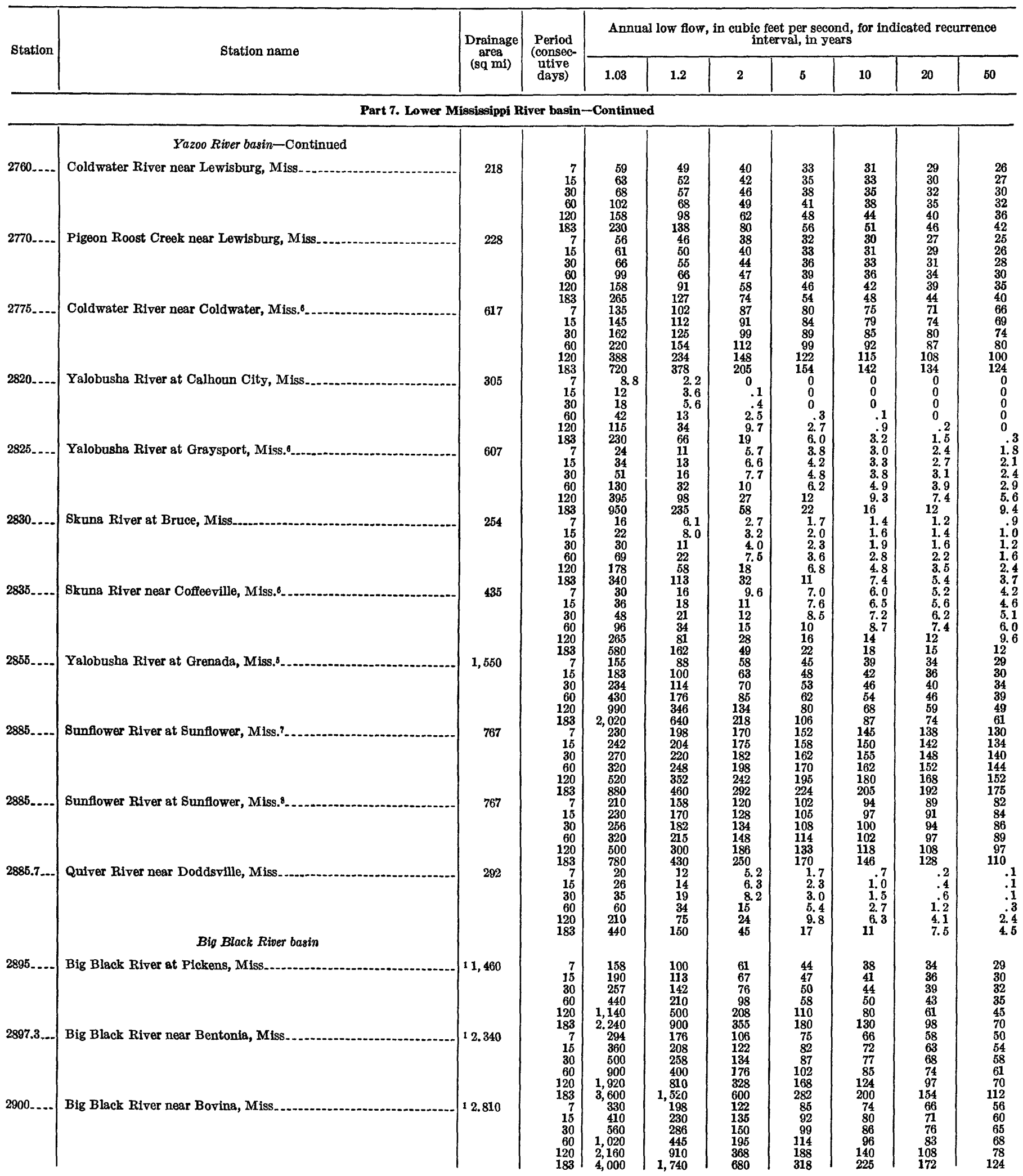

See footnotes at end of table. 
TABLE 3.-Magnitude and frequency of annual low flow at daily-record gaging stations in the Mississippi embayment in Mississippi and Alabama - Continued

[Data are adjusted to period April 1929-March 1958 on basis of relation to data at other gaging stations]

\begin{tabular}{|c|c|c|c|c|c|c|c|c|c|c|}
\hline \multirow{2}{*}{ Station } & \multirow{2}{*}{ Station name } & \multirow{2}{*}{$\begin{array}{l}\text { Drainage } \\
\text { area } \\
\text { (sq mi) }\end{array}$} & \multirow{2}{*}{$\begin{array}{l}\text { Period } \\
\text { (consec- } \\
\text { utive } \\
\text { days) }\end{array}$} & \multicolumn{7}{|c|}{$\begin{array}{l}\text { Annual low flow, in cubic feet per second, for indicated recurrence } \\
\text { interval, in years }\end{array}$} \\
\hline & & & & 1.03 & 1.2 & 2 & 5 & 10 & 20 & 50 \\
\hline
\end{tabular}

Part 7. Lower Mississi ppi River basin-Continued

\begin{tabular}{|c|c|c|c|c|c|c|c|c|c|c|}
\hline $2905 \ldots$ & 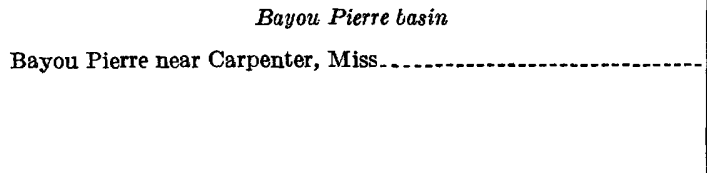 & 371 & $\begin{array}{r}7 \\
15 \\
30 \\
60 \\
120 \\
183\end{array}$ & $\begin{array}{r}59 \\
68 \\
83 \\
150 \\
268 \\
\mathbf{4 1 5}\end{array}$ & $\begin{array}{r}38 \\
42 \\
50 \\
78 \\
146 \\
238\end{array}$ & $\begin{array}{r}26 \\
28 \\
32 \\
\mathbf{4 2} \\
74 \\
120\end{array}$ & $\begin{array}{l}21 \\
22 \\
23 \\
30 \\
45 \\
66\end{array}$ & $\begin{array}{l}19 \\
20 \\
20 \\
26 \\
38 \\
53\end{array}$ & $\begin{array}{l}17 \\
18 \\
18 \\
\mathbf{2 4} \\
\mathbf{3 4} \\
\mathbf{4 4}\end{array}$ & $\begin{array}{l}15 \\
16 \\
16 \\
20 \\
30 \\
35\end{array}$ \\
\hline
\end{tabular}

2 Approximate.

3 Includes $70 \mathrm{sq} \mathrm{mi}$ of noncontributing area upstream from Inland Reservoir on Blackburn Fork.

- Data not to base period; based on observed data 1950-57 and on records for nearby gaging stations.

$\checkmark$ Data for natural conditions prior to operation of reservoir upstream.

- Data for natural conditions; site now inundated by reservoir.

7 Data for natural conditions prior to irrigation withdrawals.

\section{FLOW DURATION}

Flow-duration data for the 78 daily-record gaging stations in the Mississippi embayment are presented in table 4. As in the case of low-flow frequency data, flow-duration data are not shown for the partial-record stations. The data in table 4 can be plotted on logarithmic-probability paper similar to that used in figure 4 if a graphical presentation is desired. The slope of the duration curve so plotted is a quantitative measure of the variability of streamflow. The slopes of flowduration curves for streams having large low-flow yields are flatter than those for streams having small low-flow yields. Thus, the flow-duration data in table 4 are excellent for comparing the flow characteristics.

If it is assumed that no manmade or unusual climatological changes will occur, the adjusted data in table 4 can be used, in water-supply and pollution studies, to predict the long-term distribution of future flows.

Duration data for any particular year can deviate from the adjusted data. For example, during 1954, a year of extreme low flow, the daily discharge of Tombigbee River at Columbus, Miss. (2B4415), equaled or exceeded $170 \mathrm{cfs}$ only 95 percent of the time, whereas during the reference period, the daily discharge equaled or exceeded $170 \mathrm{cfs}$ more than 99.5 percent of the time. Thus, the flow-duration data in table 4 can be used in preliminary planning of water projects, but detailed studies would require further analysis and use of the low-fiow frequency data shown in table 3.

\section{FACTORS AFFECTING LOW FLOW}

The principal factors influencing base flow of streams are (1) the permeability and porosity of the geologic units; (2) the interrelation of the base of each geologic unit, the water table, and the water surface in the 733-833-64-4

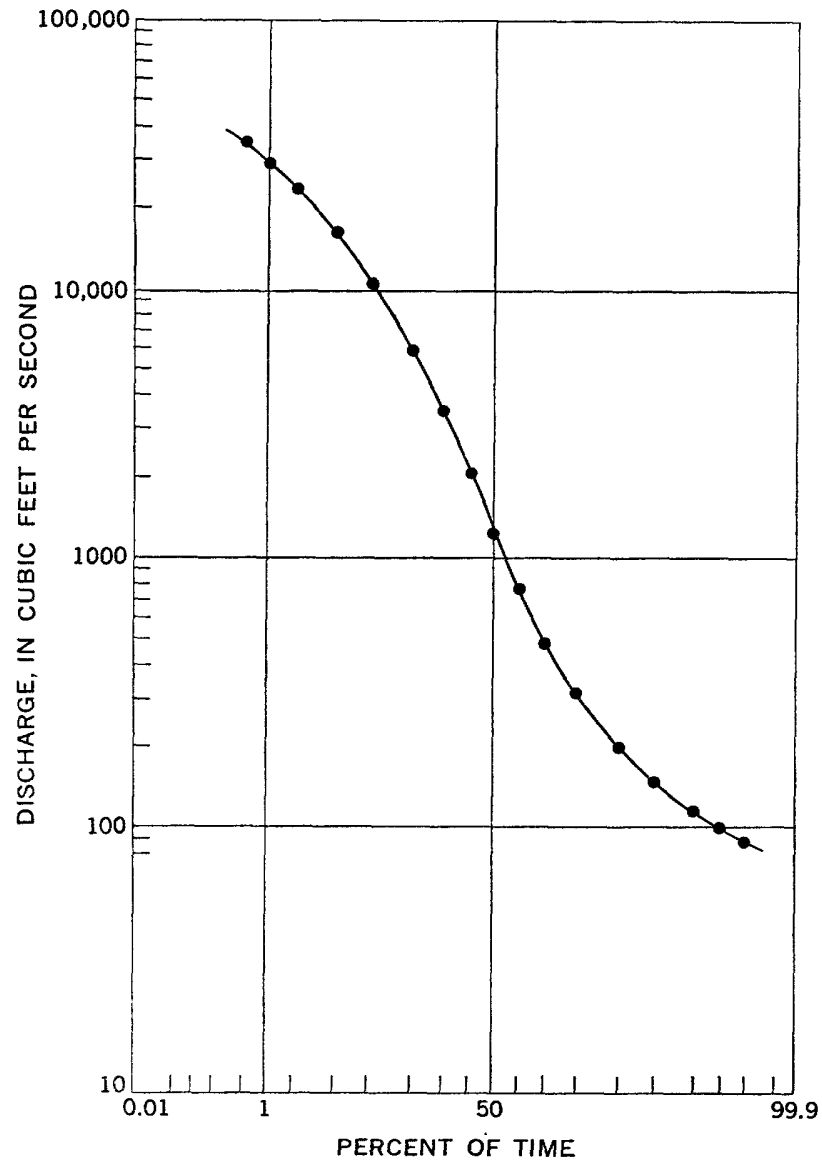

FIGURe 4.-Graph showing flow-duration curve for Pearl River at Jackson, Miss., 1929-57.

stream; and (3) the slope of the water table toward the stream. The geologic units are not homogeneous. For example, the Tuscaloosa Group is not lithologically uniform but consists of irregularly bedded sand, clay, and gravel in varying proportions. These proportions 
TABLE 4.-Duration of daily flow at daily-record gaging stations in the Mississippi embayment in Mississippi and Alabama

[Data are adjusted to period October 1928-September 1957 on basis of relation to data at other gaging stations]

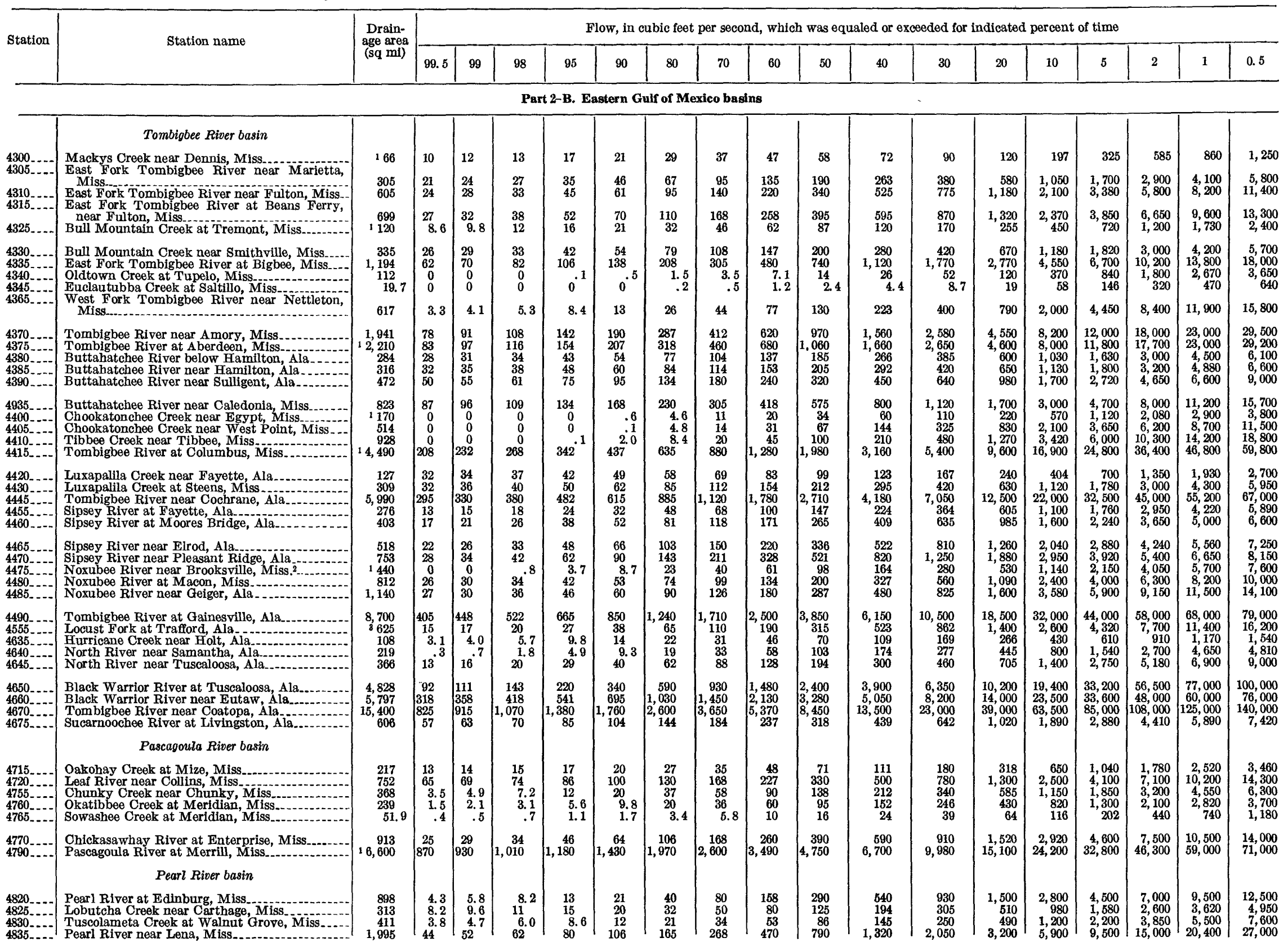




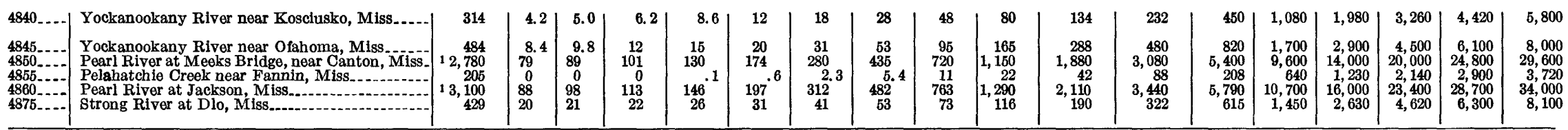

\begin{tabular}{|c|c|c|c|c|c|c|c|c|c|c|c|c|c|c|c|c|c|c|c|}
\hline \multicolumn{20}{|c|}{ Part 3-B. Tennessee River basin } \\
\hline & Tennessee River basin & & & & & & & & & & & & & & & & & & \\
\hline $\begin{array}{l}5925-\cdots \\
5928 \\
-\cdots-.-\end{array}$ & $\begin{array}{l}\text { Bear Creek at Bishop, Ala } \\
\text { Yellow Creek near Doskie, Miss }\end{array}$ & $\begin{array}{l}667 \\
143\end{array}$ & $\stackrel{27}{9.6}$ & $\begin{array}{l}33 \\
11\end{array}$ & $\begin{array}{l}40 \\
12\end{array}$ & $\begin{array}{l}55 \\
15\end{array}$ & $\begin{array}{l}74 \\
19\end{array}$ & $\begin{array}{r}116 \\
27\end{array}$ & $\begin{array}{r}173 \\
38\end{array}$ & $\begin{array}{r}256 \\
54\end{array}$ & $\begin{array}{r}390 \\
\mathbf{7 4}\end{array}$ & $\begin{array}{l}602 \\
102\end{array}$ & $\begin{array}{l}915 \\
145\end{array}$ & $\begin{array}{r}1,450 \\
224\end{array}$ & $\begin{array}{r}2,620 \\
460\end{array}$ & $\begin{array}{r}4,140 \\
850\end{array}$ & $\begin{array}{l}6,680 \\
1,520\end{array}$ & $\begin{array}{l}8,950 \\
2,100\end{array}$ & $\begin{array}{r}11,600 \\
2,820\end{array}$ \\
\hline
\end{tabular}

\begin{tabular}{|c|c|c|c|c|c|c|c|c|c|c|c|c|c|c|c|c|c|c|c|}
\hline & Hatchie River basin & & & & & & & & & & & & & & & & & & \\
\hline $293 \ldots . .$. & $\begin{array}{l}\text { Tuscumbla River near Corinth, Miss.' } \\
\text { Yazoo River basin }\end{array}$ & 277 & 4.7 & 5.7 & 7.1 & 9.8 & 13 & 20 & 30 & 46 & 71 & 116 & 198 & 375 & 920 & 1,840 & 3,400 & 4,700 & 6,300 \\
\hline $\begin{array}{l}2660 \\
2680 \\
2730 \\
2740 \\
2750\end{array}$ & 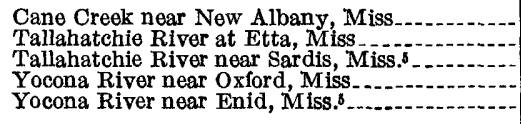 & $\begin{array}{c}22.2 \\
526 \\
1,595 \\
262 \\
560\end{array}$ & $\left|\begin{array}{c}0 \\
7.3 \\
288 \\
6.6 \\
39\end{array}\right|$ & $\begin{array}{c}.1 \\
8.4 \\
302 \\
7.2 \\
42\end{array}$ & $\begin{array}{c}100^{.4} \\
324 \\
4.0\end{array}$ & $\begin{array}{c}14^{.9} \\
360 \\
10 \\
52\end{array}$ & $\begin{array}{c}1.6 \\
19 \\
405 \\
12 \\
61\end{array}$ & $\begin{array}{c}3.0 \\
30 \\
498 \\
17 \\
79\end{array}$ & $\begin{array}{c}5.1 \\
52 \\
610 \\
25 \\
105\end{array}$ & $\begin{array}{c}8.0 \\
90 \\
780 \\
41 \\
152\end{array}$ & $\begin{array}{r}12 \\
162 \\
1,080 \\
66 \\
225\end{array}$ & $\begin{array}{r}19 \\
253 \\
1,520 \\
108 \\
328\end{array}$ & $\begin{array}{r}30 \\
430 \\
2,240 \\
180 \\
500\end{array}$ & $\begin{array}{r}50 \\
810 \\
3,450 \\
340 \\
910\end{array}$ & $\begin{array}{r}106 \\
2,000 \\
5,900 \\
780 \\
2,080\end{array}$ & $\begin{array}{l}192 \\
3,840 \\
9,000 \\
1,420 \\
3,720\end{array}$ & $\begin{array}{r}350 \\
6,800 \\
14,100 \\
2,700 \\
7,000\end{array}$ & $\begin{array}{r}498 \\
9,600 \\
19,200 \\
4,050 \\
10,200\end{array}$ & $\begin{array}{r}690 \\
13,000 \\
25,400 \\
5,900 \\
14,000\end{array}$ \\
\hline $\begin{array}{l}2760 \\
2770 \ldots \\
2775 \\
2820 \\
2825\end{array}$ & 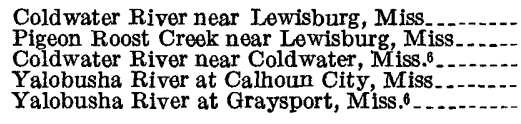 & $\begin{array}{l}218 \\
228 \\
617 \\
305 \\
607\end{array}$ & $\begin{array}{c}32 \\
26 \\
75 \\
0 \\
3.6\end{array}$ & $\begin{array}{l}33 \\
28 \\
78 \\
0 \\
4.4\end{array}$ & $\begin{array}{c}35 \\
30 \\
82 \\
0 \\
5.3\end{array}$ & $\begin{array}{c}39 \\
33 \\
89 \\
0 \\
7.0\end{array}$ & $\begin{array}{l}43 \\
36 \\
96 \\
9.7\end{array}$ & $\begin{array}{c}50 \\
41 \\
110 \\
1.4 \\
17\end{array}$ & \begin{tabular}{c|c}
57 \\
48 \\
126 \\
4.1 \\
28
\end{tabular} & $\begin{array}{c}66 \\
55 \\
148 \\
9.8 \\
52\end{array}$ & $\begin{array}{r}79 \\
64 \\
180 \\
22 \\
100\end{array}$ & $\begin{array}{r}102 \\
78 \\
244 \\
49 \\
200\end{array}$ & $\begin{array}{l}165 \\
105 \\
410 \\
100 \\
410\end{array}$ & $\begin{array}{l}325 \\
172 \\
810 \\
220 \\
950\end{array}$ & $\begin{array}{r}800 \\
450 \\
2,050 \\
640 \\
2,140\end{array}$ & $\begin{array}{l}1,580 \\
990 \\
4,400 \\
1,460 \\
3,500\end{array}$ & $\begin{array}{r}3,200 \\
2,050 \\
10,200 \\
3,000 \\
5,900\end{array}$ & $\begin{array}{r}5,000 \\
3,300 \\
18,000 \\
4,600 \\
8,400\end{array}$ & $\begin{array}{r}7,300 \\
5,000 \\
31,000 \\
6,900 \\
11,500\end{array}$ \\
\hline $\begin{array}{l}2830-.- \\
2835- \\
2855 \\
2885--\end{array}$ & 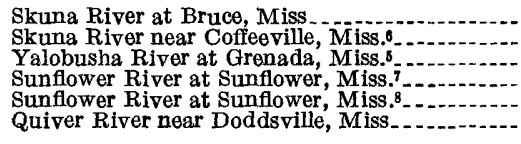 & $\begin{array}{r}254 \\
435 \\
1,550 \\
767 \\
767 \\
292\end{array}$ & $\begin{array}{c}1.3 \\
6.8 \\
41 \\
152 \\
94 \\
.6\end{array}$ & $\begin{array}{c}1.6 \\
7.6 \\
44 \\
160 \\
98 \\
1.2\end{array}$ & $\begin{array}{c}2.0 \\
8.6 \\
50 \\
168 \\
103 \\
2.4\end{array}$ & $\begin{array}{c}2.8 \\
10 \\
60 \\
181 \\
111 \\
3.7\end{array}$ & $\begin{array}{c}3.9 \\
13 \\
74 \\
192 \\
122 \\
6.1\end{array}$ & $\begin{array}{c}6.4 \\
20 \\
103 \\
219 \\
150 \\
13\end{array}$ & $\begin{array}{r}10 \\
30 \\
148 \\
255 \\
188 \\
25\end{array}$ & $\begin{array}{r}17 \\
48 \\
233 \\
308 \\
246 \\
52\end{array}$ & $\begin{array}{r}33 \\
82 \\
410 \\
398 \\
340 \\
116\end{array}$ & $\begin{array}{r}62 \\
142 \\
740 \\
600 \\
520 \\
236\end{array}$ & $\begin{array}{r}124 \\
250 \\
1,370 \\
940 \\
850 \\
420\end{array}$ & $\begin{array}{r}278 \\
500 \\
2,800 \\
1,550 \\
1,510 \\
730\end{array}$ & $\begin{array}{r}860 \\
1,280 \\
5,600 \\
2,620 \\
3,100 \\
1,300\end{array}$ & $\begin{array}{l}1,960 \\
2,650 \\
9,000 \\
3,740 \\
4,300 \\
1,960\end{array}$ & $\begin{array}{r}3,480 \\
4,800 \\
15,000 \\
5,100 \\
5,400 \\
2,650\end{array}$ & $\begin{array}{r}4,650 \\
6,800 \\
21,500 \\
6,000 \\
6,000 \\
2,950\end{array}$ & $\begin{array}{r}6,000 \\
9,200 \\
29,800 \\
6,700 \\
6,600 \\
3,200\end{array}$ \\
\hline 2885.7--- & Big Black River basin & & & & & & & & & & & & & & & & & & \\
\hline \multirow[t]{2}{*}{$\begin{array}{l}2895 \ldots \\
2897.3 \ldots \\
2900 \ldots\end{array}$} & $\begin{array}{l}\text { Big Black River at Pickens, Miss } \\
\text { Big Black River near Bentonia, Miss.......... } \\
\text { Big Black River near Bovina, Miss }\end{array}$ & $\begin{array}{l}11,460 \\
12,340 \\
12,810\end{array}$ & $\begin{array}{l}37 \\
58 \\
70\end{array}$ & $\begin{array}{l}42 \\
64 \\
78\end{array}$ & $\begin{array}{l}48 \\
74 \\
90\end{array}$ & $\begin{array}{r}62 \\
96 \\
116\end{array}$ & $\begin{array}{r}85 \\
130 \\
157\end{array}$ & $\begin{array}{l}136 \\
208 \\
250\end{array}$ & $\begin{array}{l}208 \\
320 \\
388\end{array}$ & $\begin{array}{l}326 \\
500 \\
610\end{array}$ & $\begin{array}{r}540 \\
860 \\
1,030\end{array}$ & $\begin{array}{r}910 \\
1,480 \\
1,790\end{array}$ & $\begin{array}{l}1,600 \\
2,480 \\
3,050\end{array}$ & $\begin{array}{l}2,800 \\
4,350 \\
5,300\end{array}$ & $\begin{array}{l}5,000 \\
7,900 \\
9,600\end{array}$ & $\begin{array}{l}7,600 \\
11,800 \\
14,400\end{array}$ & $\begin{array}{l}\begin{array}{l}11,700 \\
16,800 \\
20,600\end{array} \\
\end{array}$ & $\begin{array}{l}15,200 \\
20,800 \\
25,500\end{array}$ & $\begin{array}{l}19,200 \\
25,800 \\
30,800\end{array}$ \\
\hline & Bayou Pierre basin & & & & & & & & & & & & & & & & & & \\
\hline $2905 \ldots$ & Bayou Pierre near Carpenter, Miss ............. & 371 & 16 & 18 & 19 & 23 & 28 & 40 & 56 & 79 & 120 & 184 & 290 & 500 & 1,050 & 1,910 & 3,700 & 5,300 & 7,100 \\
\hline
\end{tabular}

1 Approximate.

Partly regulated by Bluff Lake; pattern of regulation nearly constant since at least 1948.

Includes $70 \mathrm{sq}$. mi. of noncontributing area upstream from Inland Reservoir on Blackburn Fork.

4 Data not to base period; based on observed data 1950-57 and on records for nearby gaging stations.

- Data for natural conditions prior to operation of reservolr upstream.

7 Data for natural conditions; site now inundated by reservoir.

8 Data for regulated conditions resulting from irrigation withdrawals. 
and the distribution of permeable beds within a geologic unit determine its ability to transmit, store, and yield water. Thus, the interrelation between the low-flow characteristics of a stream and the basin geology has a major influence on the low flow because, during periods when there is no direct runoff, natural streamflow is derived largely from ground water.

A study of the data in table 2 reveals a wide difference in the low-flow yields of the streams in the area. This difference can be attributed largely to the physical properties of the geologic units.

The three major river basins lying wholly within the study area are the Tombigbee, Yazoo, and Big Black; and the six major basins lying partly within the study area are the Pascagoula, Pearl, Tennessee, Hatchie, Wolf, and Bayou Pierre. The low-flow characteristics of the streams in each of these major basins are discussed in the following sections. Low-flow yields are compared by using the 7-day low flow for the 2-year recurrence interval (7-day 2-year) shown in table 2 as an index of low flow. Expressing discharge in table 2 in cubic feet per second per square mile minimizes the effect of size of drainage area and thus emphasizes the effects of basin geology.

\section{EASTERN GULF OF MEXICO BASINS}

TOMBIGBEE-BLACK WARRIOR RIVER BASIN

The Tombigbee River above its confluence with the Black Warrior River drains an area of about 8,900 square miles which includes all or part of each of 24 counties in Mississippi and Alabama. The principal tributaries to the Tombigbee River from within the study area are the East and West Forks, the Buttahatchee, Sipsey, Noxubee, and Sucarnoochee Rivers, and the Tibbee and Luxapalila Creeks.

The low-flow characteristics of streams in the Tombigbee River system vary widely. Generally, tributary streams entering the Tombigbee River and the East Fork Tombigbee River from the east have much higher yields than do those entering from the west. The eastern tributaries lie almost entirely in the Fall Line Hills. Along the northeast side of the Fall Line Hills, in the commingling of plateau and coastal-plain formations and topography, the headwater streams of the tributaries have cut their channels through the unconsolidated sand and gravel of the Tuscaloosa Group and are incised into the nearly impermeable rocks of preCretaceous age. In the interstream areas, widespread deposits of highly permeable sand and gravel of the Upper Cretaceous Series remain. Most of the low flow of the East Fork Tombigbee River near Fulton, Miss. (2B4310), is from the eastern tributaries, principally Mackys Creek. Mackys and Bull Mountain Creeks together contribute about 75 percent of the low flow of
East Fork Tombigbee River. The low flow of the streams on the east side of the rivers is largely from sand units of the Tuscaloosa Group and the McShan and Eutaw Formations.

Mackys Creek (2B4300), the most northern of the east-side tributaries, has a low-flow index of $0.26 \mathrm{cfs}$ per sq mi (cubic feet per second per square mile), which is one of the larger indices of the major tributaries from the east. The main channel of Mackys Creek is deeply cut, and the hill masses surrounding the valley are composed of the Gordo Formation of the Tuscaloosa Group, and the McShan and Eutaw Formations, which accounts, in part, for the comparatively high yield of the creek.

The other major eastern tributaries, Bull Mountain Creek (2B4330), Buttahatchee River (2B4396), and Luxapalila Creek (2B4435), drain areas of similar geology and have low-flow indices of about $0.13 \mathrm{cfs}$ per sq mi. All three streams have their upper reaches in the Pottsville Formation, their middle reaches in the Tuscaloosa Group, and their lower reaches in the McShan and Eutaw Formations. Beaver (2B4388) and Williams (2B4378.5) Creeks, tributaries of the upper Buttahatchee, are in the Coker and Gordo Formations and have low-flow indices of 0.19 and 0.23 cfs per sq mi, respectively. Purgatory (2B4388.5) and Bogue (2B4390.5) Creeks are fed by springs discharging from the Coker and Gordo Formations and have lowflow indices of 0.85 and $0.52 \mathrm{cfs}$ per sq mi, respectively. The stream valleys in the middle and lower reaches are broad and flat, and they are filled with alluvial sediments composed mostly of sand and gravel. There are wide differences in the yields of various reaches of some of these streams owing to differences in the composition of the alluvium.

The yield of Bull Mountain Creek is apparently fairly uniform along the main stem, as indicated by the low-flow index of $0.13 \mathrm{cfs}$ per sq $\mathrm{mi}$ at both the Tremont (2B4325) and Smithville (2B4330) gaging stations. These data indicate that the low-flow yield of Chubby Creek, a major tributary between the gaging stations, is about the same as that of the main stream. The yield of Buttahatchee River seems to be fairly uniform along the main stem, as indicated by the indices of $0.16 \mathrm{cfs}$ per $\mathrm{sq} \mathrm{mi}$ at the Sulligent (2B4390), Caledonia (2B4395), and Kolola Springs (2B4396) stations.

The low-flow yield of the Luxapalila Creek basin is not uniform, as indicated by the 7-day 2-year flows at the following stations: Winfield, Ala. (2B4419), 0.19 cfs per sq mi; Fayette, Ala. (2B4420), 0.33 cfs per sq mi; Millport, Ala. (2B4425), $0.24 \mathrm{cfs}$ per sq mi; Steens, Miss. (2B4430), 0.16 cfs per sq mi; and Columbus, Miss. (2B4435), $0.11 \mathrm{cfs}$ per sq mi. The high indices at Fayette and Millport in the reach canalized in 1922 may 
be due, in part, to the deepening of the channel and to the reduction in evapotranspiration opportunity through canalization, clearing, and drainage of bordering swamps. Records of streamflow before canalization are not available to verify this supposition. In 1942 the lower end of the canal was reexcavated, and it has again filled (1960) with alluvial deposits. The first bottom adjacent to this filled section between the Millport and Steens gaging stations is often covered by a pool of water, which creates a swamp environment. Table 5 shows that appreciable loss in flow occurred during most of the low-water seasons for the concurrent period of record, August 1954-September 1959. These losses are due, in part, to the high evapotranspiration losses from the swamps. It is also possible that water infiltrates into the McShan and Eutaw Formations during periods of low flow, which generally coincide with periods of low water levels in the aquifers.

TABLE 5.-Water losses in Luxapalila Creek between Millport, Ala., and Steens, Miss.

\begin{tabular}{|c|c|c|c|c|}
\hline \multirow[b]{2}{*}{ Month } & \multicolumn{2}{|c|}{$\begin{array}{l}\text { Total cfs-days for } \\
\text { indicated month }\end{array}$} & \multicolumn{2}{|c|}{ Loss } \\
\hline & $\begin{array}{c}\text { At Mill- } \\
\text { port, Ala. } \\
\text { (drainage } \\
\text { area, 241 } \\
\text { sq mi) }\end{array}$ & $\begin{array}{c}\text { At Steens, } \\
\text { Miss. } \\
\text { (drainage } \\
\text { area, 309 } \\
\text { sq mi) }\end{array}$ & Cfs-days & $\begin{array}{l}\text { Percent of } \\
\text { flow at } \\
\text { Millport }\end{array}$ \\
\hline 1954 & \multirow{4}{*}{$\begin{array}{l}1,324 \\
1,329 \\
1,530 \\
2,712 \\
5,628\end{array}$} & \multirow{4}{*}{$\begin{array}{r}977 \\
961 \\
1,322 \\
2,425 \\
5,556\end{array}$} & \multirow{4}{*}{$\begin{array}{r}347 \\
368 \\
208 \\
287 \\
72\end{array}$} & \multirow{4}{*}{$\begin{array}{r}26.2 \\
27.7 \\
13.6 \\
10.6 \\
1.3\end{array}$} \\
\hline September- & & & & \\
\hline Oetober-..... & & & & \\
\hline $\begin{array}{l}\text { November } \\
\text { December-a }\end{array}$ & & & & \\
\hline 1956 & \multirow{3}{*}{$\begin{array}{l}2,620 \\
1,445 \\
1,625 \\
3,177\end{array}$} & \multirow{3}{*}{$\begin{array}{l}2,368 \\
1,251 \\
1,301 \\
3,499\end{array}$} & \multirow{3}{*}{$\begin{array}{l}252 \\
194 \\
324\end{array}$} & \multirow{3}{*}{$\begin{array}{r}9.6 \\
13.4 \\
19.9\end{array}$} \\
\hline $\begin{array}{l}\text { August } \\
\text { September- }\end{array}$ & & & & \\
\hline 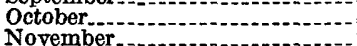 & & & & \\
\hline 1956 & \multirow{4}{*}{$\begin{array}{l}1,827 \\
1,358 \\
3,442 \\
3,137\end{array}$} & \multirow{4}{*}{$\begin{array}{l}1,571 \\
1,034 \\
3,435 \\
3,301\end{array}$} & \multirow{4}{*}{$\begin{array}{r}256 \\
324 \\
7\end{array}$} & \multirow{3}{*}{$\begin{array}{r}14.0 \\
23.9\end{array}$} \\
\hline August _..... & & & & \\
\hline September... & & & & \\
\hline $\begin{array}{l}\text { October-..-- } \\
\text { November... }\end{array}$ & & & & \\
\hline 1957 & \multirow{3}{*}{$\begin{array}{l}1,937 \\
3,375 \\
5,994\end{array}$} & \multirow{3}{*}{$\begin{array}{l}1,777 \\
2,908 \\
5,767\end{array}$} & \multirow{3}{*}{$\begin{array}{l}160 \\
467 \\
177\end{array}$} & \multirow{3}{*}{$\begin{array}{r}8.3 \\
13.8 \\
3.0\end{array}$} \\
\hline August & & & & \\
\hline October......... & & & & \\
\hline 1958 & \multirow{3}{*}{$\begin{array}{l}4,010 \\
6,114 \\
5,080\end{array}$} & \multirow{3}{*}{$\begin{array}{l}4,652 \\
7,210 \\
7,734\end{array}$} & & \\
\hline August & & & $\cdots$ & - \\
\hline October..... & & & & $\begin{array}{l}-1 \\
-1\end{array}$ \\
\hline 1959 & \multirow{2}{*}{$\begin{array}{l}2,570 \\
2,846\end{array}$} & \multirow{2}{*}{$\begin{array}{l}2,650 \\
2,665\end{array}$} & & \\
\hline $\begin{array}{l}\text { August } \\
\text { September }\end{array}$ & & & 181 & 6.4 \\
\hline
\end{tabular}

Yellow Creek, tributary to Luxapalila Creek between Steens and Columbus, Miss., has a low-flow index of $0.09 \mathrm{cfs}$ per sq mi at Steens (2B4433) and drains about half the Luxapalila Creek basin upstream from Columbus. The low flow of Yellow Creek is partly the cause for the low index of $0.11 \mathrm{cfs}$ per sq $\mathrm{mi}$ for Luxapalila Creek near Columbus (2B4435).

The other eastern tributaries to the Tombigbee River between Coal Fire Creek and the Black Warrior River drain the Tuscaloosa Group and the McShan and Eutaw
Formations; they show low-flow indices ranging from 0.03 to $0.12 \mathrm{cfs}$ per sq mi.

The major tributaries to the East Fork Tombigbee River from the west are Big Brown, Donivan, Twentymile, Mantachie, and Boguefala Creeks. These streams are also in the Fall Line Hills; but the upper reaches are in the Coffee Sand, and the lower reaches are in the Eutaw Formation. All are low-yielding streams.

The West Fork Tombigbee River is a low-yielding stream and contributes little water to the Tombigbee River during periods of low flow. The major tributaries of the West Fork are Oldtown, Coonewar, Chiwapa, and Tallabinnela Creeks, which lie mostly within the outcrop area of the Demopolis and Mooreville Chalks. Coonewar and Tallabinnela Creeks are intermittent streams. The upper tributaries of Chiwapa Creek lie in the Pontotoc Ridge. Streams in the northern part of the ridge show higher low-flow indices than do those in the southern part. Oldtown Creek and the lower end of Chiwapa Creek have very small sustained flows, but they are the source of most of the flow in the West Fork during periods of low flow.

Mattubby Creek, tributary to the Tombigbee River upstream from Aberdeen, Miss., is in the outcrop area of the Demopolis and Mooreville Chalks of the Selma Group except in its lower reach, which is in the Eutaw Formation. The part of the stream in the Selma Group is intermittent; the yield of the lower reach is not known.

Tibbee Creek basin lies in the Selma Group except in its headwater area, which is in the Porters Creek Clay and the Clayton Formation. Tibbee Creek is intermittent, but the headwater streams of a major tributary, Chookatonchee Creek-in the Ripley Formation of the Selma Group and in the Clayton Formation-are perennial. This perennial flow is from a small area in the Ripley Formation and is lost to evapotranspiration as it moves downstream across the impermeable chalk of the Selma Group.

The Amory (2B4370), Aberdeen (2B4375), and Columbus (2B4415), Miss., stations on the main stem Tombigbee River have equal low-flow indices of $0.07 \mathrm{cfs}$ per sq mi. The contributing flow of the tributaries from the east and the total increase in drainage area in each reach is such that the low-flow indices are the same at the three stations; however, within a particular reach there can be a marked variation. For example, the main stem Tombigbee River between Aberdeen and Columbus has two major tributaries, Buttahatchee River (2B4400) from the east and Tibbee Creek (2B4410) from the west. Data in table 2 show that the Buttahatchee River contributes most of the base flow to this reach of the Tombigbee River. The lowflow index of the main stem Tombigbee River immedi- 
ately downstream from the Buttahatchee River is about $0.09 \mathrm{cfs}$ per sq $\mathrm{mi}$, and immediately downstream from Tibbee Creek it is about $0.07 \mathrm{cfs}$ per sq $\mathrm{mi}$. As mentioned previously, interpolation of low-flow contribution at an ungaged site should not be based on the size of the drainage area alone; consideration must also be given to surficial geology, physiography, and other factors.

Noxubee River joins the Tombigbee River near Gainesville, Ala. The headwater streams of the Noxubee River are in outcrop areas of the Wilcox Formation and the Porters Creek Clay. They generally are low-yielding streams: low-flow indices are not more than 0.05 cfs per sq mi. The low flows of the Noxubee River in the vicinity of Brooksville, Miss., are partly regulated by Bluff Lake. However, the stream in this reach is naturally intermittent, and the regulation affects only the duration of the periods of no flow. Hashuqua Creek (2B4478), tributary to the Noxubee River upstream from the Macon gage, has a fairly high low-flow index of $0.40 \mathrm{cfs}$ per sq mi. Most of the base flow of the Noxubee River at Macon is from Hashuqua Creek. Running Water Creek (2B4482), tributary to the Noxubee River downstream from Macon, has a low-flow index of $0.10 \mathrm{cfs}$ per sq mi. Most of the base flow of Hashuqua Creek is from the headwater area which is in the Wilcox Formation; Running Water Creek basin is almost entirely in the Porters Creek Clay and, consequently, does not have a high yield.

The Sucarnoochee River drainage basin in Mississippi is in the Wilcox and Naheola Formations and the Porters Creek Clay. Low flows of streams in the center of this area are about twice those of streams in other parts of the basin owing to the yield from the Naheola Formation. To the north of this area, the Naheola Formation consists mostly of nonyielding strata.

At its southern extremity in Alabama, the embayment extends into the outcrop area of sands and clays of Tertiary age: the Clayton, Porters Creek, Naheola, and Nanafalia Formations; the Tuscahoma Sand; the Hatchetigbee, Tallahatta, and Lisbon Formations; and the Gosport Sand. Most streams in this area drain more than one of these formations. The low flow of Kinterbish Creek near York (2B4690) is predominantly from the Naheola and Nanafalia Formations and the Tuscahoma Sand, and the low-flow index of $0.08 \mathrm{cfs}$ per sq mi might be considered representative of flow from these three formations combined. The yields of streams in the Wilcox Group (Wilcox Formation in Mississippi) are higher in this area than are those to the north in the Pearl and Yazoo River basins.

South of the outcrop area of the Eutaw Formation in Alabama, a belt of Mooreville and Demopolis Chalks of the Selma Group that is about 20 miles wide extends northwestward from the eastern margin of Marengo and Hale Counties into Mississippi. Streams draining these units are similar to those in Mississippi in that they react quickly to heavy rainfall but have little ability to sustain flow during dry periods. None of the streams listed in table 2 are representative of this particular area in Alabama.

Of the streams tributary to the Black Warrior River, Davis Creek below Abernant (2B4628), 0.04 cfs per sq mi, New River near Winfield (2B4452.45), $0.04 \mathrm{cfs}$ per sq mi, and North River near Samantha, Ala. (2B4640), 0.02 cfs per sq mi, may be regarded as typical streams incised into the Pottsville Formation. However, the major area of outcrop of this formation is outside the embayment.

Yellow Creek near Tuscaloosa, Ala. (2B4630), 0.28 cfs per sq mi, is bedded in the nearly impermeable rocks of the Pottsville Formation. In the interstream areas there are extensive outcrops of the Coker Formation, and along the stream there are terrace deposits of the Black Warrior River. Both of these formations are highly permeable and contribute to the low flow of Yellow Creek.

The low-flow indices for Big Sandy Creek (2B4654.9), $0.27 \mathrm{cfs}$ per sq mi, and Elliotts Creek (2B4654.95), 0.32 cfs per sq mi, near Mound ville, Ala., are not representative of the formations from which the base flow of the streams is derived. The high yield of Big Sandy Creek is largely from Big Sandy Spring, which discharges directly into the channel from pre-Cretaceous rocks about 4 miles south of Coaling. The average flow of the spring is about $16 \mathrm{cfs}$. Elliotts Creek near Moundville flows through the outcrop of the Gordo Formation and is bordered by widespread terrace deposits of the Black Warrior River. It is fed by numerous seeps and small springs that emerge at the contact between these geologic units.

The upper part of the Leaf and Chickasawhay River basins are the only part of the Pascagoula basin in the Mississippi embayment. The head of the Leaf River and its major headwater tributary, Oakahay Creek, are in the outcrop area of the Jackson Group, the Forest Hill Sand, and the Vicksburg Group, all of which are low-yielding units. The low-flow index of streams in this area is less than $0.02 \mathrm{cfs}$ per sq mi. Farther south the streams drain areas of the Catahoula Sandstone and the Citronelle Formation. Most of the base flow of the Leaf River near Collins, Miss. (2B4720), where the low-flow index of the river is $0.11 \mathrm{cfs}$ per sq $\mathrm{mi}$, is from the Citronelle Formation.

The upper Chickasawhay basin also includes a number of geologic formations. Okatibbee Creek 
(2B4760), which is almost entirely in the Wilcox Formation, and Chunky Creek (2B4755), which is in the Tallahatta Formation, the Sparta Sand, and the Cook Mountain and Cockfield Formations, have about the same low-flow index. The Chickasawhay River is formed at Enterprise (2B4770) by the confluence of Chunky and Okatibbee Creeks. Approximately half of the low flow of Chickasawhay River at this location is from the lower fourth of the Chunky and Okatibbee basins, which are in the outcrop areas of the Tallahatta and Wilcox Formations. The Tallahatta Formation in this area includes the Meridian Sand Member, which appears to be a high-yielding unit.

\section{PEARL RIVER BASIN}

Approximately half the Pearl River basin in Mississippi is in the Mississippi embayment. The headwater streams of the Pearl River are in the Wilcox Formation, and most are intermittent streams. The main stem of the Pearl River in this area has a wide swampy flood plain. Most of the base flow of the Pearl River at Edinburg, Miss. (2B4820), is from the Tallahatta Formation in the area just upstream from Edinburg.

Some of the major tributaries to the Pearl River north of Jackson are Lobutcha, Tuscolameta, and Pelahatchie Creeks, and the Yockanookany River. Lobutcha Creek and the Yockanookany River, which are tributaries from the north, drain areas of similar geology. The upper reaches of both tributaries are in the Wilcox Formation and are intermittent. The middle reaches are in the Tallahatta Formation, the Winona Sand, and the Zilpha Clay. The lower reach of Labutcha Creek is in the Sparta Sand, and the lower reach of Yockanookany River is in the Sparta Sand and the Cook Mountain and Cockfield Formations. Lobutcha Creek (2B4825) has a low-flow index of 0.04 cfs per sq mi, as compared to the low-flow index of 0.03 efs per sq mi for the Yockanookany River (2B4845). The low-flow yields of streams in both basins are quite variable owing to scattered small springs. Tuscolemeta Creek drains areas of the Sparta Sand and the Cockfield Formation, and the main stem is in the Cook Mountain Formation. The low-flow index of this creek (2B4830) is 0.02 cfs per sq mi. Pelahatchie Creek (2B4855) is in the Jackson Group and is an intermittent stream. Some of the small headwater streams are perennial, but the base flow is not sustained for more than a few miles from the source owing to evapotranspiration losses.

The main channel of the Pearl River between Edinburg and Lena is mostly in the Sparta Sand. The median 7-day low flow at Lena (2B4835) is about 4 times that at Edinburg (2B4820). About two-thirds of this increase is due to inflow into the main channel and small tributaries, and about one-third is from Lobutcha and Tuscolameta Creeks.

The upper part of the main channel of the Pearl River between Lena and Meeks Bridge is in the Cockfield Formation and the lower part is in the Jackson Group. The low-flow index at Meeks Bridge (2B4850) is about 25 percent greater than that at the Lena station; about two-thirds of the increase is from the upper part of the main channel, and about one-third is from Yockanookany River. The low-flow yield from the area in the Jackson Group is small. The part of the Pearl River between Meeks Bridge and Jackson is entirely within the Jackson Group, and the median 7-day low flow is about the same at both points.

Strong River (2B4875), which joins the Pearl River south of Jackson, has the highest yield of any tributary to Pearl River in the study area.

The headwater streams of the Strong River, which have low yields, drain areas in the Jackson Group, the Forest Hill Sand, and the Vicksburg Group. Most of the low flow of the Strong River is from the smaller tributaries in the middle and lower reaches, which drain areas in the Citronelle Formation. The lower main stem of the Strong River is in the Catahoula Sandstone, from which only a small part of the base flow is derived.

\section{TENNESSEE RIVER BASIN}

A very small area in northeastern Mississippi and northwestern Alabama drains to the Tennessee River. Yellow Creek and Bear Creek are the principal tributaries in the area. Yellow Creek is primarily in the Eutaw Formation and has a low-flow index of $0.11 \mathrm{cfs}$ per sq mi at Doskie, Miss. (3B5928). Bear Creek heads in Alabama, loops through Mississippi for a short distance, and then flows back into Alabama. The main stem in most locations is in Paleozoic rocks of Mississippian age; the surrounding uplands and small tributaries, however, are in the Tuscaloosa Group, from which most of the base flow of Bear Creek is derived. The low-flow index of Bear Creek near Tishomingo, Miss. (3B5921), which is upstream from Little Bear Creek, is $0.11 \mathrm{cfs}$ per sq $\mathrm{mi}$. There is a wide divergence in the base-flow yield of the smaller tributaries of Bear Creek.

\section{LOWER MISSISSIPPI RIVER BASIN}

HATCHIE RIVER BASIN

The heads of the Hatchie and Tuscumbia Rivers and of Muddy Creek are in Mississippi. Muddy Creek (7-0294.15) is in the outcrop area of the Porters Creek Clay and the Clayton Formation, and it has a low-flow index of 0.009 cfs per sq mi. Tuscumbia River (7-0293) is in the Selma Group and has a low-flow index of 0.03 cfs per sq mi. This flow is principally from the McNairy 
Sand Member of the Ripley Formation; the base flow of tributaries in the Coffee Sand is very low. The headwater area of the main stem of the Hatchie River (7-0292.5) is also in the MeNairy Sand Member and has a low-flow index of about $0.06 \mathrm{cfs}$ per sq mi. The flows of the individual tributaries vary considerably, however, and the low-flow yield of the West Branch is about twice that of the main stem.

\section{WOLF RIVER BASIN}

Wolf River, which heads in Benton County, Miss., is predominately in the Tallahatta Formation. The upper reach of the main stem is in the Wilcox Formation and has a low-flow index of about $0.08 \mathrm{cfs}$ per sq mi. Grays Creek (7-0303.9), which is entirely in the Tallahatta Formation, has a low-flow index of 0.17 cfs per sq $\mathrm{mi}$. At the Rossville, Tenn., gaging station, Wolf River has a low-flow index of $0.30 \mathrm{cfs}$ per sq mi.

\section{YAZOO RIVER BASIN}

The Yazoo River basin is composed of two nearly equal areas having different physical characteristics. One area, the North Central Plateau (fig. 2), is gently rolling hilly land terminated on the west side by the Loess Hills at the edge of the Yazoo Delta (shown as Yazoo Basin on fig. 2). The other area is the Yazoo Delta, a flat alluvial plain now protected from Mississippi River overflow by levees. Streams draining from the hills of the North Central Plateau through the Loess Hills into the Yazoo Delta have flow characteristics different from streams that drain only from either the North Central Plateau or the Yazoo Delta.

Coldwater, Tallahatchie, Yocona, and Yalobusha Rivers are the four major tributaries draining the hilly section. Each of these streams has a flood-control reservoir upstream from the western edge of the Loess Hills.

The main stem of the Coldwater River upstream from Arkabutla Dam is in the Tallahatta Formation and has a low-flow index of about 0.2 cfs per sq mi; the middle reach is in the Sparta Sand and has a lowflow index of about $0.2 \mathrm{efs}$ per sq mi. The lower reach is in an area blanketed by loess and terrace deposits, a part of which is now inundated by Arkabutla Reservoir. Streamflow in the main stem Coldwater River downstream from Arkabutla Reservoir is regulated by the operation of the reservoir. Most of the basin below the reservoir is in the Mississippi River alluvium.

The headwater streams of Pigeon Roost Creek, the major tributary to the Coldwater River, are in a part of the Tallahatta Formation that yields little water, and they have a low-flow index of $0.01 \mathrm{cfs}$ per sq mi at Holly Springs (7-2764.4). The middle reach is in the
Sparta Sand, from which considerable flow is derived. The low-flow index for the middle and upper reaches of the main stem is 0.16 cfs per sq mi $(7-2765)$. The lower reach of Pigeon Roost Creek is in an area blanketed by loess and terrace deposits which contribute little to the base flow of the stream.

The headwater streams of the Tallahatchie River are principally in the Ripley and Clayton Formations and in the Porters Creek Clay. Those streams in the Clayton and Porters Creek are generally intermittent. Streams in the McNairy Sand Member of the Ripley Formation have fairly high low-flow indices. As an example, the Upper Tallahatchie River is partly in the MeNairy Sand Member and has a low-flow index of 0.38 efs per sq mi (7-2655). During periods of low flow, the total flows of such headwater tributaries exceed the flow observed downstream in the Tallahatchie River at Etta (7-2680). As the base flows move downstream across strata that do not yield water, the flows are reduced by evapotranspiration losses.

Tippah River is a major tributary of the Tallahatchie River downstream from Etta and is the source of most of the low flow in the Tallahatchie at this point. Tippah River headwater streams are in the Porters Creek Clay and the Wilcox Formation, and they have small low-flow indices. Most of the low flow of the Tippah River is from streams such as Chewalla Creek (7-2699.7), low-flow index of $1.3 \mathrm{cfs}$ per sq mi, which are in the Tallahatta Formation. Streams in this formation and in this area have the highest yields of any of the streams in the study area.

Most of the Tallahatchie River from the Tippah River to Sardis Dam is in the Tallahatta Formation, and much of the reach is now inundated by the reservoir. Before inundation, the low-flow yield of the Tallahatchie River more than doubled in this reach. Most of the tributaries to the Tallahatchie are also in the Tallahatta Formation and have low-flow indices of about $1 \mathrm{cfs}$ per sq mi. The flow of Tallachatchie River is regulated downstream from Sardis Reservoir.

Yocona River headwater streams are in the Porters Creek Clay and the Wilcox Formation and have lowflow indices that average about 0.03 efs per sq mi. The middle reach, the lower part of which is now inundated by Enid Reservoir, is in the Tallahatta Formation. The yields of streams in the Tallahatta Formation, about $0.1 \mathrm{cfs}$ per sq $\mathrm{mi}$, are much lower than those of streams in this formation in the Tallahatchie River basin. Streamflow in the lower reach of the Yocona River is regulated by the operation of Enid Reservoir.

The Yalobusha River system upstream from Grenada Dam is composed of two major streams, the Yalobusha 
and Skuna Rivers, which drain geologically similar areas. The headwater streams are in the Porters Creek Clay and are intermittent. More than half the drainage area above Grenada Reservoir is in the Wilcox Formation. Streams in the part of the Skuna basin that is in the Wilcox Formation have about twice the low-flow yield of streams in the geologically similar area in the Yalobusha basin. The low-flow indices of the Skuna (7-2835) and Yalobusha (7-2825) Rivers upstream from the reservoir are 0.02 and $0.009 \mathrm{cfs}$ per sq mi, respectively. The main stem of Yalobusha River immediately below the dam is in the Tallahatta Formation, in an area blanketed by loess and terrace deposits; most of the lower basin, however, is in the Mississippi River alluvium.

A number of small streams in the Yazoo River basin head in the Bluff or Loess Hills and flow into the Yazoo Delta. The loess belt is fairly narrow in Grenada, Carroll, and Holmes Counties and becomes wider toward the north in De Soto and Tate Counties and toward the south in Yazoo and Warren Counties. The loess is underlain by terrace sand and gravel that is as much as 40 feet thick.

The northernmost Bluff Hills streams are almost entirely in the loess belt and have low-flow indices as low as $0.02 \mathrm{cfs}$ per sq mi. The low-flow indices of the Bluff Hills streams increase progressively from the north toward the central part of the area, where the streams head in the Sparta Sand and have low-flow indices of as much as $0.15 \mathrm{cfs}$ per sq mi. The southernmost Bluff Hills streams have cut through the terrace deposits into the Yazoo Clay except in their lower reaches, which are in the Mississippi River alluvium. Most of the streams are intermittent.

Little or no base flow seems to be derived from the sand and gravel covered by the loess. The highly impermeable loess probably prevents appreciable recharge to the terrace deposits, which, under normal conditions, are prolific aquifers.

The main stems of the Coldwater, Tallachatchie, and Yazoo Rivers closely parallel the base of the bluff line (the eastern boundary of the Yazoo Delta) and drain a part of the Yazoo Delta as well as the entire hill section of the Yazoo River system. As mentioned previously, the flow characteristics of the lower Yazoo River system have been altered by the operation of four floodcontrol reservoirs. Outfiows from the reservoirs are limited during the normal flood season, December to May, and are regulated from June to September to empty the flood-control storage during the first part of the low-water season. Thus, normal operation of the reservoirs increases the flow of streams below them during June to September. Analyses of low-flow characteristics of streams downstream from the reservoirs would require a detailed study.

The principal streams entirely within the Yazoo Delta are the Sunflower River, Steele Bayou, and Deer Creek. Complete analysis of streamflow characteristics in the area is impracticable. The limits of the drainage basins are poorly defined because of the extremely flat terrain, and the streamflow of any one basin is subject to interflow from other basins. The clearing, snagging, and enlarging of the channels, the continuing changes and additions to drainage ditches, and the changes in drainage patterns modify the hydrologic characteristics of streams within the area. Landowners are gradually clearing and filling low swamp areas for use as farm land. All these factors affect the lowflow characteristics of streams in the area; irrigation withdrawals, however, have had a much greater effect upon streamflow in the area than any other factor.

Irrigation withdrawals in the area are not totally consumptive. For example, in rice irrigation, some of the water withdrawn is returned to the stream because of (1) leaks in the levees around the fields, (2) drainage of the fields during the growing season, and (3) drainage of the fields after the growing season. Streamflow in some reaches of the Sunflower River is augmented by irrigation water that is pumped from wells.

Irrigation withdrawals in the Yazoo Delta were not appreciable prior to 1951 ; since that time, however, the low flows of streams in the area have been affected by a great increase in diversions. For this reason streamflow data in this area were analyzed for two periods: the period of natural flow prior to appreciable irrigation withdrawals, and the period of regulated flow due to irrigation withdrawals. Low-flow indices for the Sunflower and Hushpuckena Rivers and Bogue Phalia show reductions in low-flow indices of 27-36 percent resulting from withdrawals for irrigation since 1951.

The Sunflower River basin is wholly within the Mississippi River alluvium; however, the natural low-flow yields of segments of the basin differ considerably, as indicated by the variation of the low-flow indices of the tributary streams. Hushpuckena River (7-2881.5), which drains the northwestern part of the basin, has a natural low-flow index of 0.09 cfs per sq mi; Quiver River (7-2885.7), which drains the northeastern part of the basin, has an index of $0.02 \mathrm{cfs}$ per sq mi; and Bogue Phalia (7-2886.5), which drains the west-central part of the basin, has an index of $0.15 \mathrm{cfs}$ per sq mi. This variation in natural low-flow yield is due, in part, to the variation in composition of the alluvial deposits. Generally, the alluvium in the eastern part contains more clay and has a lower storage capacity than does that in the western part. The upper reach of the main stem of the Sunflower River above Clarksdale (7-2880) 
has a natural low-flow index of 0.09 cfs per sq mi, which is considerably lower than that of the other reaches of the main stem. The fact that the channel above Clarksdale is not cut into the alluvium as deeply as the main stem below Clarksdale accounts, in part, for the lower yield of the upper reach. The increments of base flow from other reaches of the main stem vary. The increment in the reach between Clarksdale and Lombardy (7-2882) has a low-flow index of about 0.15 cfs per sq mi; the increments in some of the reaches downstream from Lombardy have low-flow indices that exceed $0.3 \mathrm{cfs}$ per sq $\mathrm{mi}$. The increase in low-flow yield of the Sunflower River in a downstream (southerly) direction is due to the variation in the composition of the alluvial material, to the generally southwestern movement of ground water in the alluvium, and to the increase in channel width, which increases the area in contact with the aquifer.

Information concerning the low flows of Steele Bayou and Deer Creek is limited. Steele Bayou is intermittent in the vicinity of Grace and Rolling Fork, and had minimum flows of about $3 \mathrm{cfs}$ at Onward during the droughts of 1952 and 1954. The low flows of these streams probably were affected by withdrawals for irrigation or by return flows.

Lake Washington is the head of the West Prong of Steele Bayou. A study to determine the effect of irrigation withdrawals on stages in this lake is reported by Harbeck and others (1961). The study indicates that when the ground-water level in the area is high, withdrawals from the lake would be balanced partly by an increase in the amount of seepage into the lake. Under these conditions, an increase in the amount of withdrawals from Lake Washington would not result in lowering the lake level by an equivalent amount.

In the Yazoo Delta area, the banks of Deer Creek form natural levees, and much of the land surface near the creek slopes away from the banks. In places, openings in this natural levee allow small tributaries to drain into the creek. During the severe droughts of the 1950 's, dams were constructed at many places along Deer Creek to store water for irrigation, and no appreciable flow bypassed these structures. Thus, during drought periods there is practically no outflow from the creek. Also, the structures cause periods of no flow to occur before the normal low-flow season. For example, during May 1955, Deer Creek was reported to be dry at Hollandale, and flows of nearby streams were not unusually low.

\section{BIG BLACK RIVER BASIN}

The headwater streams of the Big Black River are in the Wilcox Formation and are intermittent. Tributary streams in the vicinity of Kilmichael are in the
Tallahatta Formation and have low-flow indices of about $0.05 \mathrm{cfs}$ per sq mi. The main stem of the Big Black River between Kilmichael and Vaiden is in the Tallahatta Formation, and most of the base flow.at Vaiden (7-2892.6) is from this reach of the channel. There is little gain in the base flow of the Big Black River between Vaiden and West (7-2893.5). The main stem and most of the tributaries are in the nearly impermeable Zilpha Clay. The low-flow index of the Big Black River doubles between West and Pickens (7-2895), the next station downstream, mostly because of gain from the Sparta Sand and the Cockfield Formation.

Most of the drainage area between Pickens and Bear Creek is in the Cockfield Formation, and the low-flow index of Doaks Creek (7-2895.3), a major tributary in this reach, is $0.07 \mathrm{cfs}$ per sq $\mathrm{mi}$. The reach between Bear Creek and Bentonia (7-2897.3) is in an area blanketed by loess and terrace deposits, and the tributary streams are intermittent.

The Big Black River downstream from Bentonia is in an area blanketed by loess and terrace deposits, and the gain in the 2-year low-flow yield in the reach between Bentonia and Bovina (7-2900) is about 15 percent from a 20-percent increase in drainage area. As most tributary streams in this area are intermittent, the gain is primarily in the main channel. The gain in low flow of the Big Black River downstream from Bovina is not known, but Fourteenmile Creek, a major tributary in the lower reach, is an intermittent stream.

\section{BAYOU PIERRE BASIN}

The uppermost reaches of Bayou Pierre are in the Citronelle Formation and have high base flows. Most of the upper half of the basin, however, is in the Catahoula Sandstone. The low-flow index of Bayou Pierre (7-2905) immediately upstream from Whiteoak Creek is $0.07 \mathrm{cfs}$ per sq mi. The low-flow index of Whiteoak Creek (7-2905.5), which is entirely in the Catahoula Sandstone, is $0.008 \mathrm{cfs}$ per sq mi. Downstream from Whiteoak Creek, Bayou Pierre is in an area blanketed by loess and terrace deposits that contribute little base flow. Thus, the low-flow index for the Bayou Pierre at its mouth is less than $0.05 \mathrm{cfs}$ per sq mi.

\section{LOW FLOWS AND GROUND-WATER FLUCTUATIONS}

In the discussion of factors influencing low flows, three significant factors were enumerated (p. I 21). The first of these factors expresses the influence of the fixed physical properties of the aquifer in contact with or adjacent to the stream, and the other two are variable factors that would need to be considered in relating the water level in the aquifer in contact with the stream to the low flow. Because the geologic units are the 
natural storage reservoirs that sustain base flow, variations in altitudes of the ground-water table or of the water surface in the streams and the resulting variation in the slope of the water table toward the stream, influence the rate at which the aquifer will yield water to the stream. Thus, fluctuations in the base flow of a stream are related to the fluctuations of the ground water in the geologic units from which the stream receives its base flow, and the ground-water yield to a stream is represented approximately by the low flow of a stream.

Where a stream receives its base flow from a single geologic unit, the altitude of the ground water in the geologic unit may be a direct index of the base flow in the stream. Very few streams, however, receive their base flows from a single formation; and the larger the stream, the more complex the interrelation between base flow and ground-water fluctuations becomes.

The size of the surface drainage area is not always a dependable basis for appraising the low-flow characteristics of streams, as it frequently bears little relation to the area of the geologic units from which the base flow of a stream is derived. However, as the size of drainage area is readily available information, it has been used to compute the unit runoff per square mile presented in table 2. These values of unit runoff provide an index for use in further investigation into the physical basis for areal variations in the base flow of streams.

Differences in low-flow yields of streams draining areas of similar geology may be partly attributable to variations in the altitude of the water table with respect to the water surface in streams.

\section{METHOD OF STUDY}

The method used to analyze basic data and to obtain the low-flow frequency and flow-duration data presented in this report is essentially graphical. The procedure consisted of smoothing the low-flow data for long-term records by comparing them with data from other longterm stations and by then adjusting the shorter records to the reference period through their relations with the long-term records. Statistical principles were used as a guide in evaluating the relations.

The following long-term stations served as a basis for the low-flow analysis in Mississippi and Alabama:

\footnotetext{
Station Name

2B4415 ... Tombigbee River at Columbus, Miss.

2B4500..- Mulberry Fork near Garden City, Ala.

2B4555...- Locust Fork at Trafford, Ala.

2B4790.-- PascagoulaRiver at Merrill, Miss.

2B4860..- Pearl River at Jackson, Miss.

2B4875.... - Strong River at Dlo, Miss.

3 B6040 - - Buffalo River near Flat Woods, Tenn.

7-0295 -..- Hatchie River at Bolivar, Tenn.

7-0305... Wolf River at Rossville, Tenn.

7-3645 . . _ Bayou Bartholomew near Beekman, La.
}

Smoothed low-flow frequency curves for these stations were taken from a report by Hardison and Martin (1963). Smoothed flow-duration curves were obtained by drawing smooth curves through the plot of the observed data for the reference period after giving some consideration to the shape of the flow-duration curves at the other long-term stations.

Index stations were selected from the remaining stations having the longer records to obtain a representative distribution over the area. The low-flow records at these index stations were related to those at the longterm stations, and then they were used as a base to which to relate the flow data at stations having records shorter than those at the index stations. Data from stations having less than 5 years of record and data from low-flow partial-record stations were related to data from one of the longer term stations.

\section{BASIC DATA FOR THE ANALYSIS}

The basic data for the results presented in this report are the records of discharge collected at 78 daily-record and 141 partial-record stations in the Mississippi embayment in Mississippi and Alabama. The location of these stations is shown on plate 1 . The names of the stations are given in table 2 .

Most of the streamflow records used in the analysis have been published annually in reports of the Geological Survey. A few of them were furnished by other agencies. Of the 14 parts into which the United States is divided to facilitate publication of the records, parts of 3 are included in the area (fig. 5) covered by this report. The three parts are:

2-B, South Atlantic slope and eastern Gulf of Mexico basins, Ogeechee River to Pearl River. 3-B, Cumberland and Tennessee River basins.

7, Lower Mississippi River basin.

The part in which a station is located is indicated by the first digit of the station number, and the subdivision of the part is indicated by the letter in the second place. In the number for station $2 \mathrm{~B} 4380$, for example, 2B identifies the station as being in Part 2-B.

Records of daily discharge for gaging stations having five or more complete consecutive water years not affected by regulation or diversion were processed by an electronic computer to obtain (1) the lowest mean discharge occurring during each year for selected numbers of consecutive days and (2) the number of daily flows each year between selected limits of discharge. Tables 6 and 7 are examples of tables resulting from this processing. If the natural flow at a station became regulated or was affected by diversions as the result of manmade changes, the data for the record so affected were not used. Records for less than 5 com- 


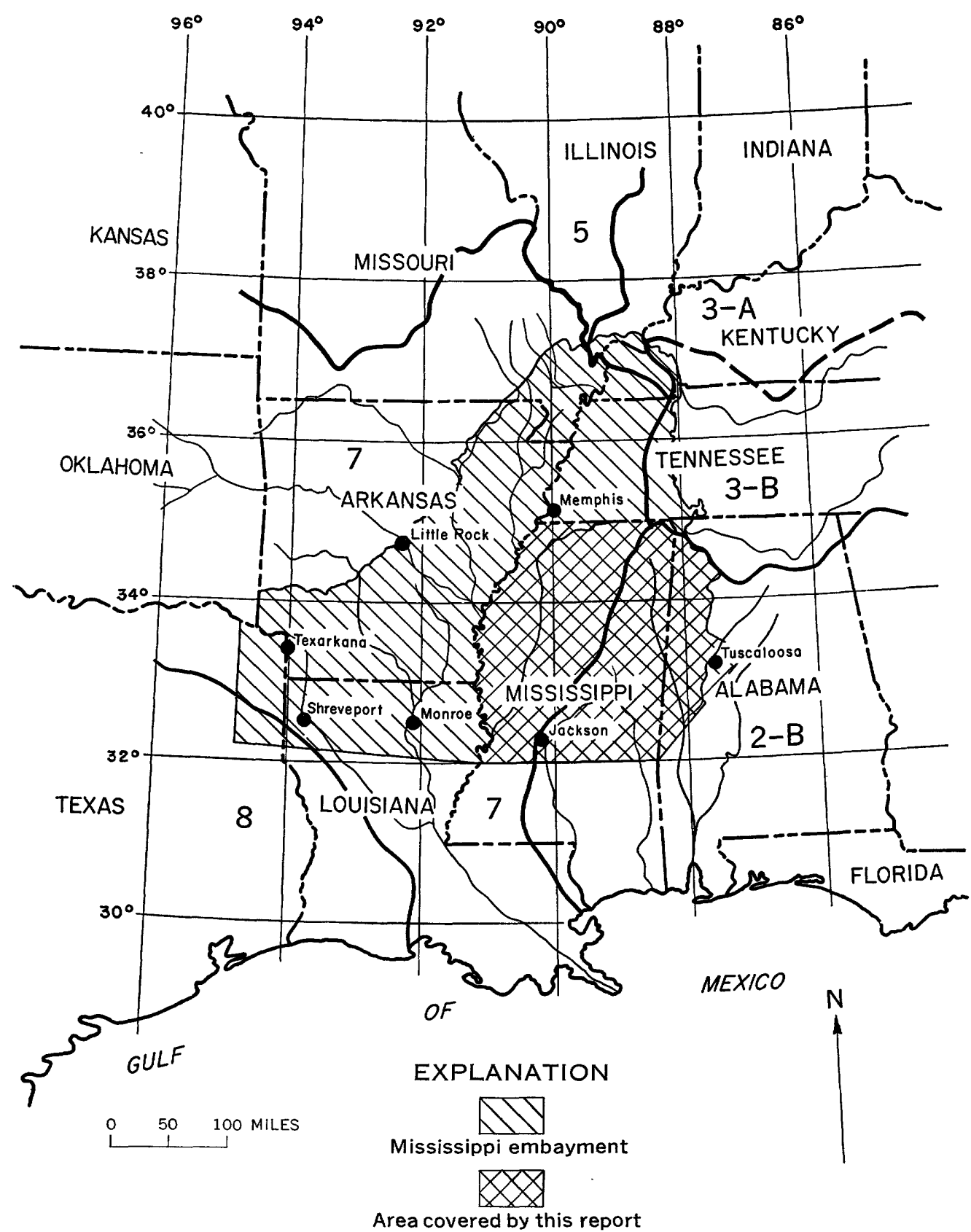

F IGUR 5.-Map of the Mississippi embayment showing areas covered, by numbered parts, for which streamflow records for respective parts shown are published in reports on surface-water supply.

plete years were not processed by electronic computer but were analyzed as low-flow partial-record stations.

The reference period used for this study is the 29-year period 1929-57, because this was the longest period for which a representative number of records was available at the selected long-term stations and at the index stations. The annual minimum discharges such as given in table 6 are the lowest in each year beginning April 1 and ending the following March 31, so that the periods of low flow, which usually occur in the summer and fall, are included in the same year. The flow-duration sequences are for each year ending September 30 and beginning the preceding October 1.

\section{LOW-FLOW FREQUENCY ANALYSIS}

Annual minimum discharges from records which were not complete for the reference period 1929-57 were adjusted to the reference period so that the results from all records would be comparable. The smoothed low-flow frequency curves for the long-term stations that have complete records for the reference period were used as the basis for adjusting the low-flow fre- 
TABLE 6.-Lowest mean discharge, Pearl River at Jackson, Miss. [Data, in cubic feet per second, for indicated number of consecutive days in indicated year beginning April 1]

\begin{tabular}{|c|c|c|c|c|c|c|}
\hline Year & 7 days & 15 days & 30 days & 60 days & 120 days & 183 days \\
\hline $\begin{array}{l}1902 \ldots \\
1903 \\
1904 \\
1905\end{array}$ & $\begin{array}{r}158.6 \\
98.0 \\
80.0 \\
214.0\end{array}$ & $\begin{array}{r}178.3 \\
98.0 \\
84.3 \\
243.2\end{array}$ & $\begin{array}{r}199.3 \\
98.0 \\
89.5 \\
460.5\end{array}$ & $\begin{array}{l}231.2 \\
103.7 \\
105.9 \\
711.4\end{array}$ & $\begin{array}{l}452.5 \\
139.2 \\
167.9 \\
802.0\end{array}$ & $\begin{array}{l}444.5 \\
316.0 \\
534.6 \\
826.4\end{array}$ \\
\hline $\begin{array}{l}1906 \\
1907 \\
1908 \\
1909 \\
1910\end{array}$ & $\begin{array}{l}330.9 \\
153.6 \\
110.0 \\
130.0 \\
121.4\end{array}$ & $\begin{array}{l}390.5 \\
163.7 \\
113.3 \\
132.0 \\
134.0\end{array}$ & $\begin{array}{l}483.9 \\
178.5 \\
116.3 \\
153.7 \\
152.3\end{array}$ & $\begin{array}{l}584.0 \\
205.6 \\
140.9 \\
159.1 \\
187.6\end{array}$ & $\begin{array}{l}782.5 \\
348.8 \\
412.3 \\
208.8 \\
233.8\end{array}$ & $\begin{array}{r}2,854.2 \\
567.9 \\
777.0 \\
468.2 \\
942.1\end{array}$ \\
\hline $1911 \ldots$ & 97.1 & 98.7 & 105.7 & 146.9 & 393.7 & 684.2 \\
\hline $\begin{array}{l}1929 \ldots \\
1930\end{array}$ & $\begin{array}{l}143.3 \\
134.4\end{array}$ & $\begin{array}{l}164.8 \\
192.2\end{array}$ & $\begin{array}{l}211.0 \\
212.8\end{array}$ & $\begin{array}{l}409.1 \\
265.0\end{array}$ & $\begin{array}{l}615.2 \\
347.7\end{array}$ & $\begin{array}{r}1,069.3 \\
690.5\end{array}$ \\
\hline $\begin{array}{l}1931 \ldots \\
1932 . \\
1933 . \\
1934 \ldots \\
1935 \ldots\end{array}$ & $\begin{array}{l}114.3 \\
386.1 \\
244.0 \\
422.3 \\
161.1\end{array}$ & $\begin{array}{l}119.3 \\
424.0 \\
249.1 \\
482.1 \\
165.7\end{array}$ & $\begin{array}{l}120.7 \\
464.7 \\
272.1 \\
559.4 \\
189.5\end{array}$ & $\begin{array}{l}145.2 \\
679.9 \\
314.4 \\
726.7 \\
296.5\end{array}$ & $\begin{array}{l}669.5 \\
895.9 \\
507.0 \\
941.5 \\
349.1\end{array}$ & $\begin{array}{r}1,461.2 \\
1,124.0 \\
652.9 \\
1,688.6 \\
531.2\end{array}$ \\
\hline $\begin{array}{l}1936 \ldots \\
1937-\ldots \\
1938 \ldots \\
1939 \\
1940 \ldots\end{array}$ & $\begin{array}{r}97.6 \\
204.9 \\
146.1 \\
122.9 \\
209.7\end{array}$ & $\begin{array}{r}98.9 \\
225.6 \\
147.4 \\
126.6 \\
219.3\end{array}$ & $\begin{array}{l}103.0 \\
232.3 \\
154.7 \\
135.8 \\
282.8\end{array}$ & $\begin{array}{l}107.5 \\
376.1 \\
172.4 \\
153.8 \\
403.7\end{array}$ & $\begin{array}{l}157.2 \\
582.5 \\
276.9 \\
190.1 \\
766.0\end{array}$ & $\begin{array}{r}244.5 \\
796.8 \\
694.7 \\
364.9 \\
2,461.3\end{array}$ \\
\hline $\begin{array}{l}1941 \ldots \\
1942 \ldots \\
1943 \ldots \\
1944 \ldots \\
1945 \ldots\end{array}$ & $\begin{array}{r}219.6 \\
161.3 \\
86.9 \\
103.7 \\
177.9\end{array}$ & $\begin{array}{r}234.3 \\
173.5 \\
88.3 \\
110.5 \\
183.4\end{array}$ & $\begin{array}{r}295.4 \\
210.9 \\
91.7 \\
119.9 \\
196.3\end{array}$ & $\begin{array}{l}311.8 \\
310.8 \\
143.1 \\
150.9 \\
254.4\end{array}$ & $\begin{array}{l}515.4 \\
391.3 \\
175.0 \\
317.5 \\
329.0\end{array}$ & $\begin{array}{l}991.4 \\
585.9 \\
218.6 \\
426.2 \\
652.6\end{array}$ \\
\hline $\begin{array}{l}1946 \ldots \ldots \\
1947 \ldots \\
1948 \ldots \\
1949 \ldots \\
1950 \ldots\end{array}$ & $\begin{array}{l}205.0 \\
127.3 \\
172.6 \\
418.9 \\
556.7\end{array}$ & $\begin{array}{l}211.3 \\
130.3 \\
184.8 \\
423.7 \\
653.7\end{array}$ & $\begin{array}{l}229.8 \\
140.8 \\
247.8 \\
472.2 \\
827.1\end{array}$ & $\begin{array}{r}273.9 \\
184.7 \\
341.4 \\
591.6 \\
1,216.8\end{array}$ & $\begin{array}{r}1,073.2 \\
400.1 \\
492.2 \\
960.9 \\
1,427.1\end{array}$ & $\begin{array}{r}1,792.9 \\
748.6 \\
465.9 \\
1,288.6 \\
1,608.6\end{array}$ \\
\hline $\begin{array}{l}1951 \\
1952 \\
1953 \\
1954\end{array}$ & $\begin{array}{r}193.1 \\
97.4 \\
93.3 \\
80.0 \\
104.3\end{array}$ & $\begin{array}{r}198.3 \\
100.4 \\
96.7 \\
82.3 \\
109.1\end{array}$ & $\begin{array}{r}218.6 \\
102.5 \\
103.4 \\
91.6 \\
123.7\end{array}$ & $\begin{array}{l}249.8 \\
116.8 \\
109.3 \\
100.0 \\
173.8\end{array}$ & $\begin{array}{l}286.3 \\
178.5 \\
186.9 \\
158.2 \\
344.4\end{array}$ & $\begin{array}{l}401.8 \\
226.8 \\
404.5 \\
242.1 \\
518.4\end{array}$ \\
\hline $1956^{1} \ldots$ & $\begin{array}{r}87.0 \\
176.9\end{array}$ & $\begin{array}{r}92.2 \\
194.4\end{array}$ & $\begin{array}{l}101.6 \\
224.2\end{array}$ & $\begin{array}{l}119.8 \\
523.4\end{array}$ & $\begin{array}{l}143.8 \\
978.5\end{array}$ & $\begin{array}{r}231.8 \\
1,217.0\end{array}$ \\
\hline
\end{tabular}

1 Figures for 1956 are unpublished; they are adjusted for change in contents during filling of reservoir at city of Jackson waterworks.

quency curves at stations having shorter records. This adjusting was accomplished by relating the annual minimum discharges for each pair of stations as shown in figure 6 . Through these relations, the smoothed discharges at various recurrence intervals for the longterm stations were transferred to stations having the shorter records.

Each relation was based on the data for the period of concurrent years of record at the pair of stations being related. In figure 6 , for example, the period of concurrent record is 1939-57. The annual minimum discharges for each period of consecutive days were arrayed in order of magnitude and assigned order numbers. The arrayed 7-day low flows used for figure 6 are shown in table 8 . The relation of annual minimum discharge was based on arrayed data of annual minimum discharges for periods of $7,15,30,60,120$, and 183 days. Arrayed data define the unregressed relation between the annual minimum discharge at the two stations but give no indication of the degree of correlation.
The approximate degree of correlation was obtained by plotting the annual 7-day minimum discharges according to concurrent years as shown in the lower right-hand corner of figure 6 and by then computing the index of correlation as described by Searcy (1960, p. 84). If the index of correlation thus determined was less than 0.7 , the relation curve based on arrayed data was not considered to be suitable for adjusting low-flow frequency curves. In these instances the low-flow frequency curves were based on the observed record at the station, and the tabulated results are so noted.

If the index of correlation was 0.7 or more, the relation curve based on the arrayed annual minimum discharges was assumed to be the same-within acceptable limits of error-as the curve that would have been defined by record for the full reference period, and the relation curve was used to transpose low-flow frequency curves from the long-term station to an index station or from an index station to a shorter term station. The transposed curves, which represent the adjusted lowflow frequency curves for the shorter term station, were plotted as shown in figure 3 and used as the basis for the results summarized in table 3 .

Low-flow frequency results for partial-record stations and for stations having only a few years of continuous record are of a much lower order of accuracy than are similar results for the long-term stations because the relation curves are based on a smaller range in discharge and a smaller variety of experience.

Some of the shorter term stations were adjusted by their relations with two or more longer term stations. In such instances the average or the median of the values determined from the relations was used to position the frequency curves. For index stations that had complete or nearly complete records for the full reference period, the distribution of observed annual minimum discharges also was given some consideration in positioning the low-flow frequency curves.

\section{FLOW-DURATION ANALYSIS}

Flow-duration curves for the long-term stations were smoothed by comparison with the shape of the flowduration curves for other full-period stations.

Flow-duration data that were not complete for the reference period 1929-57 were extended to the reference period using the method described by Searcy (1959, p. 16). For each record shorter than the reference period, the duration curve for the reference period was obtained from a curve of relation between that record and a full-period record. As in low-flow frequency analysis, index-station records were used to bridge the gap between short and long records; and the short records that had been adjusted to the reference period were, in turn, used as index records for low-flow partial- 
TABLe 7.-Duration of daily flow, by water year, Pearl River at Jackson, Miss.

\begin{tabular}{|c|c|c|c|c|c|c|c|c|c|c|c|c|c|c|c|c|c|c|}
\hline Water year & \multicolumn{18}{|c|}{ Number of days when discharge, in cubic feet per second, was equal to or greater than indicated amount but less than amount in subsequent column } \\
\hline & 38 & & & & 26 & 27 & 29 & i & 31 & 21 & 0 & 34 & 31 & 8 & 15 & & & \\
\hline 1906 & & $\begin{array}{r}3 \\
42 \\
34\end{array}$ & $\begin{array}{r}4 \\
40 \\
28 \\
46\end{array}$ & $\begin{array}{r}1 \\
8 \\
18 \\
27 \\
14\end{array}$ & $\begin{array}{l}57 \\
32 \\
15 \\
11 \\
27\end{array}$ & $\begin{array}{l}53 \\
51 \\
17 \\
21 \\
52\end{array}$ & $\begin{array}{l}45 \\
37 \\
28 \\
35 \\
38\end{array}$ & $\begin{array}{l}61 \\
58 \\
38 \\
34 \\
59\end{array}$ & $\begin{array}{l}39 \\
22 \\
43 \\
16 \\
32\end{array}$ & $\begin{array}{r}31 \\
36 \\
29 \\
9 \\
16\end{array}$ & $\begin{array}{l}24 \\
31 \\
21 \\
14 \\
14\end{array}$ & $\begin{array}{l}17 \\
15 \\
23 \\
32 \\
28\end{array}$ & $\begin{array}{r}12 \\
17 \\
18 \\
22 \\
5\end{array}$ & $\begin{array}{r}6 \\
30 \\
30 \\
30\end{array}$ & $\begin{array}{l}16 \\
19 \\
38 \\
27\end{array}$ & $\begin{array}{l}3 \\
5 \\
5 \\
7 \\
7\end{array}$ & $\cdots$ & $\overline{1}$ \\
\hline 1911 & 2 & $\begin{array}{l}35 \\
42\end{array}$ & $\begin{array}{l}22 \\
12\end{array}$ & $\begin{array}{l}52 \\
21\end{array}$ & $\begin{array}{r}31 \\
6\end{array}$ & $\begin{array}{r}31 \\
7\end{array}$ & $\begin{array}{l}27 \\
12\end{array}$ & $\begin{array}{l}64 \\
35\end{array}$ & $\begin{array}{l}32 \\
15\end{array}$ & $\begin{array}{l}10 \\
24\end{array}$ & $\begin{array}{l}17 \\
36\end{array}$ & $\begin{array}{l}16 \\
54\end{array}$ & $\begin{array}{r}6 \\
28\end{array}$ & $\begin{array}{l}22 \\
28\end{array}$ & 37 & 7 & & \\
\hline 1929 & & $\begin{array}{l}7 \\
8\end{array}$ & $\begin{array}{l}49 \\
27\end{array}$ & $\begin{array}{l}37 \\
63\end{array}$ & $\begin{array}{l}38 \\
27\end{array}$ & $\begin{array}{l}32 \\
24\end{array}$ & $\begin{array}{l}37 \\
12\end{array}$ & $\begin{array}{l}36 \\
10\end{array}$ & $\begin{array}{l}34 \\
12\end{array}$ & $\begin{array}{l}20 \\
33\end{array}$ & $\begin{array}{l}23 \\
43\end{array}$ & $\begin{array}{l}25 \\
52\end{array}$ & 31 & $\begin{array}{r}6 \\
12\end{array}$ & $\begin{array}{l}5 \\
5\end{array}$ & $\begin{array}{l}9 \\
5\end{array}$ & & \\
\hline & & 47 & $\begin{array}{l}7 \\
2\end{array}$ & & $\begin{array}{l}30 \\
34\end{array}$ & $\begin{array}{l}36 \\
30\end{array}$ & $\begin{array}{l}25 \\
46\end{array}$ & $\begin{array}{l}31 \\
40\end{array}$ & $\begin{array}{l}49 \\
30\end{array}$ & $\begin{array}{l}41 \\
21\end{array}$ & $\begin{array}{r}56 \\
9\end{array}$ & $\begin{array}{l}18 \\
22\end{array}$ & $\begin{array}{r}5 \\
31\end{array}$ & $\begin{array}{r}8 \\
34\end{array}$ & 20 & $\cdots$ & & \\
\hline & & & $\cdots$ & $\begin{array}{r}2 \\
\mathbf{3 9}\end{array}$ & $\begin{array}{r}28 \\
22\end{array}$ & $\begin{array}{l}34 \\
48\end{array}$ & 24 & $\begin{array}{l}28 \\
65\end{array}$ & $\begin{array}{l}13 \\
55\end{array}$ & 14 & 48 & 58 & 65 & 22 & $\begin{array}{l}7 \\
4\end{array}$ & 16 & 4 & \\
\hline & & & $\begin{array}{l}7 \\
3\end{array}$ & $\begin{array}{l}29 \\
45\end{array}$ & $\begin{array}{l}58 \\
63\end{array}$ & $\begin{array}{l}31 \\
39\end{array}$ & $\begin{array}{l}18 \\
31\end{array}$ & $\begin{array}{l}32 \\
63\end{array}$ & $\begin{array}{l}33 \\
37\end{array}$ & $\begin{array}{l}35 \\
18\end{array}$ & $\begin{array}{l}61 \\
16\end{array}$ & $\begin{array}{l}31 \\
47\end{array}$ & $\begin{array}{r}19 \\
3\end{array}$ & 11 & & & & \\
\hline & & 21 & 62 & 46 & & & 21 & & 18 & 25 & 13 & & 14 & 8 & 5 & & & \\
\hline & 28 & $\begin{array}{l}21 \\
33\end{array}$ & $\begin{array}{l}37 \\
35\end{array}$ & $\begin{array}{l}23 \\
14\end{array}$ & & & $\begin{array}{l}24 \\
26\end{array}$ & $\begin{array}{l}30 \\
31\end{array}$ & $\begin{array}{l}27 \\
28\end{array}$ & $\begin{array}{l}12 \\
26\end{array}$ & $\begin{array}{r}9 \\
9 \\
28\end{array}$ & $\begin{array}{l}12 \\
22\end{array}$ & $\begin{array}{l}18 \\
10\end{array}$ & & $\begin{array}{r}15 \\
6\end{array}$ & $\begin{array}{l}6 \\
8 \\
8\end{array}$ & 5 & 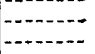 \\
\hline & & & $\begin{array}{l}22 \\
33\end{array}$ & $\begin{array}{l}33 \\
38\end{array}$ & $\begin{array}{l}31 \\
27\end{array}$ & ${ }_{24}^{17}$ & $\begin{array}{l}8 \\
8\end{array}$ & $\begin{array}{l}35 \\
35\end{array}$ & $\begin{array}{l}38 \\
33\end{array}$ & $\begin{array}{l}31 \\
42\end{array}$ & $\begin{array}{l}26 \\
32\end{array}$ & $\begin{array}{l}34 \\
28\end{array}$ & $\begin{array}{l}27 \\
21\end{array}$ & $\begin{array}{l}47 \\
13\end{array}$ & $\begin{array}{r}5 \\
22\end{array}$ & $\begin{array}{l}5 \\
9 \\
\end{array}$ & 6 & \\
\hline & & 21 & 19 & 27 & & & 29 & 2 & . & 21 & & & & & & 3 & & \\
\hline & & & 14 & 13 & & & 1 & 39 & $\begin{array}{r}29 \\
309\end{array}$ & & 33 & & & & & 11 & 2 & - \\
\hline & & & & & & & & & & 19 & & 27 & 44 & 16 & 17 & 3 & 5 & \\
\hline & & & 49 & $\begin{array}{l}01 \\
68\end{array}$ & 50 & 20 & $\begin{array}{r}50 \\
8\end{array}$ & 30 & 29 & 53 & 29 & 19 & 44 & 10 & $\mu t$ & .... & 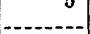 & \\
\hline & 99 & $\begin{array}{l}46 \\
67\end{array}$ & 22 & 38 & & & 17 & 9 & 20 & 2 & & 0 & 20 & 22 & 27 & 6 & & \\
\hline & $\begin{array}{l}31 \\
26\end{array}$ & $\begin{array}{l}67 \\
14\end{array}$ & $\begin{array}{l}18 \\
\mathbf{3 9}\end{array}$ & $\begin{array}{l}16 \\
24\end{array}$ & $\begin{array}{l}35 \\
24\end{array}$ & $\begin{array}{l}33 \\
39\end{array}$ & $\begin{array}{l}31 \\
17\end{array}$ & $\begin{array}{l}28 \\
33\end{array}$ & $\begin{array}{l}25 \\
36\end{array}$ & $\begin{array}{l}21 \\
33\end{array}$ & $\begin{array}{l}15 \\
24\end{array}$ & $\begin{array}{l}27 \\
26\end{array}$ & $\begin{array}{r}18 \\
9\end{array}$ & 9 & 5 & 7 & & - \\
\hline & 14 & $\begin{array}{l}42 \\
36\end{array}$ & $\begin{array}{l}\mathbf{5 7} \\
40\end{array}$ & 33 & $\begin{array}{l}29 \\
14\end{array}$ & $\begin{array}{r}43 \\
7\end{array}$ & $\begin{array}{l}26 \\
46\end{array}$ & 22 & $\begin{array}{r}6 \\
33\end{array}$ & 13 & 6 & 10 & 10 & 27 & 23 & 5 & & \\
\hline
\end{tabular}

TABLE 8.-Seven-day minimum discharges in order of magnitude, Pearl River at Jackson and Noxubee River at Macon, Miss., climatic years $1939-57$

\begin{tabular}{|c|c|c|}
\hline \multirow[b]{2}{*}{ Order } & \multicolumn{2}{|c|}{$\begin{array}{l}\text { Discharge, in cubic feet } \\
\text { per second }\end{array}$} \\
\hline & $\begin{array}{l}\text { Pearl River } \\
\text { at Jackson, } \\
\text { Miss. }\end{array}$ & $\begin{array}{c}\text { Noxubee } \\
\text { River at } \\
\text { Macon, Miss. }\end{array}$ \\
\hline 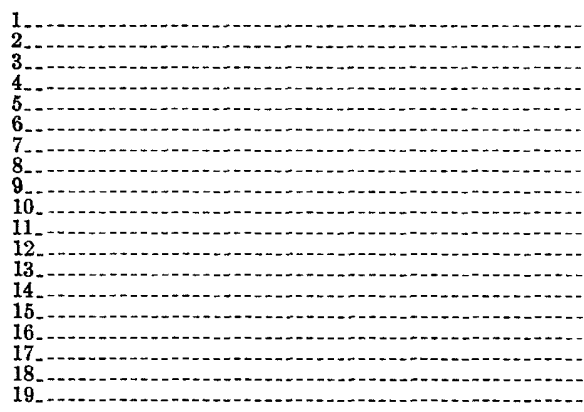 & $\begin{array}{r}80.0 \\
86.9 \\
87.0 \\
93.3 \\
97.4 \\
103.7 \\
104.3 \\
122.9 \\
127.3 \\
161.3 \\
172.6 \\
176.9 \\
177.9 \\
193.1 \\
205.0 \\
209.7 \\
219.6 \\
418.9 \\
556.7\end{array}$ & $\begin{array}{l}24.6 \\
25.3 \\
27.4 \\
29.1 \\
29.1 \\
34.3 \\
37.6 \\
38.1 \\
38.9 \\
43.6 \\
44.3 \\
52.9 \\
53.4 \\
56.1 \\
60.7 \\
65.6 \\
66.3\end{array}$ \\
\hline
\end{tabular}

record stations. Daily-discharge stations having less than 5 years of record during the reference period were analyzed as partial-record stations.

An example of a relation curve used to adjust the flow-duration curve for a record shorter than the reference period is given in figure 6 . The curve is defined by discharges having the same percentage duration at both stations during the period of concurrent record, and it is used to transpose the referenceperiod discharge for selected percentages duration from the long-term station to the short-term station. The lower half of the relation cruve for flow-duration data has the same general shape as that for the arrayed data but differs from it somewhat. The two curves tend to converge at extremely low discharges. Discharges for selected duration points picked from the relation curves were used to define flow-duration curves such as shown in figure 4, and the results are sum- 


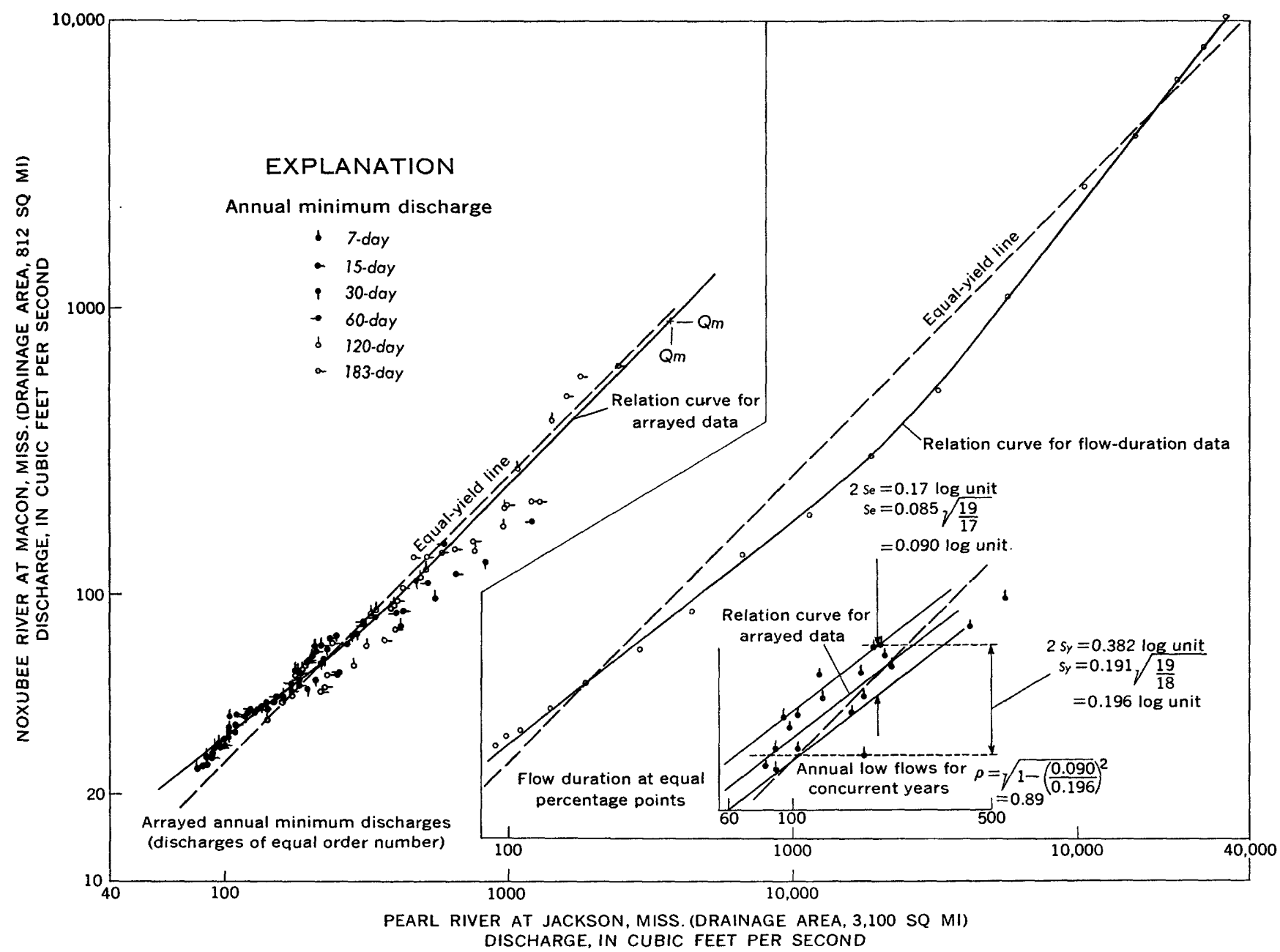

Figure 6.-Graphs showing relation of annual low flows and flow duration, Noxubee River at Macon and Pearl River at Jackson, Miss., $1939-57$.

marized in table 4. As in low-flow frequency analysis, the results for the partial-record stations are of a much lower order of accuracy than are those for long-term gaging stations.

The percentages corresponding to the selected class limits, such as are shown at the bottom of table 7 , are rarely the same for any two records and therefore cannot be used in defining relation curves such as those shown in figure 6 . To obtain the discharge for the same percentages of duration at all stations, the observed-duration data for each station were first plotted according to the percentages as determined by the computer, and the discharges at selected equalpercentage points were then taken from these curves.

\section{DRAFT-STORAGE RELATIONS}

The discharges given in tables 2, 3, and 4 are indicacations of the natural flow of the streams. To provide for drafts greater than the natural flow, storage must be provided. The amount of such storage and the frequency with which it is required provide a basis for obtaining an economic balance between the cost of the storage and the loss resulting from an insufficient supply at periodic intervals. The low-flow frequency data in table 3 were used to estimate the draft that may be maintained from specified amounts of storage.

The procedure used to estimate storage requirements from the data in table 3 is as follows:

1. Convert the discharge to cubic feet per second per square mile.

2. Plot low-flow frequency curves for the 10-year and 20 -year recurrence intervals for each of the 78 gaging-station records, as illustrated in figure 7.

3. Compute the average rate of release, in cubic feet per second per square mile, over periods of selected length from a specified volume of storage; and plot a curve of rate of release against days duration for each volume of storage, as illustrated in figure 8 . The volumes of storage used in this report are $0,5,15,30,60$, and 90 acre-feet per square mile. 


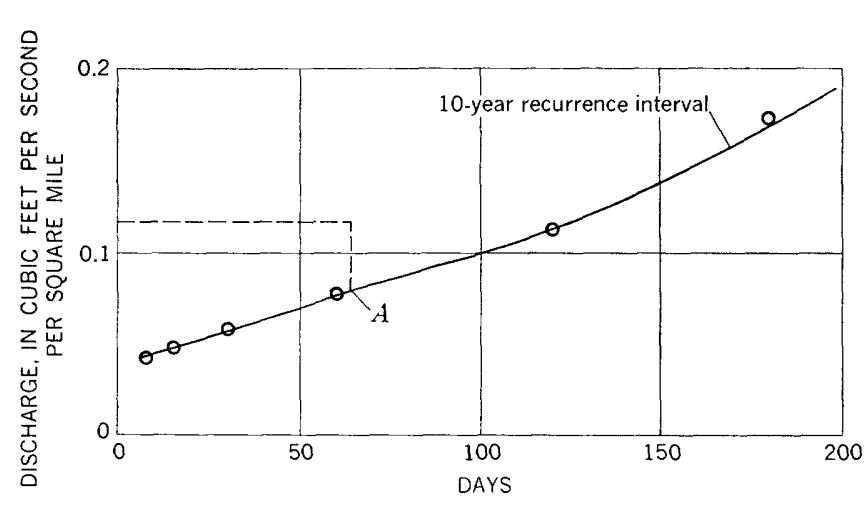

FIGURE 7.-Graph showing annual low flow, in cubic feet per second per square mile for indicated number of days at 10-year recurrence interval, Sipsey River at Moores Bridge, Ala. Circles represent natural flow computed from data in table 3.

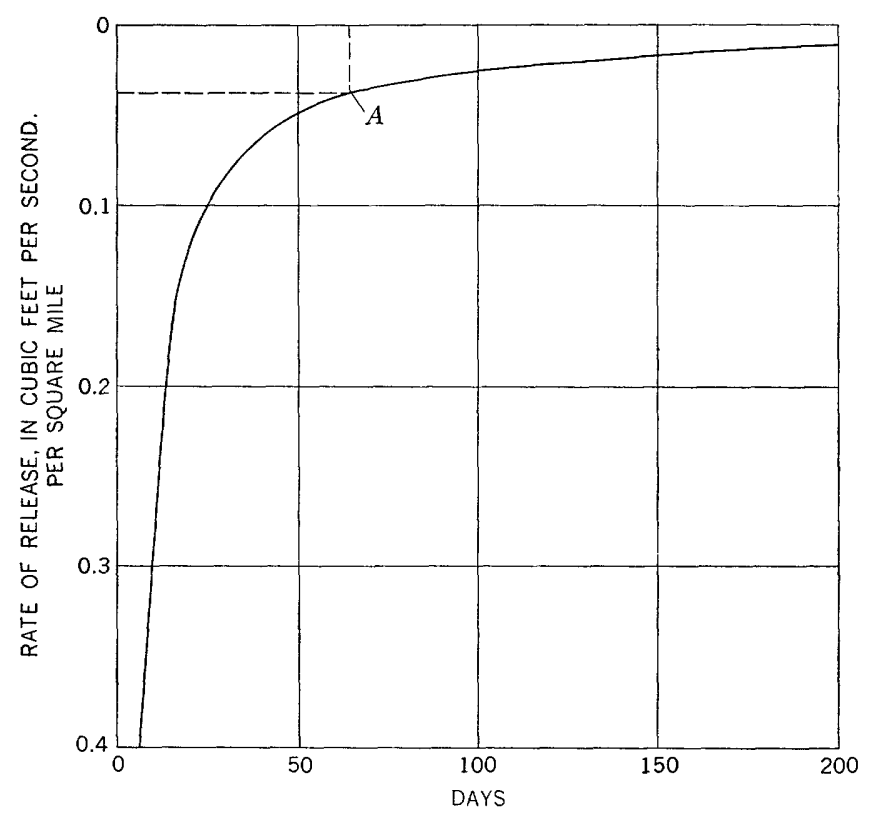

Figure 8.-Graph showing average release, in cubic feet per second per square mile, from a volume of storage of 5 acre-feet per square mile for indicated number of days.

4. Determine the allowable draft for each specified volume of storage as being the smallest sum of the rate of natural discharge at the station and the rate of release available from storage.

Step 4 of the procedure is illustrated in figures 7 and 8 . In the figures, a critical period of 64 days (point $A$ ) represents the point at which the rates of discharge added together produce the smallest sum. The ordinates giving these rates of discharge are 0.077 cfs per sq $\mathrm{mi}$ in figure 7 (natural flow) and $0.039 \mathrm{cfs}$ per sq $\mathrm{mi}$ in figure 8 (releases from storage). Thus, storage of 5 acre-feet per square mile upstream from the gaging station on Sipsey River at Moores Bridge, Ala., will provide for a total draft of $0.116 \mathrm{cfs}$ per sq $\mathrm{mi}$, and the storage may be expected to be insufficient to supply this rate of flow once in 10 years on a longterm average. Similar computations were made for each of the 78 gaging stations for storage of $0,5,15$, 30,60 , and 90 acre-feet per square mile for recurrence intervals of 10 and 20 years. Because of the limited definition of the low-flow frequency curves for some stations, however, complete results could not be obtained for all amounts of storage. For large amounts of storage, the sum of the discharges in figures 7 and 8 at some stations continued to decrease from 7 days to 200 days, so that it was impossible with the low-flow frequency curves available to determine the draft that may be made. Low-flow frequency for periods longer than 183 days are outside the scope of this report.

Draft-storage data for additional recurrence intervals may be computed by plotting frequency curves for the desired recurrence intervals and by then computing the allowable draft for selected amounts of storage as described in the previous paragraph.

To provide a means for estimating the storage required for various drafts at other sites, the storagerequired frequency data computed as described in the preceding paragraphs are related to the median annual 7-day (7-day 2-year) low flows in figures 9 and 10 . This index of low flow, which is the same as that used in the section on "factors affecting low flow," is given in table 2 for 219 sites in the study area. For other sites, the index usually can be estimated by making a few measurements of low flow and relating the measured discharge to the concurrent discharge at the nearest site listed in table 2 (Searcy, 1959, p. 20).

As a result of the limitation described above, the number of points available to define the curves in the lower half of figures 9 and 10 range from 15 for the 90 acre-feet at the 20-year recurrence interval to 78 for 0 and 5 acre-feet at the 10- and 20-year recurrence intervals. The scatter of the circles in the lower graph of figure 9 for a storage of 30 acre-feet per square mile is typical of the scatter of the points that define other curves in the two lower graphs. The plottings show approximate standard errors of about 10 percent. The curves in the upper part of the figures are based on the curves in the lower part.

The curves of zero storage in figures 9 and 10 represent the 7-day low flow for the 10-year or the 20-year recurrence interval and thus neglect the small amount of storage that will be required to regulate the 7-day flow within the minimum. None of the curves include reservoir losses or losses in conveyance of water from the storage facility to the point of utilization. Furthermore, a bias of about 10 percent that results from using low-flow frequency curves to compute storage requirements also has been neglected. As the losses and the bias both tend to make the computed amount of storage smaller than it should be, allowance for these must be included in project design. The areal draft- 


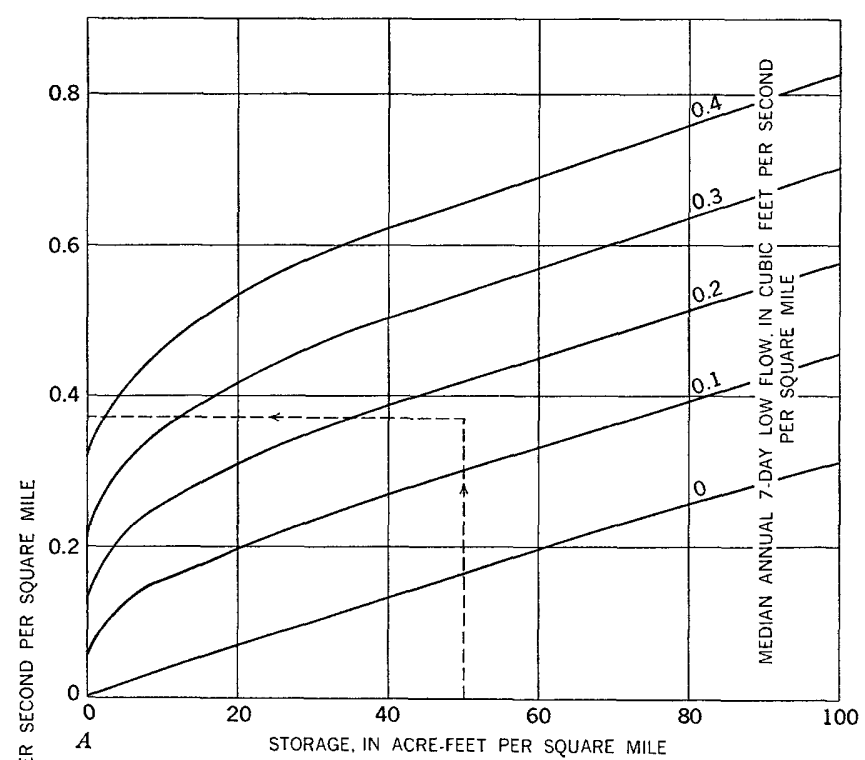

采 $A$ STORAGE, IN ACRE-FEET PER SQUARE MILE
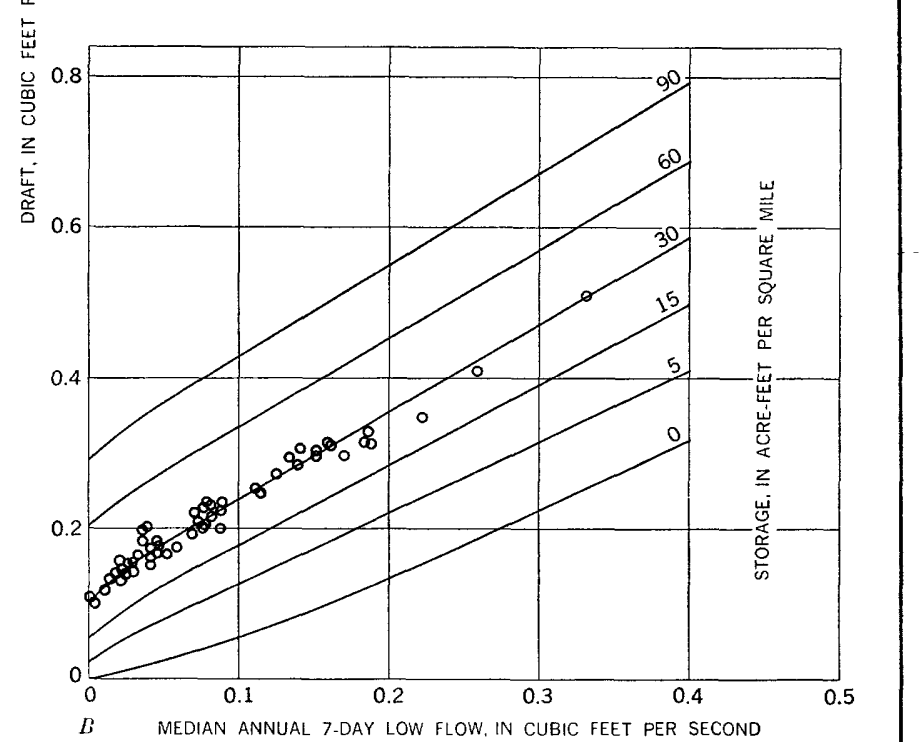
PER SOUARE MILE

FigURe 9.-Graphs showing areal draft-storage relations for a 10-year recurrence interval as a function of the median annual 7-day low flow, for storage of $0,5,15,30,60$, and 90 acre-feet per square mile for the Mississippi embayment in Mississippi and Alabama. Dashed lines in $A$ demonstrate illustrative problem given in text. Circles in $B$ represent drafts for a storage of 30 acre-feet per square mile at 73 streamgaging stations.

storage relations, therefore, should be used only for obtaining preliminary estimates of draft-storage requirements at partial-record sites and for making comparisons between stations. More detailed studies, using the data in table 3 if available for the specific location, should be made in connection with design of specific projects.

Values for median annual 7-day low flow as high as 2.0 cfs per sq mi are shown in table 2. However, because of the limitations of the data on which the curves in figures 9 and 10 are based, the curves should

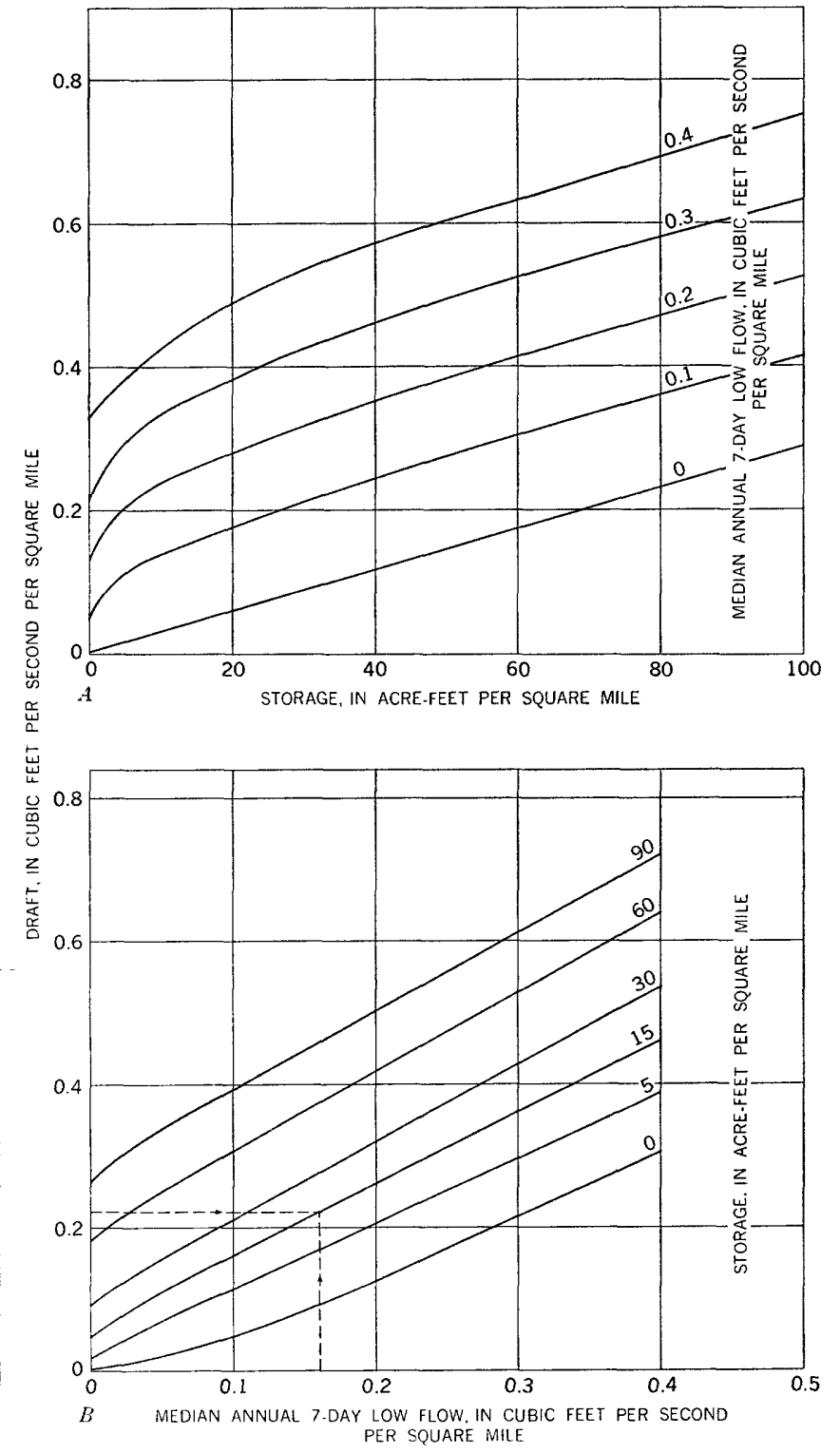

FIGURE 10.-Graphs showing areal draft-storage relations for a 20-year recurrence interval as a function of the median annual 7-day low flow, for storage of $0,5,15$, 30,60 and 90 acre-feet per square mile for the Mississippi embayment in Mississippi and Alabama. Dashed lines in $B$ demonstrate illustrative problem given in text.

not be extrapolated beyond the limits to which they are shown.

The storage required for a specified draft with a chance of its being insufficient on an average of once in 10 or once in 20 years can be determined by entering figures 9 and 10 with the median annual 7-day low flow for the stream at the point of utilization. Having the median annual 7-day low flow as abscissa and the storage to be provided as a parameter, the diagram in the lower half of figures 9 and 10 gives the specified draft. If the required draft is known, the diagram in the upper half of figures 9 and 10 can be used to determine the amount of storage required. 
Illustrative problem 1.-Let it be assumed that a proposal is made to build a manufacturing plant on Luxapalila Creek at Steens, Miss., which will require a minimum flow of $68 \mathrm{cfs}$ for operation; for economic reasons, the flow should not drop below this discharge more of ten than once in 20 years on a long-term average. How much storage will be required to maintain this flow for this frequency?

1. From table 2, for Luxapalila Creek at Steens (station 2B4430), obtain the median annual 7-day low flow (7-day 2-year), which is $0.16 \mathrm{cfs}$ per sq $\mathrm{mi}$, and the drainage area, which is 309 square miles.

2. Divide $68 \mathrm{cfs}$ by 309 square miles to obtain a required draft of $0.22 \mathrm{cfs}$ per sq mi.

3. Use the lower graph of figure 10 . The abscissa being $0.16 \mathrm{cfs}$ per sq mi and the ordinate being $0.22 \mathrm{cfs}$ per sq $\mathrm{mi}$, the estimated storage required is 15 acre-feet per square mile or 4,640 acre-feet. This amount plus both 10 percent for bias and an additional amount for reservoir and conveyance losses would be required to provide the desired draft and would be insufficient at average intervals of 20 years.

It it is desired to estimate the maximum draft that may be made from a specified amount of available storage, the available storage must first be adjusted by estimates of both reservoir and conveyance losses and a bias of 10 percent, and then the drafts that may be expected at the point of utilization can be determined.

Illustrative problem 2.- - Let it be assumed that demands for water at Steens, Miss., are such that they greatly exceed the natural flow of Luxapalila Creek, and let it be assumed also that upstream from Steens a total storage of 17,900 acre-feet could be developed or made available for supplementing low flows. What draft at Steens can be maintained by this storage if a deficiency once in 10 years can be tolerated?

1. From table 2, for Luxapalila Creek at Steens, Miss. (station 2B4430), obtain the drainage area, which is 309 square miles, and the median annual 7-day low flow (7-day 2-year), which is $0.16 \mathrm{cfs}$ per sq mi.

2. Estimate the annual reservoir and conveyance losses and deduct these amounts from the total storage. For the purpose of this problem, the total of reservoir and conveyance losses during a dry year and 10 percent bias are estimated as 2,500 acrefeet. Then, the net storage available for use at Steens is 17,900 acre_feet minus 2,500 acre-feet, or 15,400 acre-feet.

3. Divide the net storage by the drainage area to obtain the net acre-feet per square mile available at Steens:

$$
\frac{15,400}{309}=50 \text { acre-feet per square mile }
$$

4. Use the upper graph of figure 9. The abscissa being 50 acre-feet per square mile and the parameter being 0.16 , interpolate between curves for a median annual 7-day low flows of 0.1 and 0.2 cfs per sq mi, and read as ordinate the draft of 0.37 cfs per sq mi. For 309 square miles, this would give $114 \mathrm{cfs}$ as the allowable draft that would deplete the storage once in 10 years on a long-term average. As soon as the storage was depleted, the available flow would drop to the natural inflow, which for this stream is 0.09 cfs per sq $\mathrm{mi}$ or $29 \mathrm{cfs}$ at a 10-year recurrence interval, unless the allowable draft were curtailed to less than $114 \mathrm{cfs}$ as the drought developed and as the amount of water in storage became dangerously low.

Storage and draft data in figures 9 and 10 can be converted to other units by using the following conversion equivalents:

1 acre-foot $=0.326$ million gallons $=0.504 \mathrm{cfs}$-day

$1 \mathrm{cfs}-$ day $=1.983$ acre-feet $=0.646$ million gallons

1 million gallons per square mile $=1.548$ cfs-days per square mile $=3,070$ acre-feet per square mile

\section{QUALITY OF THE WATER}

\section{By W. J. WeLborne}

As a part of the low-flow studies in the Mississippi embayment in Mississippi and Alabama, samples of water were collected at 30 gaging sites during periods of low flow. The analyses of these samples were used to determine similarities and differences in the chemical quality of the waters at various sites during the low-flow periods and to relate the quality of the water insofar as possible to the geologic environment.

The 30 most nearly ideal gaging sites were selected from the network of stations used in the low-flow study according to the following criteria: (1) The drainage area above the site should be small, (2) the area drained above the site should be in one geologic unit, and (3) the stream above the site should not be polluted. The drainage areas above the selected sites ranged from 6 to 524 square miles; only 13 had drainage areas in only one geologic unit; and the water in the streams at all 30 sites seemed to be free of manmade pollution. The quality of water in one stream apparently was affected by the discharge from a flowing well upstream from the sampling site.

Fifty-eight water samples were collected and analyzed-two each from 28 of the gaging sites and one from each of the other 2 sites. For comparison of the chemical quality of the waters, a diagram of each 
analysis was made based on a modification of a system suggested by Stiff (1951). These diagrams show, in graphic form, the relation, in equivalents per million, between the five principal cations and the five principal anions in the water sampled. Plate 3 shows the patterns for the chemical analysis of water collected at each of the 30 gaging sites, the location of the sampling sites, and the symbols for the geologic unit or units contributing to the low flow of the streams. Only one pattern is shown at each of 27 sites. At 25 of these sites, the chemical composition of the two samples collected months apart is almost identical; for sites 2B4325 and 7-2830, only one sample of water was collected and analyzed. At each of the other three sites, separate patterns are shown for each sample analyzed. Table 9 shows the chemical analysis of each sample.

All water samples were collected during periods of low streamflow so that the water in the streams would be primarily ground-water discharge. Most of the samples were collected during flows that are exceeded at least 70 percent of the time. Although the analyses of water from streams draining the same geologic units, but collected at different sites, did not always compare closely, water from the same site, collected months apart and at different discharge rates, generally had only minor variations in mineral content.

It was anticipated that, from the analysis of the water, one could relate the quality of water in a stream at low flow to the geologic unit contributing the flow. However, this is not possible in the area of study because the variations in mineral content between water from one unit and water from an adjacent unit are not always sufficient to characterize each unit. The smallness of the variations is due in part to the brevity of time during which the water remains in or moves through a unit. The water apparently is discharged to the stream within a short distance from the place where it enters the geologic unit, and the duration of contact with the unit is not sufficient for the water to have the same chemical composition as it would have after prolonged contact with the aquifer material. Local variations in the lithologic characteristics of a unit, the presence or absence of overlying terrace or alluvial material, and the orientation of the drainage basin all contribute to variations in the chemical quality of water presumably coming from the same geologic unit.

Because strata underlying the Mississippi embayment are composed of many different materials, the dissolvedsolids content of the low-flow surface waters ranged from $288 \mathrm{ppm}$ (parts per million) in Big Creek at Wedgeworth, Ala., to $11 \mathrm{ppm}$ in Bull Mountain Creek at Tremont, Miss. One sample of water from the stream draining the Quaternary alluvium contained $0.3 \mathrm{ppm}$ of fluoride, and one from the stream draining the Tallahatta Formation and the Winona and Sparta Sands contained $0.4 \mathrm{ppm}$. Other water sampled in this part of the embayment had a fluoride content of not more than $0.2 \mathrm{ppm}$. Except for the two samples from Big Creek near Wedgeworth, Ala., only five samples had a chloride content between 10 and $20 \mathrm{ppm}$. The remaining 51 samples had less than $8 \mathrm{ppm}$ of chloride. Iron concentration ranged from 0.00 to $1.4 \mathrm{ppm}$, most waters containing less than $0.3 \mathrm{ppm}$. The $\mathrm{pH}$ of the samples ranged from 6.2 to 7.5 , but most results fell between 6.5 and 7.2. Color in the surface water ranged from 4 to 50. The higher values probably were due to organic materials leached from vegetation. The source and significance of dissolved mineral constituents and properties of water are shown in table 10.

Water draining from the Quaternary area is the calcium bicarbonate type (table 9) which is characteristic of most water obtained from these deposits in the Mississippi embayment. This is as expected, because most of the fill of the Mississippi embayment trough above the Tertiary units is material containing calcium. carbonate as a principal soluble constituent.

The Cockfield Formation and Sparta Sand of Tertiary age crop out just east of the Quaternary alluvium. Water from these formations has a lower dissolvedsolids content and a slightly higher sodium content percentagewise than does water from the Quaternary alluvium. The calcium, magnesium, and bicarbonate content of the water from these two Tertiary units probably is affected by the loess mantle overlying a large part of the area.

Water from the Winona Sand has a dissolved-solids content of about $130 \mathrm{ppm}$, whereas the water from the Cockfield Formation and Sparta Sand has a dissolvedsolids content of about $60 \mathrm{ppm}$ and water from the Quaternary deposits has a dissolved-solids content of about $100 \mathrm{ppm}$. The higher dissolved-solids content of water from Winona Sand is principally due to higher concentrations of sodium, sulfate, and chloride.

Analyses of water from streams whose drainage basins are entirely in the Tallahatta Formation indicate that the dissolved-solids content of water discharged by this formation is low; the dissolved solids range from 14 to $25 \mathrm{ppm}$. Water from streams whose drainage basins are in both the Tallahatta and Wilcox Formations generally has a dissolved-solids content intermediate between that of water from the Tallahatta Formation and that of water from the Wilcox deposits. The dissolved-solids content of water from streams draining Wilcox deposits ranges from 32 to $56 \mathrm{ppm}$.

With the exception of three samples collected at stations 7-2820 and 7-2830, water from streams draining Porters Creek Clay and the Wilcox is similar in 
TABLE 9.-Chemical analyses of low-flow surface waters in the Mississippi embayment in Mississippi and Alabama

\begin{tabular}{|c|c|c|c|c|c|c|c|c|c|c|c|c|c|c|c|c|c|c|c|}
\hline \multirow[b]{3}{*}{$\begin{array}{l}\text { Geologic units in drainage basin } \\
\text { above sampling station }\end{array}$} & \multirow{3}{*}{$\begin{array}{c}\text { Date } \\
\text { sampled }\end{array}$} & \multirow{3}{*}{$\begin{array}{c}\text { Dis- } \\
\text { charge } \\
\text { (cfs) }\end{array}$} & \multicolumn{14}{|c|}{ Parts per million } & \multirow{3}{*}{$\begin{array}{c}\text { Spe- } \\
\text { cific } \\
\text { con- } \\
\text { duct- } \\
\text { ance } \\
\text { (mi- } \\
\text { cro- } \\
\text { mhos } \\
\text { at } \\
25^{\circ} \\
\text { C) }\end{array}$} & \multirow{3}{*}{$\mathrm{pH}$} & \multirow{3}{*}{ Color } \\
\hline & & & \multirow{2}{*}{$\begin{array}{r}\text { Silica } \\
\left(\mathrm{SiO}_{2}\right)\end{array}$} & \multirow[b]{2}{*}{$\underset{(\mathrm{Fe})}{\text { Iron }}$} & \multirow[b]{2}{*}{$\underset{(\mathbf{C a})}{\text { Cal- }}$} & \multirow[b]{2}{*}{$\begin{array}{c}\text { Mag- } \\
\text { ne- } \\
\text { sium } \\
(\mathrm{Mg})\end{array}$} & \multirow[b]{2}{*}{$\begin{array}{c}\text { Sodi- } \\
\text { um } \\
(\mathrm{Na})\end{array}$} & \multirow[b]{2}{*}{$\begin{array}{c}\text { Po- } \\
\text { tas- } \\
\text { sium } \\
(\mathrm{K})\end{array}$} & \multirow[b]{2}{*}{$\begin{array}{l}\text { Bicar- } \\
\text { bonate } \\
\left(\mathrm{HCO}_{3}\right)\end{array}$} & \multirow[b]{2}{*}{$\begin{array}{c}\text { Sul- } \\
\text { fate } \\
\left(\mathrm{SO}_{4}\right)\end{array}$} & \multirow[b]{2}{*}{$\begin{array}{l}\text { Chlo- } \\
\text { ride } \\
\text { (Cl) }\end{array}$} & \multirow[b]{2}{*}{$\begin{array}{l}\text { Fluo- } \\
\text { ride } \\
(\mathrm{F})\end{array}$} & \multirow[b]{2}{*}{$\begin{array}{c}\mathrm{Ni}- \\
\text { trate } \\
\left(\mathrm{NO}_{3}\right)\end{array}$} & \multirow{2}{*}{$\begin{array}{c}\text { Dis- } \\
\text { solved } \\
\text { solids } \\
\text { (calch- } \\
\text { lated } \\
\text { from } \\
\text { deter- } \\
\text { mined } \\
\text { con- } \\
\text { stit- } \\
\text { uents) }\end{array}$} & \multicolumn{2}{|c|}{$\begin{array}{l}\text { Hardness } \\
\text { as } \mathrm{CaCO}_{3}\end{array}$} & & & \\
\hline & & & & & & & & & & & & & & & $\begin{array}{c}\text { Cal- } \\
\text { cium, } \\
\text { mag- } \\
\text { ne- } \\
\text { sium }\end{array}$ & $\begin{array}{c}\text { Non- } \\
\text { car- } \\
\text { bon- } \\
\text { ate }\end{array}$ & & & \\
\hline \multirow{6}{*}{$\begin{array}{c}\text { Pottsville Formation and Tusca- } \\
\text { loosa Group }\end{array}$} & \multicolumn{19}{|c|}{ 2B4325.-Bull Mountain Creek at Tremont, Itawamba County, Miss. (drainage area, 120 square miles) } \\
\hline & $5-3-60$ & 46. 2 & 2.7 & 0.00 & 1.6 & 0.2 & 0.8 & 0.2 & 8 & 0.0 & 1.8 & 0.0 & 0.4 & 11 & 5 & 0 & 18 & 6.3 & $\boldsymbol{T}$ \\
\hline & \multicolumn{19}{|c|}{ 2B4420.-Luxapalila Creek near Fayette, Fayette County, Ala. (drainage area, 127 square miles) } \\
\hline & $\begin{array}{r}12-8-59 \\
6-14-60\end{array}$ & $\begin{array}{l}98 \\
80\end{array}$ & $\begin{array}{l}3.2 \\
5.5\end{array}$ & $\begin{array}{r}0.00 \\
.00\end{array}$ & $\begin{array}{l}1.1 \\
1.1\end{array}$ & $\begin{array}{r}0.9 \\
.8\end{array}$ & $\begin{array}{l}1.8 \\
1.9\end{array}$ & $\begin{array}{r}0.6 \\
.5\end{array}$ & $\begin{array}{l}8 \\
6\end{array}$ & $\begin{array}{l}2.4 \\
2.0\end{array}$ & $\begin{array}{l}2.0 \\
2.5\end{array}$ & $\begin{array}{r}0.0 \\
.0\end{array}$ & $\begin{array}{l}0.3 \\
2.0\end{array}$ & $\begin{array}{l}16 \\
19\end{array}$ & $\begin{array}{l}6 \\
6\end{array}$ & $\begin{array}{l}0 \\
1\end{array}$ & $\begin{array}{l}23 \\
23\end{array}$ & $\begin{array}{l}6.1 \\
6.6\end{array}$ & $\frac{4}{8}$ \\
\hline & & & 2B443 & 30.- $-\mathbf{L} \mathrm{t}$ & Ixapalil & la Cree & $\mathbf{k}$ at $\mathrm{S}$ & teens, & Lowndes & Count & ty, Mis & s. (dra & inage ar & ea, $309 \mathrm{sc}$ & quare $\mathrm{r}$ & miles) & & & \\
\hline & $\begin{array}{r}11-4-59 \\
7-8-60\end{array}$ & $\begin{array}{l}107 \\
76.3\end{array}$ & $\begin{array}{l}5.2 \\
4.9\end{array}$ & $\begin{array}{r}0.27 \\
.04\end{array}$ & $\begin{array}{l}1.9 \\
1.9\end{array}$ & $\begin{array}{r}0.6 \\
.6\end{array}$ & $\begin{array}{l}1.5 \\
1.4\end{array}$ & $\begin{array}{r}1.0 \\
.7\end{array}$ & $\begin{array}{r}11 \\
9\end{array}$ & $\begin{array}{l}0.2 \\
1.2\end{array}$ & $\begin{array}{l}2.8 \\
2.2\end{array}$ & $\begin{array}{r}0.0 \\
.1\end{array}$ & $\begin{array}{r}0.6 \\
.4\end{array}$ & $\begin{array}{l}20 \\
18\end{array}$ & 7 & $\begin{array}{l}0 \\
0\end{array}$ & $\begin{array}{l}33 \\
26\end{array}$ & $\begin{array}{l}5.2 \\
6.4\end{array}$ & $\begin{array}{l}40 \\
20\end{array}$ \\
\hline \multirow{6}{*}{ Tuscaloosa Group } & \multicolumn{19}{|c|}{ 2B4390.5.-Bogue Creek near Sulligent, Lamar County, Ala. (drainage area, 13.3 square miles) } \\
\hline & $\begin{array}{r}12-9-59 \\
6-14-60\end{array}$ & $\begin{array}{r}13.1 \\
8.5\end{array}$ & $\begin{array}{l}2.3 \\
4.9\end{array}$ & $\begin{array}{r}0.00 \\
.00\end{array}$ & $\begin{array}{r}2.2 \\
.5\end{array}$ & $\begin{array}{l}0.5 \\
1.1\end{array}$ & $\begin{array}{l}0.8 \\
1.2\end{array}$ & $\begin{array}{r}0.4 \\
.2\end{array}$ & $\begin{array}{l}8 \\
6\end{array}$ & $\begin{array}{r}0.2 \\
.2\end{array}$ & $\begin{array}{l}2.0 \\
2.2\end{array}$ & $\begin{array}{r}0.0 \\
.0\end{array}$ & $\begin{array}{l}0.3 \\
1.3\end{array}$ & $\begin{array}{l}13 \\
15\end{array}$ & $\begin{array}{l}8 \\
6\end{array}$ & $\begin{array}{l}1 \\
0\end{array}$ & $\begin{array}{l}23 \\
21\end{array}$ & $\begin{array}{l}6.0 \\
6.7\end{array}$ & $\frac{4}{7}$ \\
\hline & \multicolumn{19}{|c|}{ 2B4451.-Bear Creek near Gordo, Pickens County, Ala. (drainage area, 22.2 square miles) } \\
\hline & $\begin{array}{r}12-9-59 \\
6-14-60\end{array}$ & $\begin{array}{l}8.3 \\
3.4\end{array}$ & $\begin{array}{l}1.8 \\
4.7\end{array}$ & $\begin{array}{r}0.00 \\
.21\end{array}$ & $\begin{array}{l}0.6 \\
2.2\end{array}$ & $\begin{array}{r}1.5 \\
.8\end{array}$ & $\begin{array}{l}1.7 \\
1.5\end{array}$ & $\begin{array}{r}0.4 \\
.3\end{array}$ & $\begin{array}{l}8 \\
9\end{array}$ & $\begin{array}{r}0.6 \\
.0\end{array}$ & $\begin{array}{l}3.5 \\
3.0\end{array}$ & $\begin{array}{r}0.0 \\
.1\end{array}$ & $\begin{array}{l}0.2 \\
1.6\end{array}$ & $\begin{array}{l}14 \\
19\end{array}$ & $\begin{array}{l}8 \\
9\end{array}$ & $\frac{1}{2}$ & $\begin{array}{l}26 \\
29\end{array}$ & $\begin{array}{l}6.1 \\
6.6\end{array}$ & $\begin{array}{r}5 \\
35\end{array}$ \\
\hline & & & 2B4654 & 4.95.-1 & glliotts & Creek & near $\mathrm{n}$ & Mound & Iville, Hal & le Cou & nty, A & la. (dra & ainage a & rea, 31.2 & equare & miles) & & & \\
\hline & $\begin{array}{r}12-3-59 \\
6-17-60\end{array}$ & $\begin{array}{l}27.6 \\
15.5\end{array}$ & $\begin{array}{l}4.5 \\
4.6\end{array}$ & $\begin{array}{r}0.09 \\
.00\end{array}$ & $\begin{array}{l}2.0 \\
2.2\end{array}$ & 0.1 & $\begin{array}{l}1.4 \\
1.3\end{array}$ & $\begin{array}{r}0.5 \\
.4\end{array}$ & $\begin{array}{l}8 \\
8\end{array}$ & $\begin{array}{r}0.8 \\
.2\end{array}$ & $\begin{array}{l}3.0 \\
2.2\end{array}$ & $\begin{array}{r}0.0 \\
.1\end{array}$ & $\begin{array}{l}0.2 \\
1.3\end{array}$ & $\begin{array}{l}17 \\
16\end{array}$ & $\begin{array}{l}6 \\
6\end{array}$ & $\begin{array}{l}0 \\
0\end{array}$ & $\begin{array}{l}20 \\
23\end{array}$ & $\begin{array}{l}6.0 \\
6.5\end{array}$ & $\begin{array}{r}30 \\
8\end{array}$ \\
\hline & & & 2B 4300 & $-\mathbf{M a}$ & ckys C. & reek $\mathbf{n}$ & ar Der & nnis, 'T & Tishoming & Sou & nty, $\mathbf{M}$ & liss. (d & Irainage & area, 66 & square & miles) & & & \\
\hline Tus $>$ & $\begin{array}{r}11-3-59 \\
5-30-60\end{array}$ & $\begin{array}{l}28.9 \\
35.4\end{array}$ & $\begin{array}{l}2.0 \\
3.6\end{array}$ & $\begin{array}{r}0.30 \\
.18\end{array}$ & $\begin{array}{l}2.9 \\
2.2\end{array}$ & $\begin{array}{l}0.9 \\
1.3\end{array}$ & $\begin{array}{l}1.2 \\
1.1\end{array}$ & $\begin{array}{r}1.0 \\
.8\end{array}$ & $\begin{array}{l}14 \\
13\end{array}$ & $\begin{array}{l}1.4 \\
2.0\end{array}$ & $\begin{array}{l}2.0 \\
1.8\end{array}$ & $\begin{array}{r}0.1 \\
.0\end{array}$ & $\begin{array}{r}0.6 \\
.5\end{array}$ & $\begin{array}{l}24 \\
20\end{array}$ & $\begin{array}{l}10 \\
11\end{array}$ & $\begin{array}{l}0 \\
0\end{array}$ & $\begin{array}{l}37 \\
29\end{array}$ & $\begin{array}{l}6.5 \\
6.5\end{array}$ & $\begin{array}{l}40 \\
25\end{array}$ \\
\hline & & & 2B445 & 0. $-\mathbf{L u}$ & bbub C & Creek $\mathrm{r}$ & ear $\mathrm{Ca}$ & arrollto & on, Picker & ns Cou & inty, A & la. (dra & ainage ar & rea, $116 \mathrm{~s}$ & square $\mathrm{r}$ & miles) & & & \\
\hline & $\begin{array}{r}11-4-59 \\
6-14-60\end{array}$ & $\begin{array}{l}35.0 \\
12.0\end{array}$ & $\begin{array}{l}5.5 \\
5.1\end{array}$ & $\begin{array}{r}0.18 \\
.50\end{array}$ & $\begin{array}{l}3.2 \\
3.4\end{array}$ & $\begin{array}{r}0.7 \\
.8\end{array}$ & $\begin{array}{l}1.8 \\
1.9\end{array}$ & $\begin{array}{r}1.3 \\
.8\end{array}$ & $\begin{array}{l}13 \\
12\end{array}$ & $\begin{array}{r}1.6 \\
.2\end{array}$ & $\begin{array}{l}3.5 \\
2.0\end{array}$ & $\begin{array}{r}0.0 \\
.1\end{array}$ & $\begin{array}{l}0.4 \\
2.4\end{array}$ & $\begin{array}{l}25 \\
23\end{array}$ & $\begin{array}{l}11 \\
12\end{array}$ & $\begin{array}{l}0 \\
2\end{array}$ & $\begin{array}{l}36 \\
35\end{array}$ & $\begin{array}{l}6.2 \\
6.4\end{array}$ & $\begin{array}{l}40 \\
45\end{array}$ \\
\hline & & & & 4659.- - & Big Cre & eek nes & I Wed & Igewor & th, Hale & Count & y, Ala. & (drain & tage ares &, $193 \mathrm{squ}$ & are $\mathrm{mi}$ & les) & & & \\
\hline Eutaw and McShan Formations & $\begin{array}{r}12-3-59 \\
6-13-60\end{array}$ & $\begin{array}{l}64.8 \\
34.0\end{array}$ & $\begin{array}{l}5.5 \\
7.5\end{array}$ & $\begin{array}{r}0.00 \\
.00\end{array}$ & ${ }_{21}^{9.2}$ & $\begin{array}{l}2.7 \\
5.2\end{array}$ & $\begin{array}{l}33 \\
79\end{array}$ & $\begin{array}{l}2.1 \\
3.5\end{array}$ & $\begin{array}{l}18 \\
26\end{array}$ & $\begin{array}{l}3.8 \\
2.4\end{array}$ & $\begin{array}{r}64 \\
154\end{array}$ & $\begin{array}{r}0.1 \\
.2\end{array}$ & $\begin{array}{l}0.1 \\
2.6\end{array}$ & $\begin{array}{l}129 \\
288\end{array}$ & $\begin{array}{l}34 \\
74\end{array}$ & $\begin{array}{l}19 \\
52\end{array}$ & $\begin{array}{l}254 \\
615\end{array}$ & $\begin{array}{l}6.8 \\
7.0\end{array}$ & $\begin{array}{l}8 \\
6\end{array}$ \\
\hline & & 3B5927.- & -Yellor & w Cree & k Drai & nage $C$ & anal at & Burns & sville, Tis & homin & ggo Cox & inty, $M$ & Miss. (dr & ainage at & rea, 46 . & 3 squar & ire mile & & \\
\hline Eutaw Fo & $\begin{array}{r}11-3-59 \\
5-30-60\end{array}$ & $\begin{array}{l}1.13 \\
3.74\end{array}$ & $\begin{array}{l}9.3 \\
1.8\end{array}$ & $\begin{array}{r}0.61 \\
.00\end{array}$ & $\begin{array}{l}3.9 \\
3.0\end{array}$ & $\begin{array}{l}2.6 \\
1.2\end{array}$ & $\begin{array}{l}2.0 \\
2.0\end{array}$ & $\begin{array}{l}2.3 \\
1.1\end{array}$ & $\begin{array}{l}25 \\
16\end{array}$ & $\begin{array}{l}3.8 \\
3.6\end{array}$ & $\begin{array}{l}2.2 \\
2.0\end{array}$ & $\begin{array}{r}0.1 \\
.0\end{array}$ & $\begin{array}{r}0.5 \\
.5\end{array}$ & $\begin{array}{l}39 \\
23\end{array}$ & $\begin{array}{l}20 \\
12\end{array}$ & $\begin{array}{l}0 \\
0\end{array}$ & $\begin{array}{l}55 \\
40\end{array}$ & $\begin{array}{l}6.8 \\
6.6\end{array}$ & $\begin{array}{l}35 \\
15\end{array}$ \\
\hline & & & B4299.- & -Big B & rown C & Treek n & ear Bo & onevill & le, Prenti & iss Cou & inty, $\mathrm{N}$ & Liss. (d & drainage & area, 30 . & .7 squa & re mile & & & \\
\hline & $\begin{array}{r}11-3-59 \\
5-30-60\end{array}$ & $\begin{array}{l}1.13 \\
4.41\end{array}$ & $\begin{array}{l}9.7 \\
3.2\end{array}$ & $\begin{array}{r}0.11 \\
.21\end{array}$ & $\begin{array}{l}23 \\
11\end{array}$ & $\begin{array}{l}4.0 \\
2.6\end{array}$ & $\begin{array}{l}2.7 \\
1.6\end{array}$ & $\begin{array}{l}3.2 \\
1.2\end{array}$ & $\begin{array}{l}77 \\
38\end{array}$ & $\begin{array}{c}17 \\
9.8\end{array}$ & $\begin{array}{l}3.0 \\
2.2\end{array}$ & $\begin{array}{r}0.1 \\
.0\end{array}$ & $\begin{array}{r}0.6 \\
.3\end{array}$ & $\begin{array}{r}101 \\
51\end{array}$ & $\begin{array}{l}74 \\
38\end{array}$ & $\begin{array}{r}11 \\
7\end{array}$ & $\begin{array}{r}162 \\
85\end{array}$ & $\begin{array}{l}7.1 \\
7.2\end{array}$ & $\begin{array}{l}10 \\
25\end{array}$ \\
\hline & & & 7-02 & 292.5. - & Hatchi & ie Rive & near & Ripley & , Tippah & Count & y, Mis & . (drai & inage ar & $\mathrm{ea}, 40 \mathrm{squ}$ & uare $\mathrm{m}$ & iles) & & & \\
\hline Ripley Formation & $\begin{array}{r}11-3-59 \\
5-30-60\end{array}$ & $\begin{array}{c}9.41 \\
10.8\end{array}$ & $\begin{array}{l}6.4 \\
1.8\end{array}$ & $\begin{array}{r}0.21 \\
.00\end{array}$ & $\begin{array}{l}1.9 \\
2.9\end{array}$ & $\begin{array}{l}1.8 \\
1.0\end{array}$ & $\begin{array}{l}1.2 \\
1.1\end{array}$ & $\begin{array}{r}1.0 \\
.6\end{array}$ & $\begin{array}{l}16 \\
14\end{array}$ & $\begin{array}{r}0.0 \\
.8\end{array}$ & $\begin{array}{l}2.2 \\
2.0\end{array}$ & $\begin{array}{r}0.1 \\
.0\end{array}$ & $\begin{array}{r}0.5 \\
.5\end{array}$ & $\begin{array}{l}23 \\
18\end{array}$ & $\begin{array}{l}12 \\
11\end{array}$ & $\begin{array}{l}0 \\
0\end{array}$ & $\begin{array}{l}35 \\
30\end{array}$ & $\begin{array}{l}6.9 \\
6.5\end{array}$ & $\begin{array}{l}25 \\
25\end{array}$ \\
\hline
\end{tabular}


TABLE 9.-Chemical analyses of low-flow surface waters in the Mississippi embayment in Mississippi and Alabama-Continued

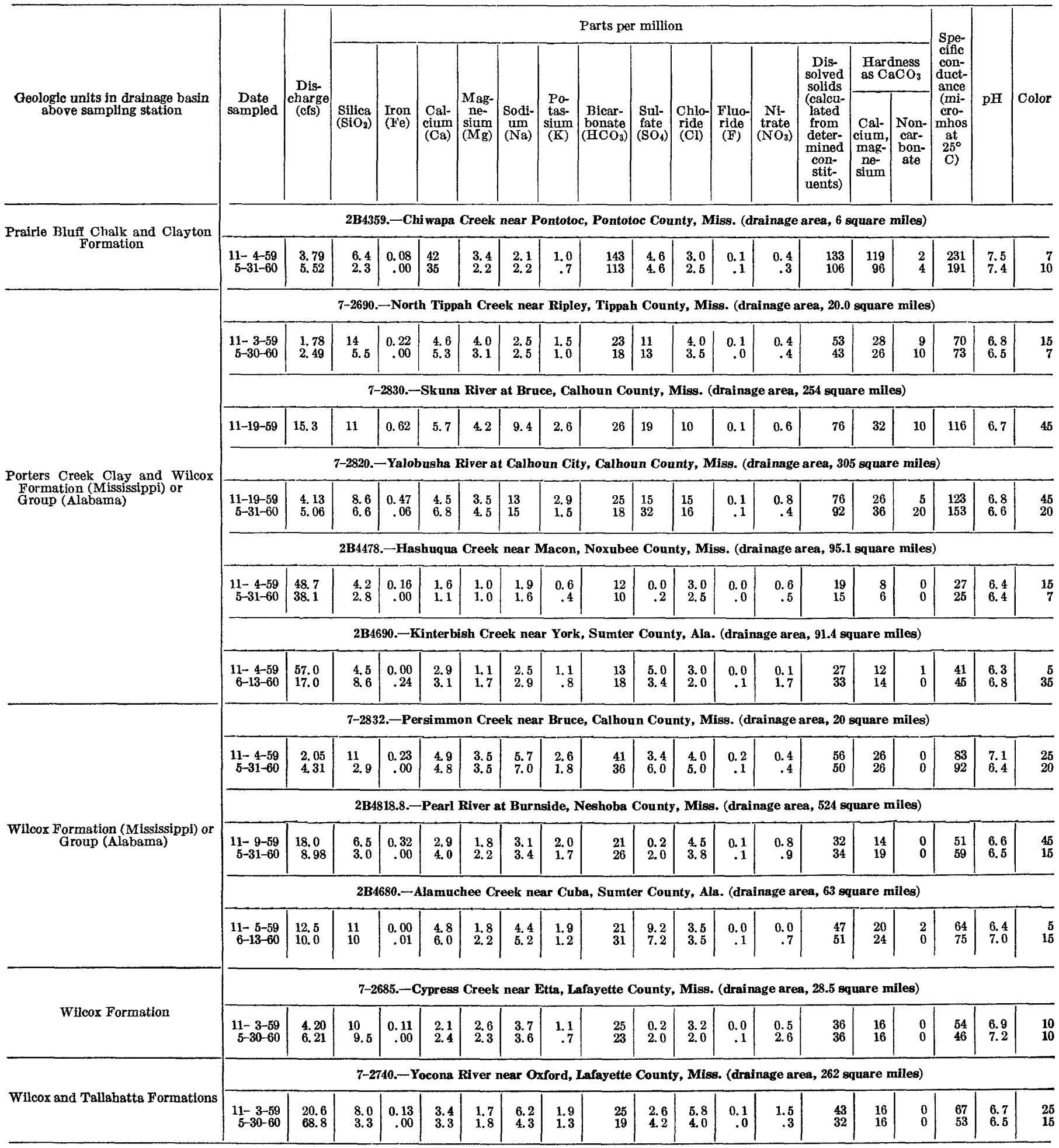


TABLE 9.-Chemical analyses of low-flow surface waters in the Mississippi embayment in Mississippi and Alabama-Continued

\begin{tabular}{|c|c|c|c|c|c|c|c|c|c|c|c|c|c|c|c|c|c|c|c|}
\hline \multirow{3}{*}{$\begin{array}{l}\text { Geologic units in drainage basin } \\
\text { above sampling station }\end{array}$} & \multirow{3}{*}{$\begin{array}{c}\text { Date } \\
\text { sampled }\end{array}$} & \multirow{3}{*}{$\begin{array}{c}\text { Dis- } \\
\text { charge } \\
\text { (efs) }\end{array}$} & \multicolumn{14}{|c|}{ Parts per million } & \multirow{3}{*}{$\begin{array}{l}\text { Spe- } \\
\text { cific } \\
\text { con- } \\
\text { duct- } \\
\text { ance } \\
\text { (mi- } \\
\text { cro- } \\
\text { mhos } \\
\text { at } \\
25^{\circ} \\
\text { C) }\end{array}$} & \multirow{3}{*}{$\mathrm{pH}$} & \multirow{3}{*}{ Color } \\
\hline & & & \multirow{2}{*}{$\begin{array}{l}\text { Silica } \\
\left(\mathrm{SiO}_{2}\right)\end{array}$} & \multirow[b]{2}{*}{$\underset{(\mathrm{Fe})}{\text { Iron }}$} & \multirow[b]{2}{*}{$\begin{array}{l}\text { Cal- } \\
\text { cium } \\
(\mathrm{Ca})\end{array}$} & \multirow{2}{*}{$\begin{array}{l}\text { Mag- } \\
\text { ne- } \\
\text { sium } \\
(\mathrm{Mg})\end{array}$} & \multirow{2}{*}{$\underset{(\mathrm{Na})}{\substack{\text { Sodi- } \\
\operatorname{um}^{-}}}$} & \multirow{2}{*}{$\begin{array}{c}\text { Po- } \\
\text { tas- } \\
\text { sium } \\
(\mathrm{K})\end{array}$} & \multirow[b]{2}{*}{$\begin{array}{r}\text { Bicar- } \\
\text { bonate } \\
\left(\mathrm{HCO}_{3}\right)\end{array}$} & \multirow[b]{2}{*}{$\begin{array}{l}\text { Sul- } \\
\text { fate } \\
\left(\mathrm{SO}_{4}\right)\end{array}$} & \multirow[b]{2}{*}{$\begin{array}{l}\text { Chlo- } \\
\text { ride } \\
\text { (Cl) }\end{array}$} & \multirow[b]{2}{*}{$\begin{array}{l}\text { Fluo- } \\
\text { ride } \\
(\mathrm{F})\end{array}$} & \multirow[b]{2}{*}{$\begin{array}{l}\text { Ni- } \\
\text { trate } \\
\left(\mathrm{NO}_{3}\right)\end{array}$} & \multirow{2}{*}{$\begin{array}{c}\text { Dis- } \\
\text { solved } \\
\text { solids } \\
\text { (calcu- } \\
\text { lated } \\
\text { from } \\
\text { deter- } \\
\text { mined } \\
\text { con- } \\
\text { stit- } \\
\text { uents) }\end{array}$} & \multicolumn{2}{|c|}{$\begin{array}{l}\text { Hardness } \\
\text { as } \mathrm{CaCO}_{3}\end{array}$} & & & \\
\hline & & & & & & & & & & & & & & & $\begin{array}{l}\text { Cal- } \\
\text { cium, } \\
\text { mag- } \\
\text { ne- } \\
\text { sium }\end{array}$ & $\begin{array}{l}\text { Non- } \\
\text { car- } \\
\text { bon- } \\
\text { ate }\end{array}$ & & & \\
\hline \multirow{4}{*}{ Tallahatta Formation } & \multicolumn{19}{|c|}{ 7-0303.9.-Grays Creek near Michigan City, Benton County, Miss. (drainage area, 30 square miles) } \\
\hline & $\begin{array}{r}11-3-59 \\
5-30-60\end{array}$ & $\begin{array}{l}6.64 \\
7.68\end{array}$ & $\begin{array}{l}7.5 \\
3.6\end{array}$ & $\begin{array}{r}0.15 \\
.00\end{array}$ & $\begin{array}{l}1.7 \\
1.5\end{array}$ & $\begin{array}{l}1.4 \\
1.1\end{array}$ & $\begin{array}{l}2.2 \\
2.0\end{array}$ & $\begin{array}{r}0.8 \\
.6\end{array}$ & $\begin{array}{l}17 \\
15\end{array}$ & $\begin{array}{r}0.0 \\
.0\end{array}$ & $\begin{array}{l}2.0 \\
1.5\end{array}$ & $\begin{array}{r}0.0 \\
.0\end{array}$ & $\begin{array}{r}0.8 \\
.6\end{array}$ & $\begin{array}{l}25 \\
18\end{array}$ & $\begin{array}{r}10 \\
8\end{array}$ & $\stackrel{0}{0}$ & $\begin{array}{l}38 \\
27\end{array}$ & $\begin{array}{l}6.6 \\
6.6\end{array}$ & $\begin{array}{r}5 \\
10\end{array}$ \\
\hline & \multicolumn{19}{|c|}{ 7-2708.-Hurricane Creek near Oxford, Lafayette County, Miss. (drainage area, 9 square miles) } \\
\hline & $\begin{array}{r}11-3-59 \\
5-30-60\end{array}$ & $\begin{array}{l}9.38 \\
11.7\end{array}$ & $\begin{array}{l}7.0 \\
2.8\end{array}$ & $\begin{array}{r}0.36 \\
.00\end{array}$ & $\begin{array}{l}1.2 \\
1.1\end{array}$ & $\begin{array}{r}1.3 \\
.8\end{array}$ & $\begin{array}{l}1.9 \\
1.6\end{array}$ & $\begin{array}{r}0.6 \\
.2\end{array}$ & $\begin{array}{l}15 \\
11\end{array}$ & $\begin{array}{r}0.2 \\
.0\end{array}$ & $\begin{array}{l}2.0 \\
1.5\end{array}$ & $\begin{array}{r}0.0 \\
.0\end{array}$ & $\begin{array}{r}0.4 \\
.3\end{array}$ & $\begin{array}{l}22 \\
14\end{array}$ & $\begin{array}{l}8 \\
6\end{array}$ & $\begin{array}{l}0 \\
0\end{array}$ & $\begin{array}{l}26 \\
22\end{array}$ & $\begin{array}{l}6.6 \\
6.8\end{array}$ & $\begin{array}{r}9 \\
10\end{array}$ \\
\hline \multirow{2}{*}{$\begin{array}{c}\text { Tallahatta Formation and Sparta } \\
\text { Sand }\end{array}$} & \multicolumn{19}{|c|}{ 7-2840.-Cypress Creek near Coffeeville, Yalobusha County, Miss. (drainage area, 22.3 square miles) } \\
\hline & $\begin{array}{r}11-20-59 \\
5-31-60\end{array}$ & $\begin{array}{l}3.91 \\
2.57\end{array}$ & $\begin{array}{l}9.8 \\
6.5\end{array}$ & $\begin{array}{r}0.34 \\
.00\end{array}$ & $\begin{array}{l}2.7 \\
2.7\end{array}$ & $\begin{array}{l}1.8 \\
2.4\end{array}$ & $\begin{array}{l}4.7 \\
4.8\end{array}$ & $\begin{array}{r}1.1 \\
.7\end{array}$ & $\begin{array}{l}21 \\
24\end{array}$ & $\begin{array}{l}5.2 \\
2.8\end{array}$ & $\begin{array}{l}4.0 \\
\text { 3. } 5\end{array}$ & $\begin{array}{r}0.1 \\
.0\end{array}$ & $\begin{array}{r}0.5 \\
.4\end{array}$ & $\begin{array}{l}40 \\
36\end{array}$ & $\begin{array}{l}14 \\
16\end{array}$ & $\begin{array}{l}0 \\
0\end{array}$ & $\begin{array}{l}55 \\
55\end{array}$ & $\begin{array}{l}6.6 \\
6.4\end{array}$ & $\begin{array}{l}25 \\
10\end{array}$ \\
\hline \multirow[b]{2}{*}{$\begin{array}{c}\text { Tallahatta Formation, Winona } \\
\text { Sand, and Sparta Sand }\end{array}$} & \multicolumn{19}{|c|}{ 7-2892.7. - Hays Creek near Vaiden, Carroll County, Miss. (drainage area, 80 square miles) } \\
\hline & $\begin{array}{l}11-13-59 \\
10-25-60\end{array}$ & $\begin{array}{l}5.54 \\
1.22\end{array}$ & ${ }^{10} 7.7$ & $\begin{array}{r}0.32 \\
.00\end{array}$ & ${ }_{11}^{8.6}$ & $\begin{array}{l}5.3 \\
5.9\end{array}$ & $\begin{array}{l}20 \\
26\end{array}$ & $\begin{array}{l}5.0 \\
4.5\end{array}$ & $\begin{array}{l}45 \\
64\end{array}$ & $\begin{array}{l}30 \\
29\end{array}$ & $\begin{array}{l}16 \\
20\end{array}$ & $\begin{array}{r}0.2 \\
.4\end{array}$ & $\begin{array}{l}2.6 \\
6.0\end{array}$ & $\begin{array}{l}120 \\
142\end{array}$ & $\begin{array}{l}44 \\
52\end{array}$ & $\begin{array}{l}6 \\
0\end{array}$ & $\begin{array}{l}197 \\
235\end{array}$ & $\begin{array}{l}6.8 \\
6.8\end{array}$ & $\begin{array}{r}25 \\
5\end{array}$ \\
\hline & \multicolumn{19}{|c|}{ 7-2805.-North Fork Tillatoba Creek near Charleston, Tallahatchie County, Miss. (drainage area, 43.7 square miles) } \\
\hline Sparta Sand & $\begin{array}{r}11-20-59 \\
5-31-60\end{array}$ & $\begin{array}{l}5.20 \\
5.25\end{array}$ & $\begin{array}{l}12 \\
11\end{array}$ & $\begin{array}{r}0.57 \\
.01\end{array}$ & $\begin{array}{l}5.5 \\
5.4\end{array}$ & $\begin{array}{l}3.3 \\
2.9\end{array}$ & $\begin{array}{l}7.0 \\
7.8\end{array}$ & $\begin{array}{l}2.5 \\
1.2\end{array}$ & $\begin{array}{l}44 \\
42\end{array}$ & $\begin{array}{l}0.6 \\
3.2\end{array}$ & $\begin{array}{l}5.2 \\
5.0\end{array}$ & $\begin{array}{r}0.2 \\
.1\end{array}$ & $\begin{array}{r}0.6 \\
.5\end{array}$ & $\begin{array}{l}60 \\
58\end{array}$ & $\begin{array}{l}27 \\
26\end{array}$ & $\begin{array}{l}0 \\
0\end{array}$ & $\begin{array}{l}90 \\
91\end{array}$ & $\begin{array}{l}6.9 \\
7.2\end{array}$ & $\begin{array}{r}50 \\
6\end{array}$ \\
\hline & \multicolumn{19}{|c|}{ 7-2895.3.-Doaks Creek near Canton, Madison County, Miss. (drainage area, 161 square miles) } \\
\hline Cockfield Formation & $\begin{array}{r}11-13-59 \\
6-1-60\end{array}$ & $\begin{array}{l}22.1 \\
22.1\end{array}$ & $\begin{array}{l}9.7 \\
3.5\end{array}$ & $\begin{array}{l}1.4 \\
.00\end{array}$ & $\begin{array}{l}5.1 \\
6.5\end{array}$ & $\begin{array}{l}2.7 \\
2.9\end{array}$ & $\begin{array}{l}6.8 \\
8.0\end{array}$ & $\begin{array}{l}1.7 \\
1.7\end{array}$ & $\begin{array}{l}25 \\
29\end{array}$ & ${ }_{12}^{9.6}$ & $\begin{array}{l}8.0 \\
8.0\end{array}$ & $\begin{array}{r}0.1 \\
.0\end{array}$ & $\begin{array}{r}0.6 \\
.5\end{array}$ & $\begin{array}{l}58 \\
57\end{array}$ & $\begin{array}{l}24 \\
28\end{array}$ & $\begin{array}{l}3 \\
4\end{array}$ & $\begin{array}{r}87 \\
102\end{array}$ & $\begin{array}{l}6.8 \\
6.9\end{array}$ & $\begin{array}{l}35 \\
15\end{array}$ \\
\hline \multirow{2}{*}{$\begin{array}{l}\text { Quaternary alluvium (Missis- } \\
\text { sippi River) }\end{array}$} & \multicolumn{19}{|c|}{ 7-2885.7.-Quiver River near Doddsville, Leflore County, Miss. (drainage area, 292 square miles) } \\
\hline & $\begin{array}{l}11-20-59 \\
10-25-60\end{array}$ & $\begin{array}{l}18.6 \\
27.6\end{array}$ & $\begin{array}{l}6.0 \\
4.4\end{array}$ & $\begin{array}{r}0.00 \\
.00\end{array}$ & $\begin{array}{l}19 \\
17\end{array}$ & $\begin{array}{l}7.9 \\
5.4\end{array}$ & $\begin{array}{l}6.8 \\
5.1\end{array}$ & $\begin{array}{l}9.1 \\
5.9\end{array}$ & $\begin{array}{l}94 \\
84\end{array}$ & $\stackrel{13}{9.0}$ & $\begin{array}{l}\text { 8. } 0 \\
\text { 3. } 2\end{array}$ & $\begin{array}{r}0.2 \\
.3\end{array}$ & $\begin{array}{l}0.7 \\
1.1\end{array}$ & $\begin{array}{r}117 \\
92\end{array}$ & $\begin{array}{l}80 \\
64\end{array}$ & $\begin{array}{l}3 \\
0\end{array}$ & $\begin{array}{l}199 \\
165\end{array}$ & $\begin{array}{l}7.3 \\
6.9\end{array}$ & $\begin{array}{l}30 \\
17\end{array}$ \\
\hline
\end{tabular}

TABLE 10.-Source and significance of dissolved mineral constituents and properties of water

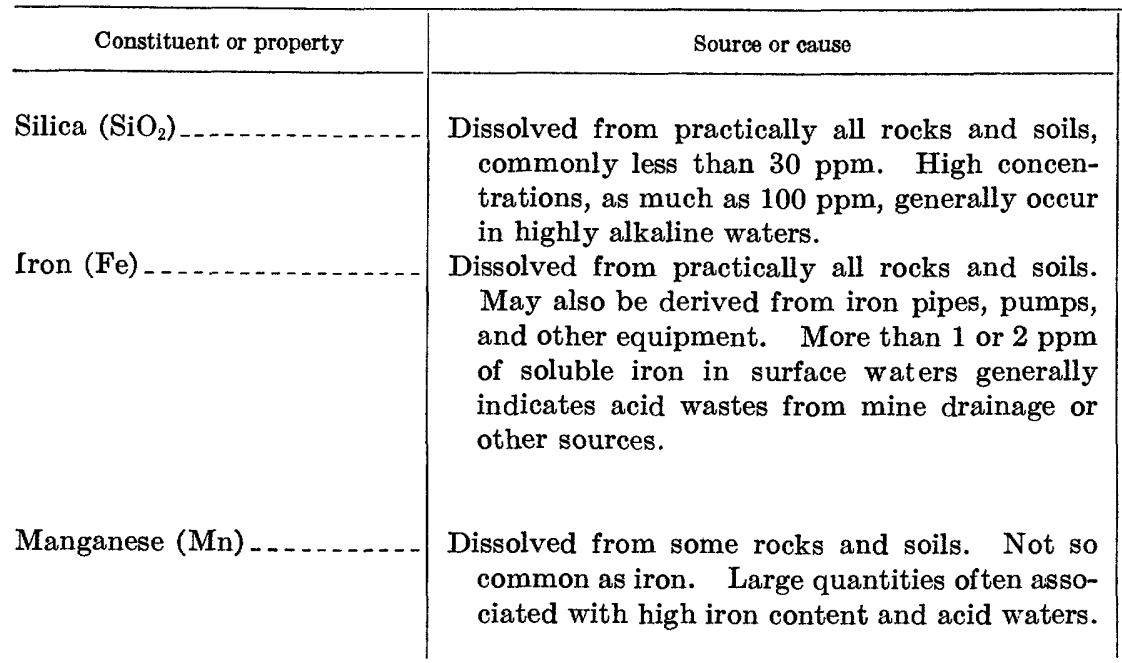

Significance
Forms hard scale in pipes and boilers. Carried
over in steam of high-pressure boilers to form
deposits on blades of turbines. Inhibits dete-
rioration of zeolite-type water softeners.
More than about 0.3 ppm stains laundry and
utensils reddish brown. Objectionable for food
processing, textile processing, beverages, ice
manufacture, brewing, and other processes.
UsPHS (1962) 1 drinking-water standards state
that iron should not exceed 0.3 ppm. Larger
quantities cause unpleasant taste and favor
growth of iron bacteria.
Same objectionable features as iron. Causes
dark brown or black stain. USPHS (1962)
drinking-water standards state that manganese
should not exceed 0.05 ppm.


TABLE 10.-Source and significance of dissolved mineral constituents and properties of water-Continued

Constituent or property
Calcium $(\mathrm{Ca})$ and magne-
sium $(\mathrm{Mg})$.

Sodium $(\mathrm{Na})$ and potassium $(\mathrm{K})$. Bicarbonate $\left(\mathrm{HCO}_{3}\right)$ and
carbonate $\left(\mathrm{CO}_{3}\right)$

Sulfate $\left(\mathrm{SO}_{4}\right)$

Chloride (Cl)

Fluoride (F)

Nitrate $\left(\mathrm{NO}_{3}\right)$
Dissolved from practically all rocks and soils, but especially from limestone, dolomite, and gypsum. Calcium and magnesium are found in large quantities in some brines. Magnesium is present in large quantities in sea water.

Dissolved from practically all rocks and soils. Found also in ancient brines, sea water, industrial brines, and sewage.

Action of carbon dioxide in water on carbonate rocks such as limestone and dolomite.

Dissolved from rocks and soils containing gypsum, iron sulfides, and other sulfur compounds. Commonly present in mine waters and some industrial wastes.

Dissolved from rocks and soils. Present in sewage and found in large amounts in ancient brines, sea water, and industrial wastes.

Dissolved in small to minute quantities from most rocks and soils. Added to many waters by fluoridation of municipal supplies.

Decaying organic matter, legume plants, sewage, nitrate fertilizers, and nitrates in soils.
Cause most of the hardness and scale-forming properties of water; soap consuming (see Hardness). Waters low in calcium and magnesium desired in electroplating, tanning, and dyeing and in textile manufacturing.

Large amounts, in combination with chloride, give a salty taste. Moderate quantities have little effect on the usefulness of water for most purposes. Sodium salts may cause foaming in steam boilers, and a high sodium content may limit the use of water for irrigation.

Bicarbonate and carbonate produce alkalinity. Bicarbonates of calcium and magnesium decompose in steam boilers and hot-water facilities to form scale and release corrosive carbon dioxide gas. In combination with calcium and magnesium they cause carbonate hardness.

Sulfate in water containing calcium forms hard scale in steam boilers. In large amounts, sulfate in combination with other ions gives a bitter taste to water. Some calcium sulfate is considered beneficial in the brewing process. USPHS (1962) drinking-water standards recommend that the sulfate content should not exceed 250 ppm.

In large amounts in combination with sodium gives salty taste to water. In large quantities increases the corrosiveness of water. USPHS (1962) drinking-water standards recommend that the chloride content not exceed $250 \mathrm{ppm}$.

Fluoride in drinking water reduces the incidence of tooth decay when the water is consumed during the period of enamel calcification. However, it may cause mottling of the teeth depending on the concentration of fluoride, the age of the child, the amount of water consumed, and the susceptibility of the individual. The maximum concentration of fluoride recommended by the USPHS (1962) varies with the annual average of maximum daily air temperatures and ranges downward from $1.7 \mathrm{ppm}$ for an average maximum daily temperature of $50.0^{\circ} \mathrm{F}$ to $0.8 \mathrm{ppm}$ for an average maximum daily temperature of $90.5^{\circ} \mathrm{F}$. Optimum concentrations for these ranges are from 1.2 to $0.7 \mathrm{ppm}$.

Concentration much greater than the local average may suggest pollution. USPHS (1962) drinking-water standards suggest a limit of $\mathbf{4 5}$ ppm. Waters of high nitrate content have been reported to be the cause of methemoglobinemia (an often fatal disease in infants) and therefore should not be used in infant feeding. Nirate has been shown to be helpful in reducing the intercrystalline cracking of boiler steel. It encourages the growth of algae and other organisms which may cause odor problems in water supplies. 
TABLE 10.-Source and significance of dissolved mineral constituents and properties of water-Continued

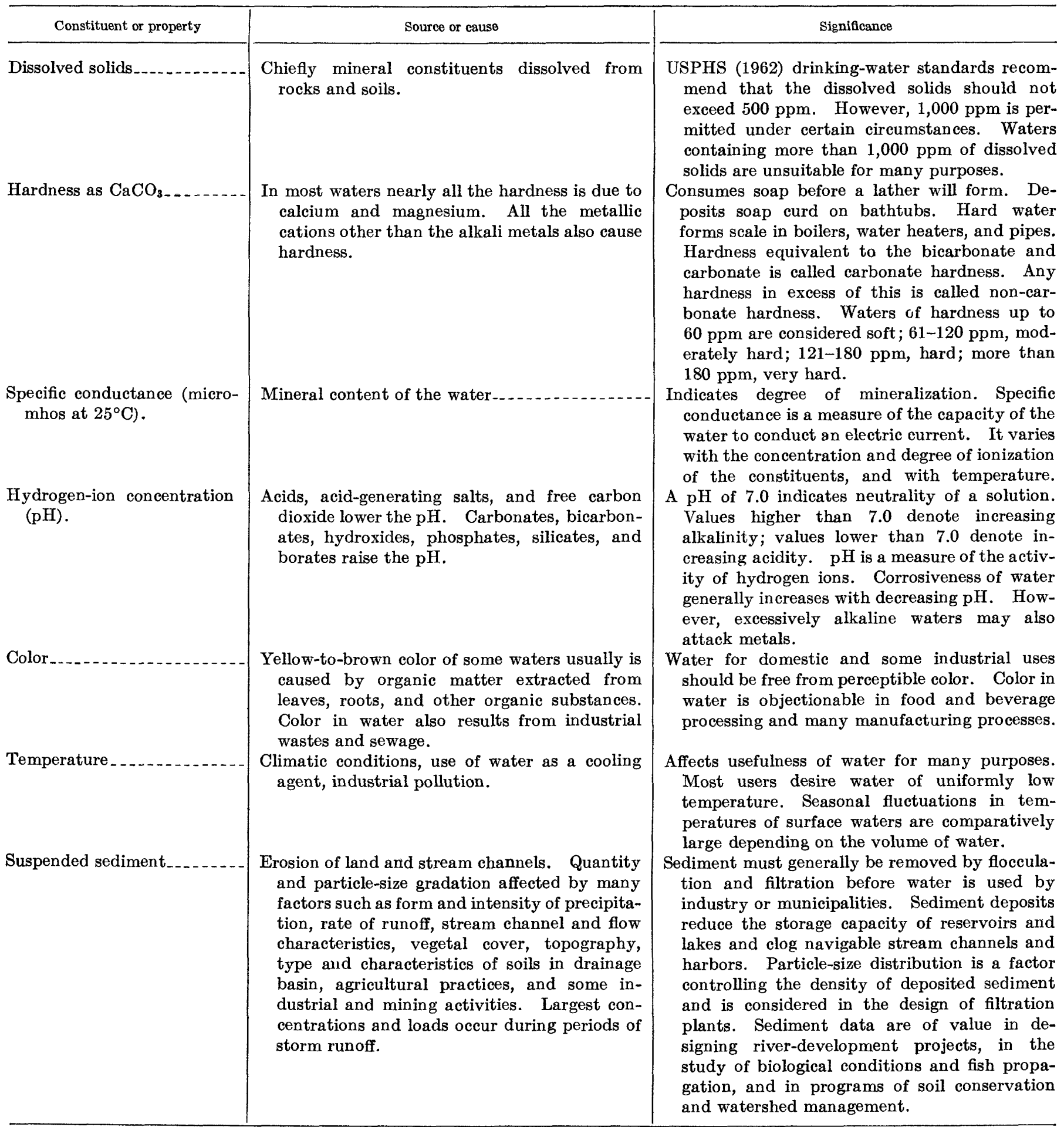

1 "Public Health Service Drinking Water Standards," revised 1962, apply to drinking water and water-supply systems used by carriers and others subject to Federal quarantine regulations.

chemical composition to water from streams draining only Wilcox deposits; the three samples contained greater concentrations of sodium, sulfate, and chloride. Chiwapa Creek drains the Clayton Formation and
Prairie Bluff Chalk. Water sampled from this creek has a dissolved-solids content of about $125 \mathrm{ppm}$, which is largely calcium bicarbonate.

Water from streams that derive their base flow from 
the Tuscaloosa Group and from the MeShan and Eutaw Formations generally is the least mineralized of all the low-flow water sampled for the study. No individual chemical constituent attains a concentration of more than a few parts per million, and the dissolvedsolids content is generally less than $30 \mathrm{ppm}$. An exception to this is the water from Big Creek near Wedgeworth, Ala. The high mineralization of this water apparently is caused by the discharge of mineralized water from a flowing well into the creek upstream from the sampling site.

An attempt was made to identify low-flow water as coming from a particular geologic unit on the basis of the chemical analysis alone, but differences in the chemical quality were too small to serve as a basis for definite identification. Water from the Quaternary alluvium was distinguishable from water from the Tuscaloosa Group on the basis of chemical characteristics, but water from the Tuscaloosa Group, the McShan and Eutaw Formations, and the Tallahatta Formation could not be identified separately because the range of mineral content among the various samples from the same unit was frequently greater than the range in some of the samples from different geologic units.

It is unlikely that there should be an analysis even approximately "typical" of any geologic unit because of the differences in the physical makeup of the unit from place to place. Density, porosity, grain size, and solubility of the stratum constituents play a part in determining the ultimate mineral content of the water draining from the unit. Therefore, the geology of the drainage basins cannot be determined with any assurance from the analyses of the low-flow waters, but the approximate quality of a low-flow water can be estimated with considerable accuracy if the geologic unit contributing the low flow is known.

Chemical composition of surface water at a particular location during low-flow periods commonly remains fairly constant for periods of months. On the other hand, the composition of streams draining the same geologic unit may vary considerably at different locations even during the same time period. Although the quality of a water draining from a unit is directly related to the soluble constituents of the material forming the unit, local variations in the composition of the stratum and the type of flow through the stratum tend to cause variations in the quality of the water at low flow at different locations in the same unit.

\section{CONCLUSIONS AND RECOMMENDATIONS}

1. The low-flow characteristics of streams in the Mississippi embayment in Mississippi and Alabama are useful in the solution of water problems in the area. The need for further development of water resources, particularly for consumptive uses, was accentuated by the drought of the 1950's and has increased rapidly in recent years. In some areas the entire low flow of the streams has been used during dry seasons, and in other areas the use of surface water has greatly altered the low-flow characteristics of the streams. As industry and agriculture continue to expand, the critical areas may be expected to increase in number and become more widespread. Planned development of the water resources and effective water management, guided by the results of this study and by future investigations, offer a basis for meeting the future needs for water in the area.

2. Comparison of the low-flow characteristics of the streams has been made on the basis of unit runoff per square mile. However, because of the wide variations in the yield of the streams, and even of the same stream, interpolation of low-flow data presented in this report should not be made at ungaged sites on basis of drainage area without the aid of low-flow discharge measurements at the sites and without a knowledge of the geology, physiography, and other factors affecting the low flow.

3. The high indices of base flow of Luxapalila Creek upstream from the Alabama-Mississippi line, in the reach that was canalized in 1922, suggest that the deeper channel after canalization intercepted more ground water and that the resulting lowering of the groundwater table in the bordering swamps reduced the evapotranspiration losses, thus increasing the low flow in this reach of the stream.

4. In the Fall Line Hills, the combination of widespread deposits of sand and gravel that have high yields and streams that are incised to sufficeint depth to intercept the ground water constitutes a hydrogeologic arrangement specially favorable to sustaining base flow. The terrace deposits along the Black Warrior River are highly permeable and contribute to the high base flow of streams in that area.

In the southern part of the Flatwoods and in the North Central Plateau, streams in the Tuscahoma Sand, the Nanafalia Formation, and locally the Naheola Formation show good yields.

In the extreme northern part of the North Central Plateau, some of the tributaries to the Tallahatchie River, which receive their base flow from the Tallahatta Formation, show indices exceeding 1 cfs per sq mi. These indices are the highest of any in the study area.

The wide differences in the low-flow indices of streams in these areas may be attributed in part to the depth to which the streams are incised, to the porosity and permeability of the aquifers in the immediate area, and to the characteristics of the alluvial sediments in the stream valleys. Some of the lower yielding streams in 
these areas suggest possible locations for investigating ways and means of increasing the low flow.

5. In the Yazoo Delta, complete analysis of low-flow characteristics is almost impossible because of the poorly defined drainage areas and the continuing manmade changes and additions to the drainage systems, which were begun in the early 1800's and which continually modify the low-flow characteristics of the streams. In the Yazoo Delta, withdrawals of water from the streams and wells for irrigation since 1951 have had a much greater effect upon the low flow than manmade changes have had in any other part of the study area. The following are the only interpretations that can be made from the data available:

(a) Low-flow indices for the Sunflower and Hushpuckena Rivers and for Bogue Phalia show reductions in indices of from 27 to 36 percent resulting from withdrawals for irrigation since 1951.

(b) The indices of low flow in the Sunflower River increase in a downstream direction because of the change in composition of the alluvium, the generally southward movement of the ground water, and the increase in channel width and the accompanying increase in the area of waterbearing deposits exposed in the channel.

(c) For the period June-September during most years, the natural low flow of the main stems of streams in the Yazoo River basin below the four floodcontrol reservoirs has increased owing to operation of the reservoirs.

6. The median annual 7-day low flow serving as an index, areal draft-storage relations for 10-year and 20-year recurrence intervals provide a convenient means for estimating the storage required to maintain a given minimum flow. The relations are valid for median annual 7-day low flows of as much as $0.40 \mathrm{cfs}$ per sq mi and for storages of 0-90 acre-feet per square mile. Application of these relations is not recommended for intermittent streams or for daily-record gaging sites.

7. Data are needed to define additional causative phases of the hydrologic systems and to forecast the effect that future changes in the stream systems may have upon the low-flow regimen of the streams. These phases would include the effect of floods upon the ground-water table adjacent to the streams, the effect of swamp environment on the yield from or recharge to the aquifers, the effect of deepening or widening of stream channels upon the regimen of low flow of the streams and upon the ground-water table adjacent to the streams, the interrelations between the ground-water recession and the low-flow recession of streams, and the effect of impoundment of waters in ponds and reservoirs on the low flow of the streams. The results of the study indicate that increases or decreases in low flow result from manmade changes. Further studies are needed to quantitatively evaluate the effects that future manmade changes may have on the hydrologic systems in the area.

8. During low-flow periods, similarities in chemical characteristics of surface waters maintained by flow from certain geologic units are evident, but relations are not sufficiently well defined to permit identifying a geologic unit by the chemical analysis of low-flow water that drains from it.

Analysis of waters discharging from certain widely separated geologic units show similar chemical characteristics. On the basis of these results, it can be reasoned that water having these chemical characteristics most likely did not come from other geologic units. On the other hand, the chemical quality of a stream whose flow is maintained by discharge from a particular geologic unit can generally be estimated with reasonable accuracy. In making such estimates, allowance must be made for frequent anomalies and departure from the expected that may be caused by unknown local conditions in the geologic unit.

\section{SELECTED REFERENCES}

Adams, G. I., Butts, Charles, Stevenson, L. W., and Cooke, Wythe, 1926, Geology of Alabama: Alabama Geol. Survey Special Rept. 14, 312 p.

Anderson, I. E., and others, 1956, Louisiana's Waters: U.S. Geol. Survey and Louisiana Dept. Public Works open-file report, $81 \mathrm{p}$.

Cushing, E. M., Boswell, E. H., and Hosman, R. L., 1964, General geology of the Mississippi embayment: U.S. Geol. Survey Prof. Paper 448-B, p. 1-28.

Fenneman, N. M., 1938, Physiography of Eastern United States: New York and London, McGraw-Hill Book Co., 714 p.

Goines, W. H., 1955, Flood of May 27-28, 1954, in Parola and Lafayette Counties, Mississippi: U.S. Geol. Survey openfile report, $13 \mathrm{p}$.

Harbeck, G. E., Golden, H. G., and Harvey, E. J., 1961, Effect of irrigation withdrawals on stage of Lake Washington, Mississippi: U.S. Geol. Survey Water-Supply Paper 1460-I, p. 359-388.

Hardison, C. H., and Martin, R. O. R., 1963, Low-flow frequency curves for selected long-term stream-gaging stations in Eastern United States: U.S. Geol. Survey Water-Supply Paper 1669-G, $30 \mathrm{p}$.

Illinois State Water Survey Division [no date], Influence of flood of 1943 on ground water supplies at Peoria, East St. Louis, and Cairo, in Floods of May 1943 in Illinois: I1linois Dept. Public Works and Buildings, Division of Waterways, p. 147-151.

Langbein, W. B., and Iseri, K. T., 1960, General introduction and hydrologic definitions: U.S. Geol. Survey WaterSupply Paper 1541-A, 29 p. 
Peirce, L. B., 1954, Floods in Alabama, magnitude and frequency: U.S. Geol. Survey Circ. 342, 105 p.

1957, Flow-duration data for Alabama streams: U.S. Geol. Survey, in cooperation with Alabama Geol. Survey and U.S. Army Corps of Engineers, open-file report, 283 p. - 1959, Low-flow and flow-duration data for Alabama streams: U.S. Geol. Survey, in cooperation with Alabama Water Improvement Commission, open-file report, 168 p.

Peirce, L. B., and Guerin, J. W., 1959, Surface-water resources and hydrology of west-central Alabama: Alabama Geol. Survey Special Rept. 24, 236 p.

Robinson, W. H., and Skelton, John, 1960, Minimum flows at stream-gaging stations in Mississippi: Mississippi Board Water Comm. Bull. 60-1, 91 p.

Searcy, J. K., 1959, Flow-duration curves: U.S. Geol. Survey Water-Supply Paper 1542-A, 33 p.

1960, Graphical correlation of gaging-station records: U.S. Geol. Survey Water-Supply Paper 1541-C, 100 p.

Speer, P. R., 1960, Lowest mean discharge and flow duration data by years at selected gaging stations in the Mississippi embayment area: U.S. Geol. Survey open-file report, $666 \mathrm{p}$.

Stiff, H. A., Jr., 1951, The interpretation of chemical water unalysis by means of patterns: Jour. Petroleum Technology, Oct., p. 15.

Tennessee Valley Authority, Division of Water Control Planning and Division of Forestry Development, 1955 and 1958, Daily gage heights and discharges at TVA stream gages in the Tennessee River basin, two volumes: Repts. 0-5794, 424 p., and 0-5794-A, 93 p.

1962, Influence of reforestation and erosion control upon the hydrology of the Pine Tree Branch watershed, 1941 to 1960: $98 \mathrm{p}$.

U.S. Army Corps of Engineers, Mississippi River Commission [no date], Results of discharge observations, Mississippi River and its tributaries and outlets (1838-1923, 1931-33, 1941, 1942).

[no date], Stages of the Mississippi River and of its principal tributaries (1927-37, 1940-42).

- [no date], Daily discharge of Mississippi River and its tributaries and outlets (1928-36, 1942).

- [no date], Stages and discharge observations, lower valley of the Mississippi River, January 1 to June 30, 1937: Mississippi River Commission Print 10-37, 53 p.

- [no date], Stages and discharges, Mississippi River and its outlets and tributaries (1943-56).

- [no date], Annual maximum, minimum, and mean dis- charges of the Mississippi River and its outlets and tributaries to 1953: $140 \mathrm{p}$.

- [no date], Annual highest and lowest stages of the Mississippi River and its outlets and tributaries to 1960: $266 \mathrm{p}$.

U.S. Army Corps of Engineers, New Orleans District [no date], Stages of the Mississippi River and tributaries and other streams and waterways in the New Orleans District (1946$50)$.

- [no date], Stages and discharges of the Mississippi River and tributaries and other streams and waterways in the New Orleans District (1951-56).

U.S. Army Corps of Engineers, Vicksburg District [no date], Stages of the Mississippi River and tributaries in the Vicksburg District (1933, 1940, 1944-46).

- [no date], Stages and discharges of the Mississippi River and tributaries in the Vicksburg District (1947-56).

- 1 January 1959, Water resources de velopment by the U.S. Army Corps of Engineers in Mississippi.

U.S. Congress, House of Representatives, Interior and Insular Affairs Committee, 1952, The physical and economic foundation of natural resources, pt. 3 , Groundwater region of the United States-their storage facilities: $78 \mathrm{p}$.

U.S. Geological Survey, 1948, North Mississippi floods of February 1948: Mississippi Geol. Survey Bull. 66, 55 p.

- 1950, Surface waters of Mississippi: Mississippi Geol. Survey Bull. 68,338 p.

- 1951a, Surface water supply of the United States, 1951, Part 2-B, South Atlantic slope and eastern Gulf of Mexico basins, Ogeechee River to Pearl River: U.S. Geol. Survey Water-Supply Paper 1204, 350 p.

- 1951b, Surface water supply of the United States, 1951, Part 3-B, Cumberland and Tennessee River basins: U.S. Geol. Survey Water-Supply Paper 1206, 252 p.

- 1951c, Surface water supply of the United States, 1951, Part 7, Lower Mississippi River basin: U.S. Geol. Survey Water-Supply Paper 1211, 484 p.

- 1953a, Floods of March-April 1951 in Alabama and adjacent States: U.S. Geol. Survey Water-Supply Paper 1227-A, $134 \mathrm{p}$.

1953b, Rice irrigation potential of Bogue Phalia, Mississippi: U.S. Geol. Survey open-file report, $39 \mathrm{p}$.

1956, North Mississippi floods of March 1955: U.S. Geol. Survey open-file report, $41 \mathrm{p}$.

- 1959, Floods of April-June 1953 in Louisiana and adjacent States: U.S. Geol. Survey Water-Supply Paper 1320-C, p. 155-320.

U.S. Public Health Service, 1962, Drinking water standards, revised 1962: Public Health Service Pub. 956, 61 p. 
The U.S. Geological Survey Library has cataloged this publication as follows:

\section{Speer, Paul Rudolph, 1904-}

Low-flow characteristics of streams in the Mississippi embayment in Mississippi and Alabama, by Paul R. Speer and others. With a section on Quality of the water, by W. J. Welborne. Washington, U.S. Govt. Print. Off., 1964.

iv, 47 p. maps ( 3 fold. col. in pocket) diagrs., tables. $30 \mathrm{~cm}$. (U.S. Geological Survey. Professional Paper 448-I)

Water resources of the Mississippi embayment.

Bibliography : p. 46-47.

(Continued on next card)

Speer, Paul Rudolph, 1904-

Low-flow characteristics of streams in the Mississippi embayment in Mississippi and Alabama. 1964. (Card 2)

1. Water-supply-Mississippi embayment region. 2. Water, Underground-Mississippi embayment region. 3. Stream measurementsMississippi embayment region. 4. Water-Composition.

I. Welborne, William J $1910-\quad$ II. Title. (Series) 